КАЗАХСКО-РУССКИЙ МЕЖДУНАРОДНЫЙ УНИВЕРСИТЕТ

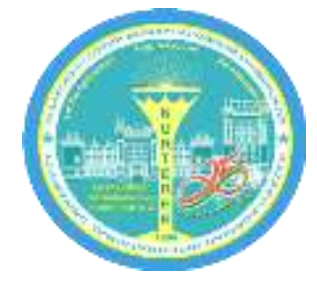

Капанова А.Т, Имангазин М.К

\title{
МИНЕРАЛЬНОЕ СТРОИТЕЛЬНОЕ СЫРЬЕ КАЗАХСТАНА
}

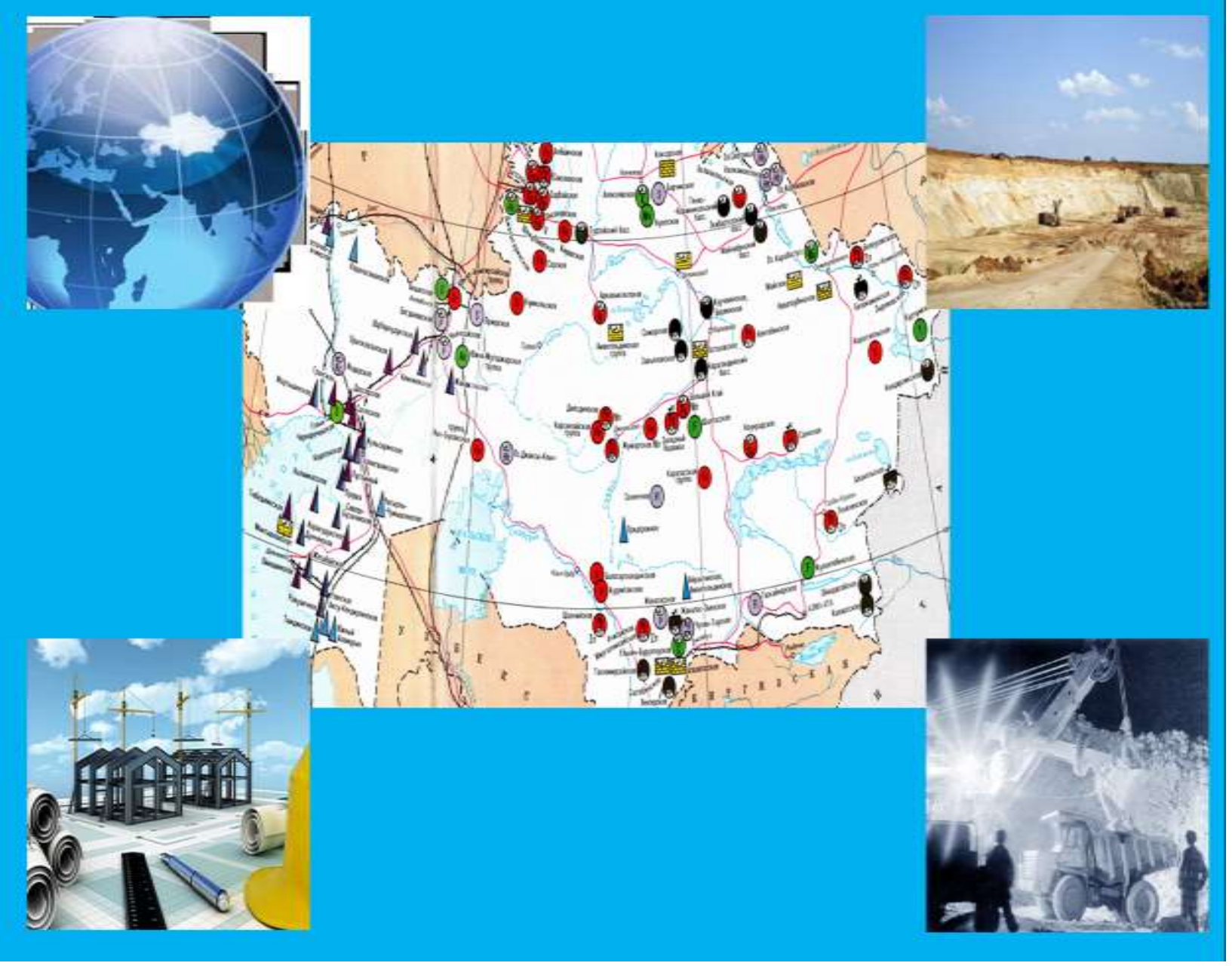

Актобе-2019 


\section{ББК 38.3}

ISBN 978-601-7965-49-5

\section{Составители: Капанова А.Т, Имангазин М.К «Минеральное строительное сырье Казахстана» для обучающихся по специальности 5В072900 - «Строительство». КРМУ, 2019. 120 с.}

Нурпеисова М.Б. д.техн.н., профессор. КазНТУ им.К.Сатпаева Утепов Е.Б,. д.техн.н., профессор. КазНТУ им.К.Сатпаева Ахметжан С.3. к.т.н., доцент. Казахско-Русского Международного университета

Рекомендовано Ученым Советом КРМУ в качестве учебного пособия по дисциплине «Минеральное строительное сырье Казахстана» для специальности 5В072900 «Строительство» /протокол №9 от 29 марта 2019Г/. ISBN 978-6017965-49-5

Курс «Минеральное строительное сырье Казахстана» входит в вузовский компонент учебного плана специальности 5В072900 «Строительство».

Пособие ориентировано на активное овладение студентами навыков самостоятельной работы, когда опыта рационального и эффективного изучения учебного материала у них еще мало.

По мнению специалистов, данное пособие содержательное, последовательное и прекрасно наполненное руководство, которое могут использовать преподаватели ВУЗов, бакалавры п практической деятельности.

Поэтому рецензируемое пособие следует считать весьма своевременным и актуальным.

Настоящее пособие, безусловно, поможет студентам в успешном изучении курса «Минеральное строительное сырье Казахстана». 


\section{СОДЕРЖАНИЕ}

\begin{tabular}{|c|c|c|}
\hline & ВВЕДЕНИЕ & 5 \\
\hline 1 & Минеральное сырье и строительные материалы & 9 \\
\hline 1.1 & Общие сведения о строительных материалах & 9 \\
\hline 1.2 & Минеральное сырье, классификация & 10 \\
\hline 1.3 & Геологические процессы и горные породы & 12 \\
\hline 1.3 .1 & Магматические горные породы & 15 \\
\hline 1.3 .2 & Метаморфические горные породы & 17 \\
\hline 1.3 .3 & Классификация метаморфических горных пород & 22 \\
\hline 1.3 .4 & Осадочные горные породы & 25 \\
\hline 1.3 .5 & Классификация осадочных горных пород & 27 \\
\hline 1.3 .6 & Обломочные породы & 29 \\
\hline 1.3.7 & Глинистые породы & 31 \\
\hline 1.3 .8 & Химико-органогенные породы & 32 \\
\hline 1.4 & $\begin{array}{l}\text { Сырье с промышленно ценным химическим составом. Гипс } \\
\text { и ангидрит }\end{array}$ & 35 \\
\hline 1.5 & $\begin{array}{l}\text { Сырье с промышленно ценными свойствами и составом. } \\
\text { Глинистые породы }\end{array}$ & 39 \\
\hline 1.6 & Сырье для производства пористых заполнителей & 44 \\
\hline 1.7 & Вулканогенно-обломочные породы & 45 \\
\hline 2 & Техногенное сырье & 51 \\
\hline 2.1 & Техногенные минеральные ресурсы & 51 \\
\hline 2.2 & Использование техногенного сырья в строительстве & 55 \\
\hline 2.3 & Вторичное минеральное сырье и его характеристика & 62 \\
\hline 2.4 & $\begin{array}{l}\text { Значение вторичного сырья для производства строительных } \\
\text { материалов } \quad \text { и экологии }\end{array}$ & 63 \\
\hline 3 & Минеральное сырье для производства цемента & 65 \\
\hline 3.1 & Карбонатные породы & 66 \\
\hline 3.2 & Глинистые породы & 66 \\
\hline 3.3 & Кремнистые кристобалит-опаловые породы & 67 \\
\hline 3.4 & Сульфатные породы & 68 \\
\hline 4 & Сырье для производства минеральных вяжущих веществ & 71 \\
\hline 5 & Минеральные пигменты & 74 \\
\hline 6 & Нерудные природные строительные материалы & 78 \\
\hline 7 & Природное дорожно-строительное сырье & 81 \\
\hline 8 & Песчаные породы & 84 \\
\hline 8.1 & Общая характеристика рыхлых пород. Песок & 87 \\
\hline 9 & Битумы & 91 \\
\hline 10 & Природные камни в строительстве & 93 \\
\hline 11 & Промышленность строительных материалов Казахстана & 96 \\
\hline
\end{tabular}




\begin{tabular}{|l|l|c|}
\hline 12 & $\begin{array}{l}\text { Экологические проблемы добычи минерального } \\
\text { строительного сырья и производства строительных } \\
\text { материалов }\end{array}$ & 98 \\
\hline $\mathbf{1 3}$ & Строительное сырье Актюбинской области & 101 \\
\hline & ЗАКЛЮЧЕНИЕ & 104 \\
\hline & Вопросы для самопроверки & 107 \\
\hline & Терминология & 108 \\
\hline & Тестовые вопросы & 109 \\
\hline & Список литературы & 115 \\
\hline & Приложения & 116 \\
\hline
\end{tabular}




\section{ВВЕДЕНИЕ}

Природные строительные материалы, получаемые в результате относительно несложной механической обработки монолитных горных пород с сохранением их физико-механических и технологических свойств, используются в виде плит, блоков, бортовых и облицовочных камней, дорожной брусчатки, бутового камня, щебня, дробленого песка и т. д. В огромных количествах используются также естественные рыхлые породы: валуны, гравий, песок, глина и др. Кроме того, горные породы являются важнейшими сырьевыми продуктами при получении искусственных строительных материалов (строительной керамики, огнеупоров, стекла, цемента, извести и др.). Для чего они подвергаются сложным видам механической и химической переработки.

Широкое использование природного сырья связано с наличием благоприятных физико-химических свойств многочисленных пород. Уже в ранний период своего существования человек обнаружил на поверхности земли и в еe недрах множество природных материалов, которые полностью удовлетворяли его сравнительно ограниченные потребности. На последующих стадиях развития человеческого общества появляются повышенные требования к качеству строительного камня и одновременно усложняются способы обработки и переработки природного сырья для получения материалов иного качества и свойств, например превращения обычной глины в камень при ее обжиге и получения стабильных свойств готового продукта.

Крупной составляющей современной экономики любой страны выступает промышленность строительных материалов, изделий и конструкций. Являясь основной материальной базой для строительства, она существенно влияет на темпы роста в других отраслях экономики и социальное состояние общества в целом. В Казахстане, в состав промышленности строительных материалов входят около 600 предприятий, при этом лишь 30 из них являются крупными, а 100 - средними. Всего в стройиндустрии Казахстана занято 268 тыс. человек (4 \% от общего числа занятых), из них в отрасли производства строительных материалов 63753 человек. В большинстве развитых стран доля стройиндустрии в общей занятости варьируется от 5 до $7 \%$.

Тенденции в промышленности строительных материалов определяются, прежде всего, мерой инвестиционной активности в экономике республики, 
темпами реформирования отраслей и изменением структуры капитальных вложений.

Мониторинг минерально-сырьевой базы Казахстана свидетельствует о наличии достаточного количества эксплуатируемых месторождений основных видов сырья для производства строительных материалов, изделий и конструкций, в том числе и для продукции высокой степени переработки, соответствующих современным требованиям строительного комплекса. Однако количество резервных, не вовлеченных в разработку месторождений по сравнению с эксплуатируемыми в настоящее время превалирует, что свидетельствует о недостаточном использовании сырьевой базы и создает предпосылки для ее экстенсивного развития.

Таблица 1 - Минерально-сырьевая база Казахстана для производства строительных материалов, изделий и конструкций.

\begin{tabular}{|c|c|c|c|c|}
\hline \multirow[t]{2}{*}{ № } & \multirow[t]{2}{*}{ Сырьевые материалы } & \multicolumn{3}{|c|}{$\begin{array}{l}\text { Запасы (включая балансовые и забалансовые), тыс. } \\
\text { куб.м }\end{array}$} \\
\hline & & Всего, в т.ч. & $\begin{array}{l}\text { эксплуати- } \\
\text { руемые }\end{array}$ & резервные \\
\hline 1 & Строительный камень & 3576239,5 & 1656557,3 & 1919682,2 \\
\hline 2 & Строительный песок & 1654088,4 & 68199,32 & 968889,1 \\
\hline 3 & Облицовочный камень & 86382,24 & 45971,51 & 40410,73 \\
\hline 4 & Гипс и ангидрит & 271282,0 & 175757,0 & 92525,0 \\
\hline 5 & Глины тугоплавкие & 71724,04 & 18227,04 & 53497,0 \\
\hline 6 & Перлитовое сырье & 471627,4 & - & 22531,4 \\
\hline 7 & $\begin{array}{l}\text { Волластонит и полевой } \\
\text { шпат }\end{array}$ & 471617,4 & 3944,2 & 467673,2 \\
\hline 8 & Цементное сырье & 4813236,3 & 2369902,3 & \\
\hline 9 & Асбест & 1514695,1 & 696838,0 & 817857,1 \\
\hline 10 & Песчано-гравийная смесь & 2596091,7 & 870185,3 & 1725906,4 \\
\hline 11 & Кирпичное сырье & 1310637,5 & 272430,4 & 1038207,1 \\
\hline
\end{tabular}

На сегодняшний день отечественная промышленность строительных материалов способна удовлетворять лишь часть потребностей строительного комплекса Казахстана, и как следствие существенную долю на рынке занимает импортная продукция, не допуская дефицита практически по всем видам строительных материалов. Несмотря на то, что в последние годы в Казахстане появились производства по выпуску керамической плитки, пластмассовых труб, металлочерепицы, столярных изделий из пластика, сухих смесей и другой продукции, практически вся продукция отрасли стройматериалов Казахстана неконкурентоспособна на внешнем рынке (за исключением асбеста).

Экономически выгодным и вполне реальным для Казахстана в перспективе станет экспорт новых строительных технологий в другие страны со всей 
сопутствующей документацией комплектной поставкой оборудования, а также с обучением местных кадров.

Новые технологии и материалы широко применяются в отделочных и инженерных работах, связанных с монтажом и ремонтом электрооборудования, водопроводов, отопительных систем, канализации, наружных сетей.

С каждым годом отмечается рост потребности в таких строительных материалах, как цемент, стекло, битум, деревянные изделия, стеновые и нерудные материалы, металлоконструкции и металлоизделия, теплоизоляционные и лакокрасочные материалы, сухие строительные смеси, природный камень, керамическая плитка, кровельные материалы, напольные покрытия.

Казахстан располагает богатыми сырьевыми возможностями для развития асбестоперерабатывающей, керамической, фарфорофаянсовой, керамзитовой, цементной, стекольной промышленности, а также развития производства извести, красок, теплоизоляционных материалов и т.д. Месторождения карбонатного сырья распространены по всей территории республики, их общие балансовые запасы превышают 3 миллиарда тонн. Государственным балансом учтены 8 месторождений известняка, пригодного для стекольной промышленности, общие его запасы по промышленным категориям составляют 15,2 миллиона тонн. Известняка, пригодного для выжига извести в республике, значительно больше, его суммарные запасы составляют 480,2 миллиона тонн. Разведано также 13 месторождений мела с совокупными запасами в 136,14 миллиона тонн. Его используют при производстве цемента и строительной извести. Казахстан отличается широким распространением кремнеземистых пород (опоки, диатомиты, трепелы), которые используются преимущественно для производства высококачественных цементов. Государственным балансом учтены 29 месторождений бентонитовых глин, пригодных для использования в керамической, фарфорофаянсовой и стекольной промышленности. Их запасы по всем промышленным категориям превышают один миллиард тонн. Разведанные запасы основных месторождений стекольных песков составляют около 40 миллионов тонн. На территории Казахстана выявлено 429 месторождений нерудных материалов, пригодных для производства стенового камня, кирпичных блоков, облицовочных плит, микрокальцита, щебня, мраморной крошки, бутового камня.

В Казахстане данная отрасль не отличается особой разветвленностью, многие товары, такие как санитарно-технические изделия, стекло листовое, многие виды лакокрасочных изделий, теплоизоляционных изделий и прочие не выпускаются отечественными производителями. 
Низкими темпами осуществляется перевооружение предприятий по производству цемента, теплоизоляционных, стеновых, кровельных отделочных материалов и других изделий. Не развито собственное машиностроение, практически нет заводов по производству грузоподъемных машин, подъемнотранспортных механизмов, строительных машин и технологического оборудования.

В этих условиях возрастает роль государства, обеспечивающая механизмы модернизации и развития промышленности строительных материалов.

В Республике Казахстан принята Программа развития промышленности строительных материалов, изделий и конструкций в Республике Казахстан, ее разработка обусловлена тем, что одним из основных направлений стратегического развития Казахстана является экономический рост на основе эффективного использования научно-технического потенциала республики и поэтапного замещения в валовом национальном продукте сырьевой составляющей на высокотехнологическую экспортоориентированную продукцию.

Целью Программы является обеспечение инновационного развития промышленности строительных материалов, изделий и конструкций Республики Казахстан. 


\section{1. МИНЕРАЛЬНОЕ СЫРЬЕ И СТРОИТЕЛЬНЫЕ МАТЕРИАЛЫ}

\section{1 Общие сведения о строительных материалах}

Строительными материалами называют природные и искусственные материалы, применяемые при возведении и ремонте различных сооружений и зданий. Затраты на материалы при этом составляют более половины общей стоимости строительно-монтажных работ.

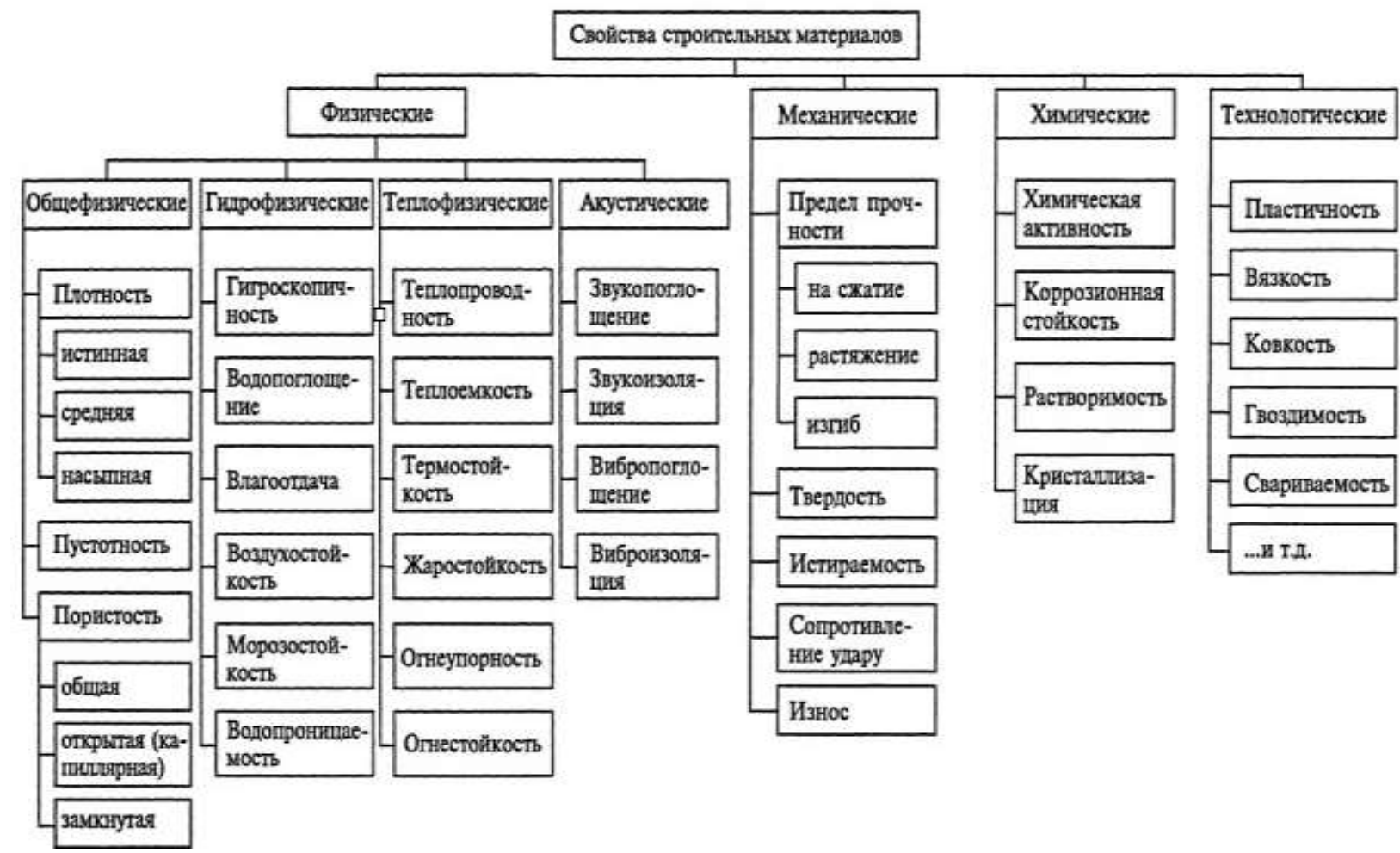

Рисунок 1. Общие сведения о строительных материалах

Строительные материалы классифицируют по следующим основным признакам:

\section{1.По составу:}

а) минеральные - нерудные горные породы и металлы - обладают высокой плотностью, прочностью, морозостойкостью, огнестойкостью, химической и биологической стойкостью; более теплопроводны, чем органические; применяют для конструкционных элементов; 
б) органические - древесина, рубероид, пергамин, битумы - имеют малую объемную массу (плотность), прочность, теплопроводность, огнестойкость и биостойкость (быстро гниют), легко обрабатываются; используются в качестве теплоизоляционных, отделочных, кровельных материалов, для работы в условиях невысоких температур и влажности.

\section{2.По виду исходного сырья и способу получения:}

a) природные (каменные) - горные нерудные ископаемые породы подразделяются на 3 группы: изверженные (гранит, базальт, пемза), осадочные (песок, глина, гипс, известняк) и метаморфические (мрамор, кварцит, гнейс);

б) безобжиговые - растворы и бетоны- получают в результате естественного затвердевания смеси из вяжущего вещества (цемент и др.), заполнителей (песок, гравий и др.) и воды;

в) керамические или обжиговые - черепица, кирпич красный - получают в результате обжига глины с добавками;

г) металлические - арматура, каркасы металлоконструкций (в основном из стали и чугуна);

д) полимерные - на основе пластмасс и синтетических смол;

е) из древесины- полы, двери, оконные рамы, кровля, отделка;

ж) стеклянные - для внешнего и внутреннего оформления зданий, для заполнения проемов (окна, витражи), для отделочных работ (мозаика и др.);

з) на основе битума, дегтя и бумаги ( рубероид, пергамин, картон).

\section{3.По назначению:}

a) конструкционные (балки, брѐвна, брус, плиты);

б) вяжущие (портландцемент, известь, гипс);

в) стеновые (кирпич, панели бетонные и железобетонные);

г) отделочные, тепло- и звукоизолячионные;

д) для полов (доска, паркет, ламинат, линолеум, плитка и др.);

е) для остекления (стеклопакеты, стеклоблоки);

ж) санитарно-технические.

\section{2 Минеральное сырье, классификация}

Минеральное сырье - это товарная продукция горнодобывающего предприятия, что является результатом его хозяйственной деятельности по добыче полезных ископаемых, в том числе путем выполнения хозяйственных договоров об услугах по давальческому сырью, и по качественным характеристикам отвечает требованиям установленных законодательством стандартов или требованиям договоров. Не относятся к минеральному сырью вещества, которые возникают в результате физико-химической переработки 
добытого полезного ископаемого или продуктов его первичной переработки По признаку использования в народном хозяйстве минеральное сырье классифицируется следующим образом:

- твердое топливно-химическое сырье,

- жидкое и газообразное топливно-химическое сырье,

- металлические руды,

- нерудное сырье для металлургии,

- группа технического сырья, драгоченных и поделочных камней,

- сырье для строительной индустрии,

- горнохимическое сырье,

- подземные воды.

Наиболее приемлемо разделение минерального сырья всех видов, включая металлические и горючие полезные ископаемые, на три группы:

- элементы и их соединения;

- минераль,

- горные породы.

К неметаллическим полезным ископаемым относятся такие минералы и горные породы, которые не являются источником металлов и не представляют минерального топлива.

Рудное неметаллическое сырье - минеральные агрегаты, из которых в процессе переработки извлекают элементы, их соединения или минералы (например, руды асбестовые, алмазные, борные, калийные).

К нерудному неметаллическому сырью относят глины, гравийнопесчаные смеси и другие промышленные горные породы.

Некоторые горные породы используют не целиком, а извлекают из них в процессе переработки наиболее ценные компоненты (например, блоки строительного и облицовочного камня). Такие виды сырья относят к полурудным.

С учетом этого положения в первой группе неметаллических полезных ископаемых (сырье для извлечения элементов и их соединений) выделяются два класса:

- туковое и химическое сырье (сера, фосфор, калий, хлор, натрий, азот и др.);

- индустриальное и химическое сырье (бор, селен, мышьяк, стронщий, магний, инертные газы, кислород). Месторождения сырья первой группы по особенностям разведки и оценки очень близки к месторождениям металлов.

Во второй группе неметаллических полезных ископаемых (сырье для извлечения промышленных минералов) выделяются три подгруппы:

- сырье с промышленно ценным химическим составом (полевые шпаты, высокоглиноземистое сырье, магнезит); 
- сырье с промышленно цуенными физическими свойствами и химическим составом (тальк, пирофиллит, волластонит, каолинит и др.);

- сырье с промышленно цуенными физическими свойствами. Сырье последней подгруппы разделяется на кристалль и минеральные агрегаты $u$ аморфные веществв.

Среди кристаллических видов сырья выделяются классы:

- индустриальное сырье (слюда, асбест, исландский ипат);

- камнесамоцветно-индустриальное сырье (алмаз, благородные корунд, берилл, шпинель, пьезоквари и оптический квари, турмалин и др.);

- камнесамоцветное сырье (благородные гранаты, диопсид, сподумен, хризоберилл, эвклаз, топаз и др.).

Сырье, представленное минеральными агрегатами и аморфными веществами, также разделяется на три класса:

- индустриальное (графит, корунд, ичеолить);

- индустриально-камнесамоцветное (агат, янтарь, малахит);

- камнесамочзетное (бирюза, благородный опал, хризопраз и др.).

В третьей группе неметаллических полезных ископаемых (промышленные горные породы) также выделяются три подгруппы:

- сырье с промышленно цуенным химическим составом (гипс и ангидрит);

- сырье с промышленно цуенными физическими свойствами и химическим составом (глинистые, кремнистые, карбонатные, изверженные, метаморфические и другие породы); - сырье с промышленно ценными физическими свойствами. Сырье с промышленно ценными физическими свойствами (последней подгруппы) разделяется на классы:

- индустриально-камнесамоцьетное сырье (минеральные пигменты, обсидиан, ящмй);

-камнесамоцветное сырье (гагат, жадеитит, нефрит и др.);

- облицовочные материаль (мраморный оникс, орлец, серпентинит и др.).

\section{3 Геологические процессы и горные породы}

Земная кора сложена из различных минеральных агрегатов, которые встречаются не по одиночке, а в сообществах, постоянно повторяющихся в самых разных пунктах земного шара и разных глубинах земной коры. Устойчивость таких сообществ подчёркивает их характер.

Совместное нахождение минералов, обусловленное общностью их происхождения, называется парагенезом (пара, возле, генезис - образование, 
происхождение). Наиболее распространёнными и устойчивыми формами парагенетических ассоциаций, сообществ минералов являются горные породы.

В составе горных пород различают породообразующие минераль, составляющие основную массу горных пород и минералы акцессорные, m. e. дополнительные, доля которых может быть ничтожно мала, но они являются характерной примесью для отдельных разновидностей.

Горными породами являются такие естественные парагенетические сообщества минералов, которые образуют самостоятельные геологические тела.

Геологическая самостоятельность горных пород состоит в том, что горные породы:

- своим происхождением обязаны геологическим процессам общеземного планетарного значения;

- представляют собой крупные, обособленные в пространстве минеральные тела, составляющие в своей массе существенную часть земной коры.

Геологические процессы, приводящие к образованию горных пород, называются процессами породообразования или петрогенеза .

К ним относятся: магматизм, метаморфизм горных пород и осадконакопление (седиментация). В зависимости от зоны образования различают три генетических типа пород, По признаку происхождения (генезиса) все горные породы подразделяются на:

- магматические (гранит, диорит);

- метаморфические (кристаллические сланцы, гнейсы);

- осадочные (известняки, глины, пески и песчаники).

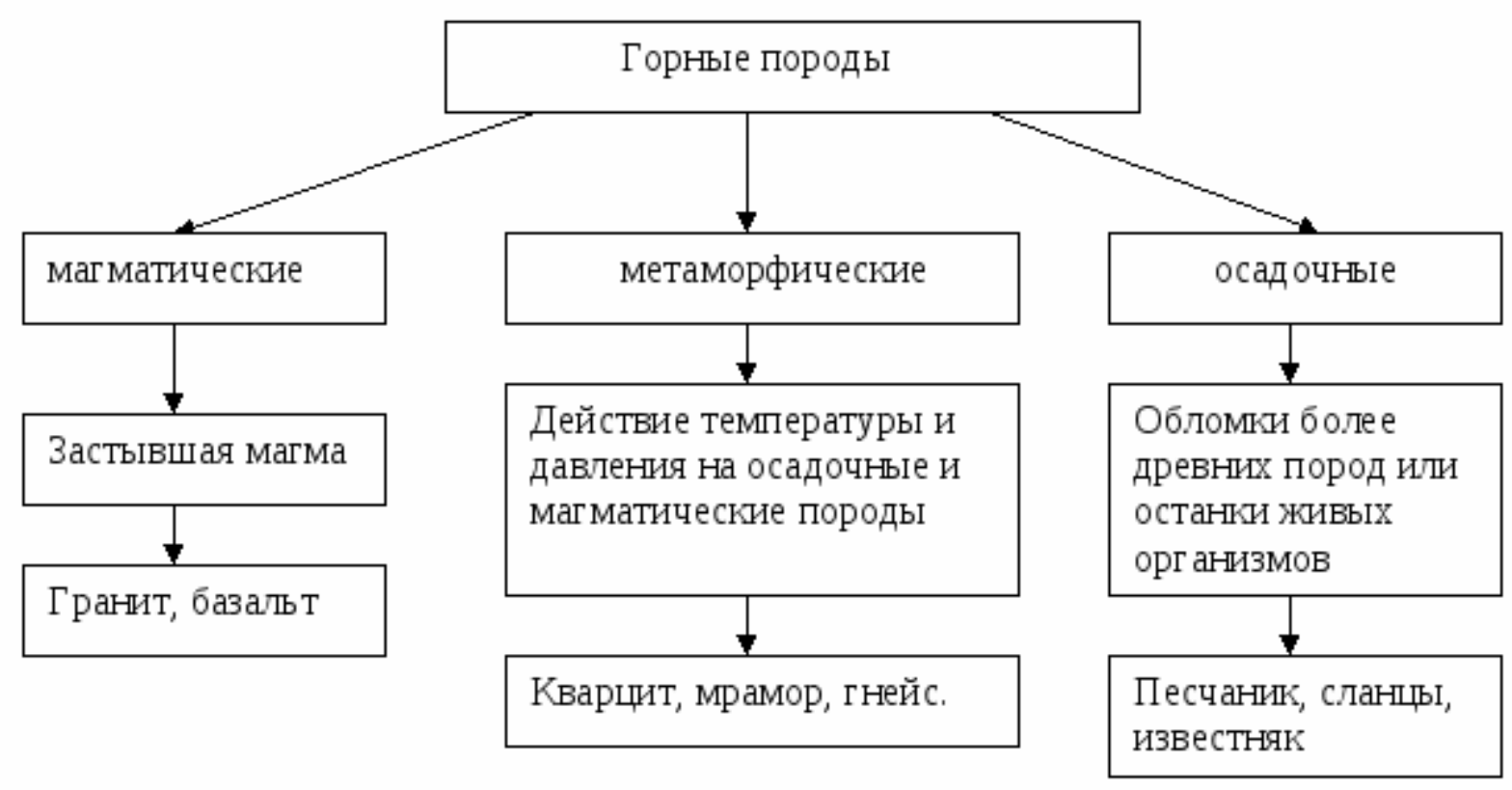

Рисунок 2. Горные породы и классификация 
Горные породы могут состоять из одного минерального вида (каменная соль), называются мономинеральной и нескольких, т.е. полиминеральной, к которым относится большинство горных пород.

Горные породы отличаются друг от друга не только по минеральному составу и происхождению, но и по строению (структуре), сложению (текстуре) и формам залегания в земной коре.

Строение горных пород (структура) определяется размерами, формой $u$ взаимным расположением минеральных зёрен, агрегатов минералов, включений, а также способом связей между минеральными составляющими:

- простое соприкосновение минеральных зёрен (пески).

- сцементированы цементирующим веществом (песчаники - сцементированы карбонатом, гипсом, глинами);

- минеральные зёрна «спаяны» друг с другом (гранит, мрамор);

- минеральные зёрна могут быть заключены в стекловатую массу.

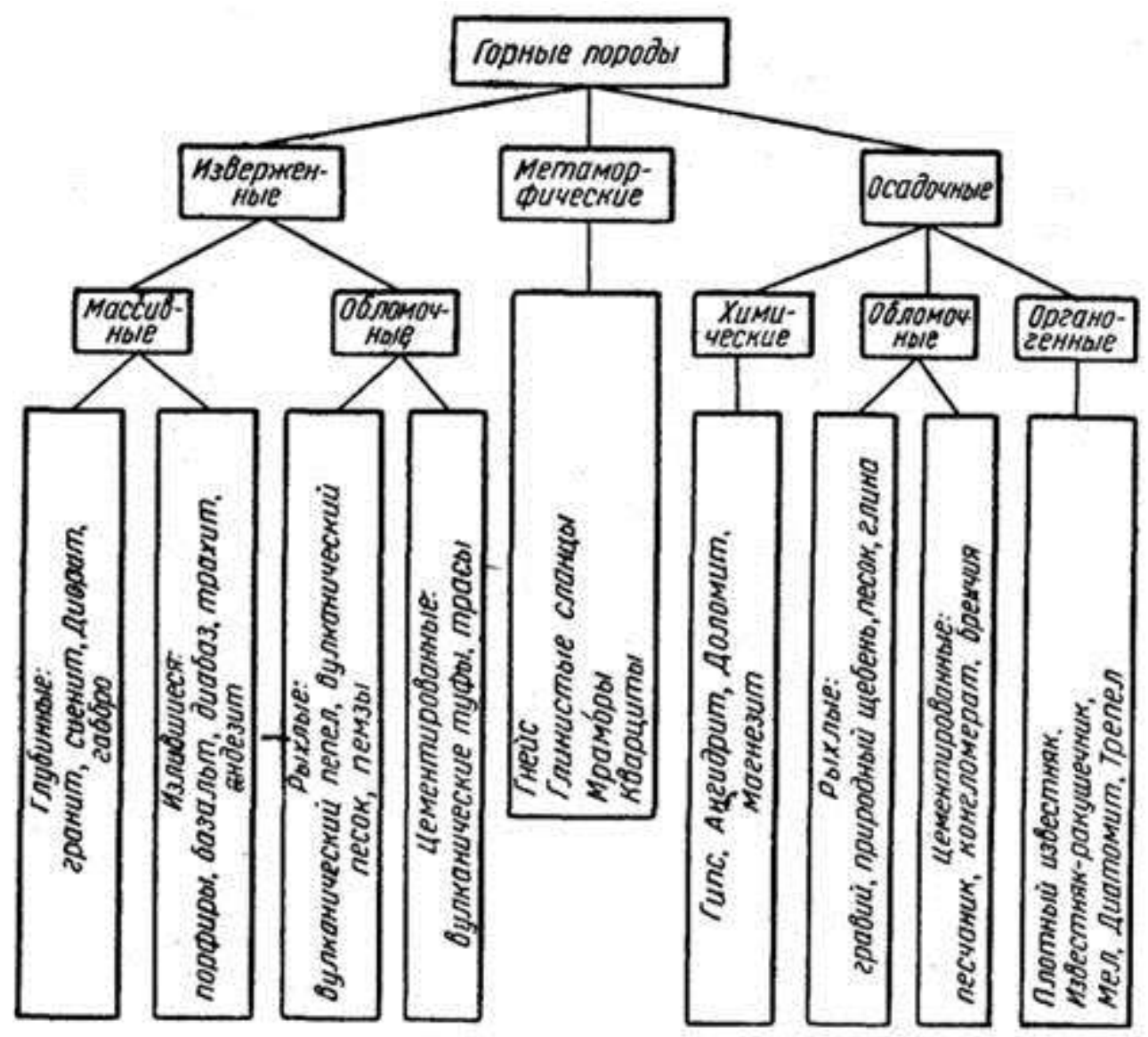

Рисунок 3. Классификация и виды горных пород, применяемых в строительстве

Сложение горных пород (текстура - это способ строения, выраженный пространственным взаиморасположением минеральных масс, составляющих горную породу.

Для осадочных горных пород характерно слоистое сложение, когда минеральные массы распределены в горной породе слоями. 
Для магматических горных пород большей частью свойственно массивное сложение, возникающее вследствие равномерного остывания и кристаллизации масс на глубине. При изливании магматических пород на поверхность образуются серии покровов пузырчатого, шлакового и других сложений.

Для метаморфических горных пород характерно сланцевое сложение, когда горная порода легко расчленяется по плоскостям, т. е. образуются плоскости сланцеватости.

Формы залегания горных пород весьма различны. Форма залегания осадочных пород представлена слоями или серией слоёв, образующими толщу слоистого сложения.

Магматические породы, изливающиеся на поверхность Земли, залегают в виде растекающихся потоков (по лощинам и долинам) или покровов (покрывающих обширные пространства). Магматические массы, застывающие на глубине, образуют жилы, дайки, батолиты, лакколиты и другие типы минеральных тел.

Метаморфические породы сохраняют формы залегания первичных материнских горных пород, в результате изменения (метаморфизма) которых они образовались.

Перечисленные петрографические характеристики горных пород в существенной мере зависят от условий породообразования, которые называются фациальнылми условиями (фация - обмен) и применяются для всех пород (фация - употреблялась для обозначения физико-географических образований осадочных пород).

\subsection{1 Магматические горные породы}

Магматические горные породы образуются из огненно-жидких силикатных расплавов (магма), в той или иной мере насыщенных газами и парами, в результате кристаллизации магмы при её остывании в недрах Земли или на её поверхности. Магма, излившаяся на поверхность и освободившаяся от части газов и воды, превращается в лаву. Магма представляет собой сложный силикатный расплав примерно следующего состава: кислород $-46,7 \%$, кремний $-27,7 \%$, алюминий $-8,1 \%$, железо $-5,1 \%$, кальций $-3,6 \%$, магний $-2,1 \%$, натрий $-2,7 \%$, калий $-2,6 \%$, доля остальных элементов не превышает $1,4 \%$. Температура магмы различна и составляет $100 \ldots 1300^{\circ} \mathrm{C}$.

Магматические горные породы возникают при остывании и отвердении магмы и лавы. При медленном остывании магмы на значительных от поверхности глубинах отвердение магматического расплава происходит путём образования и роста кристаллов, т. е. идёт процесс кристаллизации. 
При этом возникают магматические горные породы полнокристаллического строения, называемые глубинными или интрузивными. При быстром остывании магмы, излившейся на поверхность, кристаллизация не поспевает за остыванием и магма превращается в горные породы неполно кристаллического, стекловатого или скрыто кристаллического строения - излившиеся или эффузивные породы.

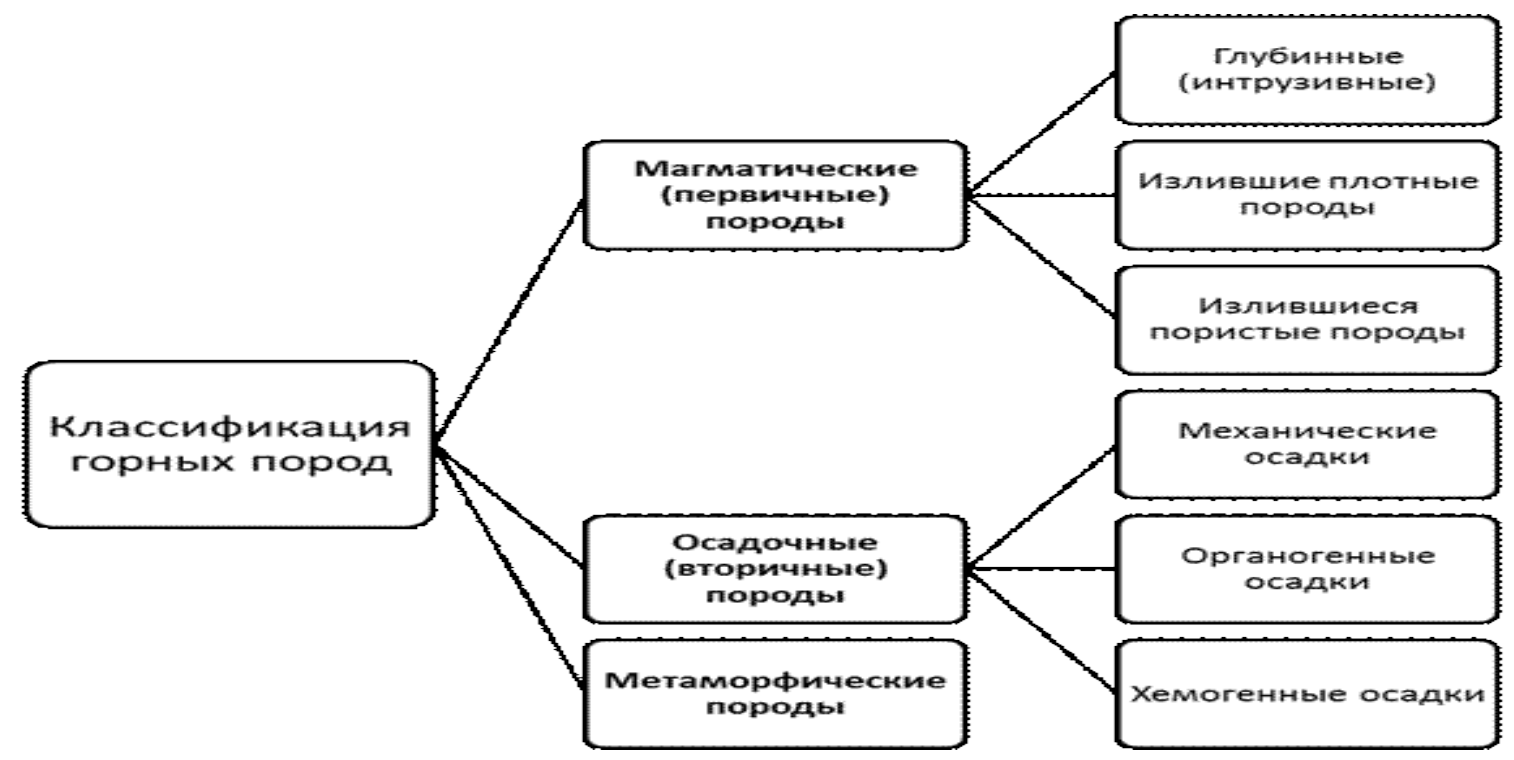

Рисунок 4. Классификация горных пород. Магматические породы

Кроме зёрен в составе излившихся магматических пород встречается вулканическое стекло, возникшее при очень быстром охлаждении и затвердевании магматического расплава.

Главными породообразуюшчими минералами являются кварц, полевые шпаты, нефелин, минералы из группы слюд, амфиболов, пироксенов, оливин. Оливин, пироксен, слюды, амфиболы по своей окраске называются тёмноцветными; полевые шпаты, нефелин, кварц - светлыми. Минералы, содержащие в своём химическом составе щелочные элементы - $\mathrm{K}$, $\mathrm{Na}$ объединяются в щелочные группы, это калиевые полевые шпаты и альбит, щелочные пироксены и щелочные амфиболы, нефелин.

Таблица 2 - Классификация магматических пород по химическому составу

\begin{tabular}{|c|c|c|c|c|}
\hline $\begin{array}{l}\text { Состав } \\
\text { пород }\end{array}$ & Породы & $\begin{array}{l}\text { Преобладаю } \\
\text { щие цвета }\end{array}$ & $\begin{array}{l}\text { "Цветное } \\
\text { число, \% }\end{array}$ & Минералы-индикаторы \\
\hline $\begin{array}{l}\text { содержан } \\
\text { ие оксида } \\
\mathrm{SiO}_{2}, \%\end{array}$ & минералы & $\begin{array}{l}\text { интрузивные } \\
\text { (глубинные) }\end{array}$ & $\begin{array}{l}\text { эффузивны } \\
\text { е } \\
\text { (излившие } \\
\text { ся) }\end{array}$ & \\
\hline
\end{tabular}




\begin{tabular}{|c|c|c|c|c|c|c|c|}
\hline главные & $\begin{array}{l}\text { второстепенн } \\
\text { ые }\end{array}$ & & & & & & \\
\hline $\begin{array}{l}\text { Кислые } \\
(75-65 \% \\
\left.\mathrm{SiO}_{2}\right), \\
\text { плотност } \\
\text { ь 2,5-2,7 } \\
\text { (для глу- } \\
\text { бинных } \\
\text { пород) }\end{array}$ & $\begin{array}{l}\text { кварц, } \\
\text { калиевый } \\
\text { полевой } \\
\text { шпат, кислые } \\
\text { плагиоклазы, } \\
\text { биотит, } \\
\text { мусковит, } \\
\text { роговая } \\
\text { обманка, } \\
\text { пироксены }\end{array}$ & $\begin{array}{l}\text { апатит, } \\
\text { циркон, } \\
\text { магнетит, } \\
\text { турмалин }\end{array}$ & $\begin{array}{l}\text { гранит, } \\
\text { пегматит }\end{array}$ & $\begin{array}{l}\text { липарит, } \\
\text { обсидиан, } \\
\text { пемза }\end{array}$ & $\begin{array}{l}\text { светл } \\
\text { ые }\end{array}$ & $5 \ldots 15$ & кварц \\
\hline $\begin{array}{l}\text { Средние } \\
(52-65 \% \\
\left.\mathrm{SiO}_{2}\right), \\
\text { плотност } \\
\text { ь 2,7-2,9 } \\
\text { а) с } \\
\text { плагиокл } \\
\text { а-зами б) } \\
\text { с } \\
\text { калиевым } \\
\text { и } \\
\text { полевыми } \\
\text { шпатами }\end{array}$ & $\begin{array}{l}\text { средние } \\
\text { плагиоклазы, } \\
\text { роговая } \\
\text { обманка, } \\
\text { биотит, } \\
\text { пироксены } \\
\text { калиевый } \\
\text { полевой } \\
\text { шпат, } \\
\text { роговая } \\
\text { обманка, } \\
\text { кислые пла- } \\
\text { гиоклазы, } \\
\text { биотит, } \\
\text { пироксены }\end{array}$ & $\begin{array}{l}\text { кварц, } \\
\text { калиевый } \\
\text { полевой } \\
\text { шпат, апатит, } \\
\text { титанит, } \\
\text { магнетит } \\
\text { кварц, } \\
\text { титанит, } \\
\text { циркон }\end{array}$ & $\begin{array}{l}\text { диорит } \\
\text { сиенит }\end{array}$ & $\begin{array}{l}\text { андезит, } \\
\text { порфирит } \\
\text { трахит, } \\
\text { ортоклазов } \\
\text { ый порфир }\end{array}$ & серые & $\begin{array}{l}15 \ldots 2 \\
5\end{array}$ & $\begin{array}{l}\text { кварц } \\
(51 \%) \text { или } \\
\text { отсутствует }\end{array}$ \\
\hline $\begin{array}{l}\text { Основны } \\
\text { е (52-40\% } \\
\left.\mathrm{SiO}_{2}\right), \\
\text { плотност } \\
\text { ь 2,9-3,1 }\end{array}$ & $\begin{array}{l}\text { основные } \\
\text { плагиоклазы, } \\
\text { пироксены } \\
\text { оливин, } \\
\text { роговая } \\
\text { обманка, } \\
\text { биотит }\end{array}$ & $\begin{array}{l}\text { ортоклаз, } \\
\text { кварц, апатит, } \\
\text { магнетит, } \\
\text { титанит }\end{array}$ & $\begin{array}{l}\text { габбро, } \\
\text { лабрадорит }\end{array}$ & $\begin{array}{l}\text { базальт, } \\
\text { диабаз }\end{array}$ & $\begin{array}{l}\text { чёрны } \\
\text { e }\end{array}$ & & $\begin{array}{l}\text { оливин } \\
\text { (присутству } \\
\text { ет в } \\
\text { незначител } \\
\text { ь ном } \\
\text { количестве) }\end{array}$ \\
\hline $\begin{array}{l}\text { Ультра- } \\
\text { основные } \\
(<40 \% \\
\left.\mathrm{SiO}_{2}\right), \\
\text { плотност } \\
\text { ь 3,1-3,4 }\end{array}$ & $\begin{array}{l}\text { оливин, } \\
\text { пироксены, } \\
\text { роговая } \\
\text { обманка }\end{array}$ & $\begin{array}{l}\text { магнетит, } \\
\text { ильменит, } \\
\text { хромит, } \\
\text { пирротин }\end{array}$ & $\begin{array}{l}\text { дунит, } \\
\text { перидотит } \\
\text { пироксени } \\
\text { т }\end{array}$ & & $\begin{array}{l}\text { чёрны } \\
\text { е или } \\
\text { тёмно- } \\
\text { зелён } \\
\text { ые }\end{array}$ & & $\begin{array}{l}\text { оливин } \\
\text { (присутству } \\
\text { ет в } \\
\text { значительн } \\
\text { ом } \\
\text { количестве) }\end{array}$ \\
\hline
\end{tabular}

* - цветное число определяет содержание в породе темноокрашенных минералов силикатов (пироксены, роговая обманка, биотит, оливин).

\subsection{2 Метаморфические горные породы}

Метаморфические горные породы - это глубоко изменённые в процессе метаморфизма первично-осадочные и магматические горные породы 
(«метаморфо» по-гречески - преобразуюсь, превращаюсь). При метаморфизме существенно изменяется минеральный состав пород, их структура и текстура. При этом порода сохраняет твёрдое состояние без расплавления или растворения. Процессы метаморфизма, сопровождающиеся переплавлением исходной породы с вмещающими породами или без них, приводят к образованию ультраметаморфических пород.

Главными факторами метаморфизма являются: высокая температура, источником которой могут быть как высокая температура недр Земли, так и поднимающиеся из этих недр расплавленные магмы; большое давление, как всестороннее (гидростатическое), увеличивающееся по мере опускания в глубь земной коры, так и направленное (стресс), связанное с тектоническими движениями; привнос в породу или вынос из нее химических веществ высокотемпературными растворами и газами. Воздействие температуры и давления связано с одновременным воздействием флюидов. Флюиды - это жидкие и газообразные компоненты магмы или циркулирующие в глубинах Земли насыщенные газами растворы. В их составе преобладают пары воды, хлора, углекислого газа и многих других элементов и соединений.

В зависимости от ведущего фактора выделяют следующие виды метаморфизма: катакластический, региональный, контактовый, термальный и динамотермальный.

Катакластический метаморфизм приурочен к участкам развития дизъюнктивных нарушений - дислокаций — типа сбросов, развит в их границах и совершается при сравнительно небольших давлениях и довольно низкой температуре. При этом происходит дробление крепких минералов или их деформации в первоначальной структуре и текстуре пород и, в результате происходит хрупкое разрушение минералов и их перемещение. Трещины в породе не возникают, происходит преобразование породы в результате пластических деформаций, при которых возможны химические изменения пород. Протекающие изменения приводят к формированию самых разнообразных пород - от гранитоидов до тектонических брекчий, катаклазитов и милонитов.

Региональный метаморфизм вызывается высокой температурой и большим гидростатическим давлением в глубинах Земли, когда крупные массивы горных пород земной коры погружаются на эти глубины. Сопровождается перекристаллизацией пород, образованием новых минералов и сланцеватой текстуры.

Контактовый метаморфизм происходит под действием высоких температур на контакте горных пород с очагами внедряющейся расплавленной магмы, т.е. осадочные и магматические горные породы попадают под 
воздействие магматических масс, внедрившихся в их толщу. При этом происходит изменение структуры и текстуры пород, а при выделении паров в растворы - и их состава. Образование контактово-метаморфических горных пород в зоне воздействия магматических расплавов может происходить с привносом веществ из этого расплава или без привноса. В этом случае различают собственно контактовый метаморфизм (без привноса) и контактовометасоматический (с привносом). Контактовым изменениям подвержены не только вмещающие породы, но и сами магматические массы, поэтому различают внешний (экзоконтактовый) и внутренний (эндоконтактовый) метаморфизм.

Динамометаморфизм наблюдается при действии направленного давления, связанного с тектоническими движениями земной коры, т.е. горные породы оказываются в зоне воздействия высоких тектонических напряжений земной коры. При этом может повышаться и температура.

При явлениях динамометаморфизма нередко наблюдается дробление, расслаивание и другие механические изменения, приводящие к образованию так называемых катаклазитов, возникающих в относительно узких зонах тектонических нарушений в виде сбросов и надвигов. Зерна минералов под действием давления интенсивно дробятся без существенной перекристаллизации.

Пневматолитовый и гидротермалъный метаморфизм связан с привносом в породу новых химических веществ газами и горючими водными растворами, поднимающимися из очага магмы. Они вызывают изменение химического и минералогического состава пород.

Динамотермальный метаморфизм дает самое большое разнообразие пород с очень широким их распространением в земной коре. В зависимости от условий протекания процесса различают региональный и локальный динамотермальный метаморфизм. Самостоятельным видом регионального динамотермального метаморфизма является ультраметаморфизм.

В каждом из этих видов метаморфизма сложный комплекс взаимодействия температур, стресса (разрядки напряжений), давления, иногда и флюидов приводят к формированию чрезвычайно широкого спектра метаморфических пород с весьма разнообразными физико-механическими свойствами.

В глубинных зонах складчатых областей в условиях ультраметаморфизма наблюдается переплавление ряда пород с образованием смешанных горных пород - мигматитов, имеющих разнообразную сложную структуру, что обусловливает весьма различную их прочность, неоднородность свойств, повышенную (по сравнению с другими, массивно-кристаллическими породами) выветриваемость. Для многих из них характерны слойчатость, послойные и секущие складки. 
При формировании термально-метаморфизованных пород главным фактором является температура магматического расплава. Под действием температуры на границах (контакте) интрузий образуются ореолы, сложенные особыми контактово-метаморфизованными породами. Мощность зоны контактовых изменений бывает различной и главным образом зависит от двух факторов: состава и состояния вмещающих пород, температуры, состава и продолжительности воздействия магмы. Наиболее типичными породами термального метаморфизма являются контактовые роговики, скарны, породы кремнистого состава.

Большое разнообразие метаморфических пород объясняется значительным разнообразием самих типов метаморфических процессов, условий их протекания и разнообразием состава и свойств самих магматических расплавов и вмещающих пород.

Метаморфические породы по внешнему виду и условиям залегания занимают промежуточное положение между магматическими и осадочными породами. По минеральному составу они ближе к магматическим породам.

Минеральный состав. Метаморфические породы состоят из устойчивых в условиях высокого давления и температуры минералов, что и магматические породы. К ним относятся минералы магматического происхождения: кварц, полевые шпаты, плагиоклазы, мусковит, биотит, роговая обманка, магнетит, гематит и минерал осадочного происхождения - кальцит. Кроме того, в метаморфические породы входят минералы метаморфического происхождения: графит, тальк, хлориты, гранаты, кианит, серицит, актинолит, эпидот, силлиманит, кордиерит, скаполит и др.

Структура. Все метаморфические породы имеют кристаллическое строение. Различают три типа структур: кристаллобластический; катакластический; реликтовый.

Кристаллобластическая структура образуется при одновременной перекристаллизации составных частей породы в твёрдом состоянии без переплавления.

По форме минеральных зёрен различают структуру листоватую, чешуйчатую, игольчатую и таблитчатую. По их взаимному расположению зёрен различают структуры: гранобластическую (равномернозернистую); роговиковую (зёрна имеют неправильное очертание); лепидобластическую (зёрна листоватой или пластинчатой формы); ориентированную (параллельно сланцеватости); столбчатую (развиты удлинённые призматические или столбчатые зёрна); порфиробластическую (отдельные минералы, обладая большей кристаллизационной силой, вырастают в крупные зёрна). По величине зерен 
различают крупнокристаллическую структуру (диаметр более 1мм), среднекристаллическую (0,25...1 мм) и мелкокристаллическую (менее 0,25мм);

Катакластические структуры возникают при тектоническом дроблении (катаклазе) горной породы и могут быть равномерно - или неравномерно катакластическими.

Реликтовые (иначе остаточные) структуры характеризуются сохранением элементов структуры материнских пород.

Текстуры (сложение) бывают реликтовые и метаморфические. В реликтовой структуре сохраняется структура материнской породы. Наиболее характерны следующие текстуры: сланцеватая (таблитчатые, листоватые, столбчатые и игольчатые кристаллы располагаются параллельно друг другу), полосчатая или ленточная (чередуются полосы разной толщины и различного минералогического состава). При сланцевой текстуре горная порода раскалывается по параллельным направлениям на тонкие пластинки. Выделяют: тонко,- и грубосланцевые текстуры. По степени проявления сланцевости различают совершенную и несовершенную сланцеватость. Встречаются породы с массивной текстурой, очковой и плойчатой (гофрированной). Массивной называется текстура зернистого строения без особой ориентировки минеральных зёрен.

Отдельности первично осадочных и магматических пород. Это реликтовые отдельности (унаследованные). Чаще всего в процессе метаморфизма появляются отдельности, характерные для этих пород, так называемые метаморфические отдельности. Они обусловлены системами параллельных трещин, не совпадающих с первичной текстурой породы, по которым порода легко раскалывается на отдельности. Такого рода системы трещчин называются кливажем.

Кливаж течения - возникает при пластическом деформировании породы под действием тектонических напряжений. При этом изменяется структура породы и образуется сланцеватость.

Кливаж разлома возникает при деформациях, т. е. крупных разрушениях. Минеральные зёрна сохраняют первоначальное положение, т.е. структура породы не изменяется.

Формы залегания метаморфических пород унаследованы от первично осадочных и магматических пород, кроме контактово-метаморфических пород залегающих в форме ореолов и зон вокруг магматических тел. Метаморфические породы, возникшие из глубинных магматических пород, более или менее сохраняют их первоначальную форму залегания. При метаморфизации осадочных пород слоистость сильно деформируется. При контактном метаморфизме образуются своеобразные оболочки метаморфических пород, 
окружающих магматические породы. Динамометаморфизм образует мощные зоны смятия, возникают сложные складки. При региональном метаморфизме измененные осадочные породы часто сохраняют первичную слоистость.

В процессе движения земной коры метаморфические породы могут быть выведены на дневную поверхность и являются почвообразующими породами.

\subsection{3 Классификация метаморфических горных пород}

Классификация метаморфических пород основана на структурных признаках и минеральном составе. Среди них выделяют породы: массивные (зернистые) - кварцит, мрамор; сланцеватые- гнейс и кристаллические сланцы различного минерального состава.

По генетическим признакам метаморфические горные породы подразделяются на регионально-метаморфические, контактовометаморфические и тектониты.

По петрографическим признакам (минеральному составу, строению, сложению) различают петрографические группы метаморфических пород: метаморфические сланцы, кристаллические сланцы, гнейсы, мигматиты.

Связь между петрографическими признаками и генетическими типами: при региональном метаморфизме образуются кристаллические сланцы, гнейсы и другие; при контактовом - скарны, роговики.

В соответствии с видами метаморфизма в генетической классификации горных пород выделяют группы метаморфических пород регионального, контактового и динамометаморфизма.

Различия пород определяются петрографическим составом материнской породы и степенью метаморфических изменений. Степень метаморфизма определяется глубинностью условий образования.

Таблица 3. Систематика метаморфических горных пород

\begin{tabular}{|c|c|c|c|}
\hline \multirow{2}{*}{$\begin{array}{l}\text { Группы } \\
\text { метаморфических } \\
\text { пород }\end{array}$} & \multirow{2}{*}{$\begin{array}{l}\text { Типичные } \\
\text { минералы }\end{array}$} & \multicolumn{2}{|l|}{ Исходные породы } \\
\hline & & Осадочные & Магматические \\
\hline Метапелиты & $\begin{array}{|lr|}\text { Кварц, полевые } & \text { шпаты, } \\
\text { слюды, } & \text { андалузит, } \\
\text { кордиерит, } & \text { дистен, } \\
\text { силлиманит, } & \text { гранат, } \\
\text { ставролит } & \end{array}$ & $\begin{array}{l}\text { Глинистые породы, } \\
\text { алевролиты, } \\
\text { аркозы }\end{array}$ & \begin{tabular}{|lr} 
Плутонические & и \\
вулканические & породы \\
кислого состава &
\end{tabular} \\
\hline Метабазиты & $\begin{array}{l}\text { Плагиоклазы, poговая } \\
\text { обманка, пироксен }\end{array}$ & Мергель, граувакки & \begin{tabular}{|lr} 
Плутонические & и \\
вулканические & породы \\
основного и & среднего \\
составов & \\
\end{tabular} \\
\hline
\end{tabular}


В верхней зоне метаморфизма распространены тонкозернистые с совершенной сланцеватостью породы: филлиты, серицитовые, серицитовохлоритовые, тальковые и тальково-хлоритовые сланцы, а также породы, не обладающие сланцеватостью - зелёно-каменные, тальковые и хлоритовые породы.

Физико-механические свойства метаморфических горных пород во многом очень близки к магматическим, что обусловлено наличием у них жестких, преимущественно кристаллизационных связей. Метаморфические породы практически водонепроницаемы и за исключением карбонатно-доломитовых разностей не растворяются в воде.

Для большинства метаморфических пород характерна анизотропность свойств, обусловленная их слоистостью, сланцеватостью. Сланцеватостью определяется и значительная выветриваемость этих пород, а также пониженная устойчивость на природных склонах и в бортах искусственных выработок. Многие метаморфические породы образуют тонкоплитчатые или листоватые весьма подвижные осыпи. Особенно ярко это проявляется у слабометаморфизованных пород, например, у глинистых сланцев.

К породам, которые подверглись воздействию глубокого регионального метаморфизма и имеют наибольшее распространение, относятся гнейсы, кварциты, кристаллические сланцы. Несколько реже встречаются мраморы и мраморизованные известняки, обычно они приурочены к областям древней докембрийской складчатости, где слагают массивы больших размеров.

При выветривании физико-механические свойства гнейсов изменяются особенно сильно. Наибольшей стойкостью обладают кварцевые гнейсы; полевошпатовые и биотитовые гнейсы выветриваются значительно интенсивнее. Наиболее прочными и устойчивыми метаморфическими породами к процессам выветривания являются кварциты. Обычно они слагают отдельные массивы мощностью до 100м и более или залегают в виде прослоев различной мощности в толще таких же высокометаморфизованных сланцев.

Самое большое разнообразие физико-механических свойств наблюдается у кристаллических сланцев. От массивных метаморфических пород их отличает слоистость, сланцеватость, кливаж. Эти особенности вызывают резкую анизотропность их свойств, позволяющую раскалываться на тонкие, часто листоватые плитки. Сланцеватость и кливаж сланцев, особенно хлоритсерицитовых и глинистых, способствуют соскальзыванию и оползанию.

Своеобразную группу метаморфических пород образуют так называемые «зеленые» сланцы - хлоритовые, хлорит-серицитовые, тальк-хлоритовые. Они сравнительно устойчивы к воздействию химического выветривания, нелегко 
разрушаются при периодическом промерзании и оттаивании. По прочности они уступают вышеописанным сланцам.

Наименее устойчивы к выветриванию глинистые сланцы. В воздушносухом состоянии они обладают значительной прочностью, но при водонасыщении довольно часто разваливаются. Эти породы хорошо противостоят химическому выветриванию, но при резком колебании температур (замерзание, оттаивание) легко разрушаются, образуя при этом на склонах подвижные, труднопроходимые осыпи. Насыщение этих осыпей водой после сильных ливней приводят к формированию в горных районах селевых потоков.

Карбонатные метаморфические породы могут образовываться как при региональном, так и при контактовом метаморфизме, главным здесь является наличие среди факторов метаморфизма значительных температур и давлений.

$$
\text { Наиболее характерной породой этой группы }
$$

является мрамор - перекристаллизованный известняк, структура и текстура которых диктуют физические и механические их свойства. Отличительной чертой мраморов среди метаморфических пород является их, хотя и слабая, но растворимость в воде, которая содержит углекислоту. Это определяет значительно меньшую закарстованность мраморных массивов, чем в толщах, сложенных известняками и доломитами. Мрамор довольно устойчив к выветриванию, сохраняет крутые, вплоть до «отвесных» природные склоны

Наиболее распространенной породой, образующейся при термальном контактовом метаморфизме, являются роговики. Для них характерна полная перекристаллизация исходного материала. Обычно это темные плотные породы, имеющие мелкозернистую структуру. Чаще других встречаются кварц-биотитполевошпатового состава породы, образовавшиеся по пелитовому материалу. Все роговики устойчивы к выветриванию. Необходимо заметить, что на сложенных ими природных склонах формируются обвалы, курумы, крупнощебенистые осыпи.

Тектониты - породы, которые обычно не относят к кластическим метаморфическим, являются в то же время типичными представителями катакластического метаморфизма и включают в себя брекчии трения, катаклазиты, милониты. Это раздробленные, иногда перетертые породы различной степени цементации.

Брекчии трения состоят из различной величины обломков пород, как правило, необработанных, сцементированных тонкораздробленной массой тех же пород.

Катаклазиты отличаются от брекчий трения меньшим размером обломков. Они характеризуют начальные стадии изменения пород. Катаклазиты сохраняют во многом черты исходного материала, поэтому соответственно и различают 
катаклазиты гранитов, катаклазиты габбро и др. В целом эти породы еще сохраняют достаточно высокую прочность на раздавливание.

Милониты характеризуются резко выраженной рассланцованностью, по существу это микробрекчии (составные части милонитов распознаются только под микроскопом) грубо- или тонкополосчатой текстуры. Все тектониты в условиях естественного залегания имеют достаточно высокую плотность. Катаклазированные породы интенсивно выветриваются, относительно легко размываются, поставляя материал, формирующий осыпи и способствующий развитию других склоновых процессов.

\subsection{4 Осадочные горные породы}

Осадочные горные породы - образуются путём накопления продуктов разрушения магматических, метаморфических и более древних осадочных пород и слагают самые верхние слои земной коры, покрывая своеобразным чехлом породы магматического и метаморфического происхождения. Они составляют всего 5\% земной коры, но земная поверхность на 75\% своей площади покрыта именно этими породами при мощности отложений от нескольких дециметров до нескольких сот метров. Лишь в прогибах земной коры, так называемых геосинклиналях, мощность осадочных горных пород достигает нескольких километров. Почвенный покров планеты формируется в основном на осадочных горных породах.

Порода, за счёт разрушения которой образуется осадочная порода, называется материнской. Образование осадочных пород начинается с выветривания материнской породы (гипергенез - разрушение кристаллических и других пород, образование новых минералов, обломков пород, обломков минералов, коллоидных и истинных растворов), прохождения стадии переноса (транспортировка) и завершается стадией осаждения (седиментация, седиментогенез -перенос и отложение материала, образование осадка) и последующей стадией превращения рыхлого осадка в осадочную горную породу (диагенезом).

Начальные изменения осадочной породы называются стадией катагенеза, глубокие изменения осадочной породы, приводящие к образованию метаморфизированных осадочных пород, называются метагенезом. Эти две стадии объединяются одним понятием - эпигенез. Все стадии составляют процесс литогенеза. 
Под литогенезом понимают совокупность геологических процессов, определяющих современный состав, строение, состояние и свойства осадочных горных пород.

Основным механизмом переноса продуктов выветривания является вода, а в условиях сухого климата - ветер. Осаждение происходит путём оседания продуктов выветривания из взвешенного состояния при снижении скорости транспортирующей среды (водных потоков, ледников) Таким образом, выпадают механические осадки, состоящие из обломков различных размеров. При насыщении транспортирующей среды растворёнными минеральными веществами происходит выпадение минеральных осадков.

Таблица 4. Состав осадочных горных пород

\begin{tabular}{|c|c|c|c|c|c|c|c|c|c|c|}
\hline \multirow[b]{2}{*}{$\begin{array}{c}\text { Генезис } \\
\text { пород }\end{array}$} & \multicolumn{10}{|c|}{ Состав пород } \\
\hline & 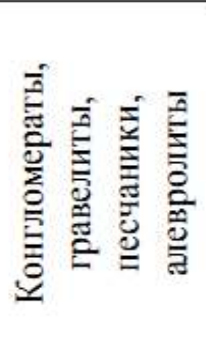 & 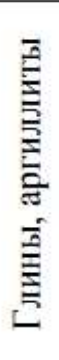 & 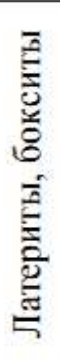 & 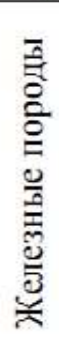 & 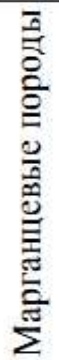 & 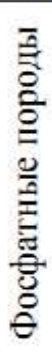 & 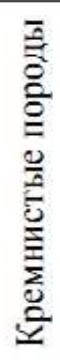 & 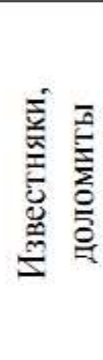 & 音 & 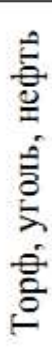 \\
\hline обломочный & + & + & + & + & & & & + & & \\
\hline хемогенный & & + & + & + & + & + & + & + & + & \\
\hline хемобиогенный & & & & + & + & + & + & + & & \\
\hline биогенный & & & & & & + & + & + & & + \\
\hline
\end{tabular}

При выпадении минеральных веществ из коллоидного раствора образуются коллоидные осадки (изменяется $\mathrm{pH}$ раствора или характер растворённых электролитов).

Широко распространено органогенное осаждение, когда живые организмы ассимилируют минеральные вещества из сильно разбавленных растворов для построения скелетных частей. После их гибели эти вещества накапливаются в виде органического ила, обломков скелетных частей. Выпавший осадок в дальнейшем претерпевает уплотнение (самоуплотнение) под действием веса вышележащих наслоений, а иногда цементацию и окаменение, и осадок превращается в осадочную горную породу (процесс диагенеза).

Отличительными особенностями осадочных горных пород, отражающими условия их образования, являются слоистость, пористость, наличие окаменевших остатков животных и растительных организмов. Состав и свойства осадочных горных пород зависят от климатических условий.

В состав осадочных пород входят следующие группы минералов: 
- минералы реликтовые, унаследованные от исходной материнской породы (первичные минералы, устойчивые к выветриванию

- кварц, полевые шпаты, слюда, роговая обманка, авгит, магнетит, гематит, апатит, циркон и др.); по ним судят о материнских породах, из которых образованы осадочные породы;

- минералы собственно осадочные, образовавшиеся путём химического или биохимического осаждения (вторичные минералы, образующиеся при экзогенных процессах:

- группа кремнезема - опал, халцедон, кварц;

- гидроксиды алюминия - гидраргиллит, диаспор, бемит;

- гидроксиды железа - гетит, лепидокрокит;

- оксиды марганца - вад, псиломелан, пиролюзит;

- вторичные силикаты - каолинит, монтмориллонит, бейделлит, галлуазит, серицит;

- карбонаты - кальцит, доломит;

- галогениды - галит; сульфаты - гипс, мирабилит). Эти минераль являются главныли породообразующими минералами осадочных пород.

В породах из обломочного материала минералы - новообразования представляют собой цемент, заполняющий промежутки между обломками (конкреции, желваки, стяжения). В осадочных породах обычно присутствуют остатки растений и животных.

\subsection{5 Классификация осадочных горных пород}

Осадочные породы классифицируются по происхождению и условиям образования.

По происхождению выделяют следующие генетические типы осадочных пород: механические осадки (обломочные горные породы), химические осадки, органогенные осадки, пирокластические осадки.

Осадочные породы обломочного происхождения представляют собой продукты механического разрушения горных пород, накапливающиеся и сохраняющиеся в рыхлом или сцементированном состоянии.

По величине обломков различают такие фракции зернового (гранулометрического) состава обломочных пород: грубообломочная - величина обломка и зёрен от 2 и более мм; среднеобломочная (песчаная) - от 0,05 до 2мм; мелкообломочная (пьлеватая) - от 0,001до 0,05мм; тонкообломочная (физическая глина) - менее 0,001мм. 


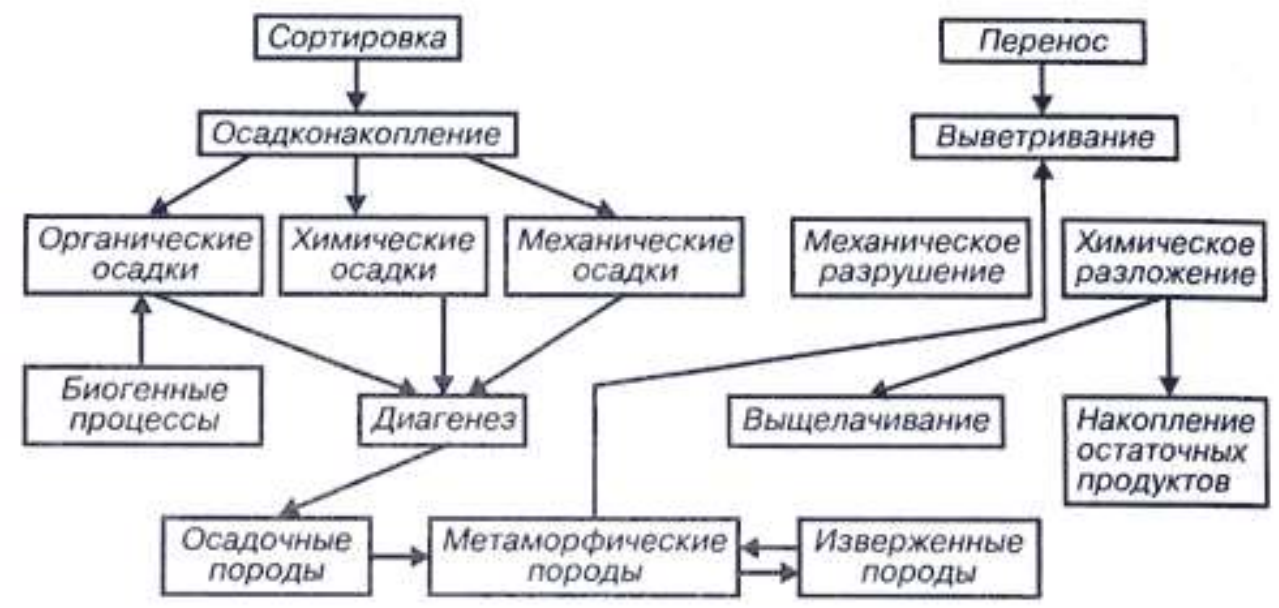

Рисунок 5. Осадочные горные породы

В зависимости от гранулометрического состава обломочные породы подразделяются (таблица 3):

- грубообломочные породы - обломки более 2мм в диаметре (гравий, щебень, галечник или сцементированные разности (брекчии, гравелиты, конгломераты);

- песчаные породы - зёрна диаметром 0,05...0,2мм (пески, песчаники );

- глинистые породы - частицы менее 0,05мм в диаметре, т. е. пылеватые и глинистые частицы (супеси, суглинки, глины);

- обломочные породы смешанного состава (гравелистые пески, валунники, супеси, суглинки, глины).

Таблица 5 - Классификация обломочных осадочных пород

\begin{tabular}{|c|c|c|c|c|c|c|}
\hline \multirow{2}{*}{\begin{tabular}{|l} 
Размер \\
обломков, \\
мм \\
углова- \\
тые \\
\end{tabular}} & \multirow{2}{*}{$\begin{array}{l}\text { Обломки } \\
\begin{array}{l}\text { окатан- } \\
\text { ные }\end{array} \\
\end{array}$} & \multirow{2}{*}{ 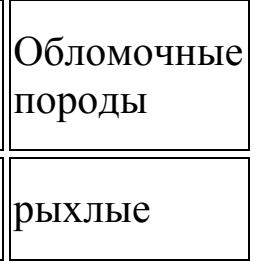 } & \multicolumn{4}{|c|}{ Фракции по ГОСТ 25100-95 } \\
\hline & & & $\begin{array}{l}\text { сцементированные } \\
\text { из частиц }\end{array}$ & & & \\
\hline $\begin{array}{l}\text { углова- } \\
\text { тых } \\
\end{array}$ & $\begin{array}{l}\text { окатан- } \\
\text { ных }\end{array}$ & & & & & \\
\hline Более 200 & Глыбы & Валуны & $\begin{array}{l}\text { Грубообло- } \\
\text { мочные }\end{array}$ & Брекчии & $\begin{array}{l}\text { Конгло- } \\
\text { мераты }\end{array}$ & $\begin{array}{l}\text { Валунная } \\
\text { (каменистая) }\end{array}$ \\
\hline $200-40$ & Щебень & Галечник & $\begin{array}{l}\text { Галечнико-вая } \\
\text { (щебенистая) }\end{array}$ & & & \\
\hline $40-2$ & Дресва & |Гравий & $\begin{array}{l}\text { Гравийная } \\
\text { (дресвяная) }\end{array}$ & & & \\
\hline $2-0,05$ & Песчаные & Песчаные & Песчаники & Песчаная & & \\
\hline $0,05-0,005$ & Пылеватые & Пылеватые & Алевролиты & Пылеватая & & \\
\hline $\begin{array}{l}\text { Менее } \\
0,005\end{array}$ & Глинистые & Глинистые & & \begin{tabular}{|l} 
Аргил- \\
литы
\end{tabular} & Глинистая & \\
\hline
\end{tabular}


Осадочные породы химического происхождения образуются при осаждении минерального вещества из истинных и коллоидных растворов. Осаждение происходит в лагунах, реже пресноводных озёрах или у мест выхода подземных вод на поверхность.

Органогенные осадочные породы слагаются из скелетных остатков организмов. Различают: зоогенные осадочные породы, слагающиеся из скелетных частей животных организмов (известняки, кремнистые породы), фитогенные, состоящие из остатков растительного происхождения (уголь, некоторые известняки и другие) и смешанные (зоофитогенные) из остатков животного и растительного происхождения. Поскольку процессы химического и органогенного осаждения минеральных веществ протекают одновременно, то образующиеся породы объединяют в одну группу.

Пирокластические породы образуются путём осаждения твёрдых продуктов вулканических извержений - вулканического пепла, лапиллей, бомб. Минеральное вещество пирокластических пород - магматического происхождения, а способ образования осадочный (вулканические туфы, туфобрекчии и другие).

\subsection{6 Обломочные породы}

Наиболее широкое распространение среди осадочных горных пород получили обломочные породы. Они состоят из обломков различных горных пород и минералов - рыхлых или сцементированных.

Обломочные породы состоят из механических обломков материнских пород различной величины: угловатые обломки (неокатанные) - глыбы (>200мм), щебень (200..40мм), дресва (40..2мм) и окатанные - валуны

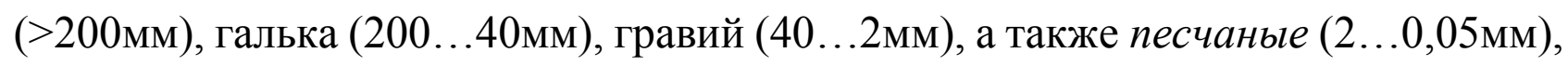
пылеватые (0,05 ..0,005 мм), глинистые ( $<0,005$ мм).

Минеральный состав обломков зависит от материнской породы; в нём преобладают механически прочные и химически стойкие минералы, способные противостоять процессам выветривания и разрушения.

В зависимости от величины обломков породы делятся на:

- грубообломочные (nсефиты; по-гречески «псефос» - камешек), обломки различного петрографического и минералогического состава размером от 2,0мм до нескольких метров в диаметре; среди грубообломочных пород выделяют несцементированные (валунные, кремнисто-щебёночные накопления, гравий $и$ 
галечник) и сцементированные (конгломераты - гравий+галечник, валунные отложения, брекчии - щебень +камень).

Неокатанные угловатые обломки (глыбы, камни, щебень, дресва) образуются при механическом разрушении горных пород. Камни, щебень и дресва являются обычно элювием различных скальных горных пород, но могут перемещаться под воздействием силы тяжести и накапливаться у подножия горных склонов.

Окатанные обломки горных пород (валуны, галька, гравий) встречаются среди аллювиальных отложений, широко распространены среди ледниковых и водно-ледниковых наносов. Скопления валунов, лишенных тонкозернистого материала, образуют так называемые валунные поля.

Щебень и дресва различного петрографического состава, сцементированные природными цементами (глинистым, карбонатным, кремнистым, железистым), получили название брекчия. Сцементированные галечник и гравий образуют так называемые конгломераты.

- среднеобломочные (песчаные, или псаммиты; «псаммос» по-гречески песок), диаметр обломков от 0,1 до 2мм; среднеобломочные породы - рыхлые несцементированные разности - пески и сцементированные - песчаники.

В зависимости от размера зерен пески разделяются на грубозернистые $(1,0 \ldots 2,0$ мм), крупнозернистые $(0,5 \ldots 1,6 м \mathrm{~m})$, среднезернистые $(0,25 \ldots 0,5 \mathrm{Mм})$ u мелкозернистые $(0,1 \ldots 0,25 \mathrm{~mm})$.

По минеральному составу выделяют пески полимиктовые - состоящие из кварца, полевых шпатов, слюды (аркозовые пески); олигомиктовые - 75\% зёрен одного минерала - кварца (кварцево-глауконитовые пески); мономинеральные более $95 \%$ из одного минерала.

Наиболее распространены кварцевые пески крупно,- средне,- или мелкозернистые. Содержат пылеватые и глинистые частицы, иногда органические вещества.

По происхождению пески могут быть речными, озерными, морскими, дюнными.

Сцементированные пески называются песчаниками. Как и пески, они могут иметь различный минералогический состав и различный размер зерен. Цементом служат глинистые, карбонатные, сульфатные, железистые, кремнистыл вещзества.В зависимости от состава цемента различают песчаники глинистые, известковистые, железистыл, кремнистые.

Наиболее прочны кремнистые песчаники, состоящие из кварцевых зерен. Глинистые песчаники легко размокают. Грубозернистые песчаники сложного состава, содержащие обломки основных, обычно эффузивных горных пород, 
называются граувакками. Цвет песков и песчаников зависит от цвета входящих в их состав минеральных зерен и цвета цементирующего вещества.

- тонкообломочные, или алевриты (по-гречески «алеврон» - мука), диаметр обломков от 0,1 до 0,01мм состоят из частиц промежуточной величины между песчаными и глинистыми. Наиболее распространён алеврит, состоящий из пылеватых частиц. Алевритовые породы, сцементированные преимущественно известковым или кремнистым цементом, называются алевролитами, плотные слоистые породы. Они не размокают в воде.

Мелкозернистые породы - это тонкозернистые пылевидные породы морского, речного, водно-ледникового и эолового происхождения. Представителями алевритовых пород являются лессовидные породы, лессы, покровные пылеватые суглинки и супеси.

Лёссы- однородная, существенно пылеватая светло-жёлтая рыхлого сложения порода. Лессы состоят примерно на 50\% из кварца, до 20\% в их составе приходится на глинные минералы (главным образом каолинит) и 20..25\% составляет кальцит. В качестве примесей в состав лесса входят оксиды и гидроксиды железа, придающие ему палевый, коричнево-палевый цвет, слюды, полевые шпаты и другие минералы. Для лессов характерна высокая пористость (50...60\% и более).

Суглинки и супеси (в большинстве случаев четвертичного возраста) в составе - пылеватые, песчаные и глинистые частищыл.

Смешанные песчано-глинистые породы - супеси и суглинки. Супеси содержат от 10 до 20\% глинистых частиц (диаметром меньше 0,01мм), а суглинки - от 20 до $50 \%$.

\subsection{7 Глинистые породы}

Глинистые породы (тонкодисперсные) породы, или пелиты (погречески «пэлес» - глина), составляют 50-60\% общего объёма осадочных пород. Глины - породы, состоящие на $30 \%$ из частиц размером менее 0,002мм, и от 0,002 до 0,05мм. Типичный представитель этих пород глина - землистая порода, во влажном состоянии пластична, при высыхании твердеет и приобретает твердость камня при обжиге. Глины состоят в основном из продуктов химического разрушения и в меньшей мере из механических обломков горных пород.

Породообразующие минералы - каолинит, монтмориллонит и другие они объединяются под названием глинистой субстанции, от которой зависят все важнейшие свойства глин. 
В состав глин, кроме породообразующих минералов, входят неглинистые минералы, образовавшиеся в процессе накопления минерального ила или же при последующих диагенетических его изменениях (оксиды и гидроксиды железа и алюминия, карбонаты, сульфаты, фосфаты, окислы марганца и органическое вещество и обломочные, реликтовые (кварц, полевые шпаты, слюды, хлориды и другие)

Большинство глин имеют полиминеральный состав. Однако встречаются разновидности с преобладанием одного минерала - каолинитовые (каолин) $u$ монтмориллонитовые (бентониты, флоридины) глиныл.

Каолинитовые глины имеют белый цвет и называются каолином. Это жирная глина. Примесь кварца, халцедона, опала, окислов железа делает глину тощей. Глины, состоящие из каолинита, гидроксидов алюминия и слюды, называются огнеупорными (температура плавления около $1700^{\circ} \mathrm{C}$ ).

Глины из монтмориллонита называются монтмориллонитовыми (разновидности их - бентонитовые глины, кил, гумбрин), они обладают высокой поглотительной способностью.

Глины довольно плотные породы, в водонасыщенном состоянии пластичны, при обжиге - камнеподобны. Жирные глины содержат большое количество глинистого материала, тощие - песчаного (легкоплавкие и тугоплавкие). При уплотнении и окаменении глины обезвоживаются, теряют пластичность, цементируются, чаще всего кремнезёмом, и превращаются в аргиллиты.

Глинистые породы образуются из продуктов выветривания магматических пород. Если продукты выветривания остаются на месте разрушения материнской породы образуются остаточные глины, однородные по минеральному составу, не имеют слоистости и сохраняют черты материнской породы. При переносе и отложении глинистые материалы смешиваются с крупнообломочными частицами и образуются осадочные глины (переотложенные). Они слоисты и разнообразны по минеральному и зерновому составу.

\subsection{8 Химико-органогенные породы}

Осадочные горные породы химического и органогенного происхождения тесно связаны между собой: химические осадки часто выпадают при прямом или косвенном участии организмов, а многие органогенные осадки связаны с химизмом среды. В эту группу химико-органогенных пород входят карбонатные, кремнистые, фосфатные, аллитовые, железистые породы, сернокислые и галоидные, латериты и бокситы (алюминиевые), и каустобиолиты, образовавшиеся путём химического или органогенного осаждения. 
Kарбонатные nороды - известняки, доломиты, мергеля, мел, отличаются содержанием минеральных компонентов - кальцита, доломита и глинистых минералов. Известняки содержат 90-95\% кальцита $\left(\mathrm{CaCO}_{3}\right)$, доломиты - 90-95\% $\mathrm{CaMg}\left(\mathrm{CO}_{3}\right)_{2}$, мергели - кальций+ 20-50\% глинистых минералов.

Известняки $\left(\mathrm{CaCO}_{3}\right)$ имеют органогенное и химическое происхождение и состоят из кальцита. Органогенные известняки состоят из известковистых скелетов и остатков раковин животных и растений. Они подразделяются на коралловые, водорослевые, известняки - ракушечники, мел (на 60-70\% состоит из морских одноклеточных водорослей), известковые туфыл (при осаждении из минеральных источников), оолитовые известняки, обломочные, кристаллически зернистые (известняки, образовавшиеся за счёт перекристаллизации других типов известняков).

В зависимости от преобладания остатков тех или иных организмов различают известняки криноидные (из скелетов морских лилий), фузулиновые (из корненожек-фузулин), нуммулитовые (раковины в виде монеты), мианковые, коралловые и др. Известняки, состоящие из целых раковин, называются ракушечниками, из битых - детритусовыли. $К$ органическим известнякам относится и мел, состоящий на 96..99\% из мелких частиц порошковатого кальцита, панцирей микроскопических морских водорослей и мельчайших раковин фораминифер.

Известняки химического происхождения представлены плотными микрозернистыми массами или встречаются в виде скопления мелких сцементированных шариков - оолитовые известняки, известковых туфов и натеков (сталактиты, сталагмиты, корки). Известковые туфы образуются при осаждении кальцита из холодных и горячих водных источников.

Мергели представляет собой известняково-глинистую породу с содержанием глинистых частиц 30-50\%. Это тонкозернистые и однородные породы. Цвет серый, белый, коричневато-желтый. Вскипает от соляной кислоты, при этом на поверхности остается грязно-серое пятно.

Во влажном состоянии пластичны (мергели-натуралы используются для производства портландцемента).

Доломиты $\left[\mathrm{CaMg}\left(\mathrm{CO}_{3}\right)_{2}\right]$ - образуются при метасоматическом замещении известняков под воздействием подземных магнезиальных растворов и других процессов. Доломит состоит из минерала доломита и содержит в качестве примесей кальцит, глинистые минералы, гипс, флюорит, целестин, опал и др. Доломиты в отличие от известняков реагируют с соляной кислотой только в порошке. Между доломитами и известняками имеются промежуточные разности: известковистый доломит содержит не менее $50 \%$, a доломитизированный известняк - не менее 5\% доломита. 
Кремнистые породы органогенного и химического происхождения состоят преимущественно из кремнезема. К ним относятся радиоляриты, диатомиты, трепел, опоки и яшмы

Радиоляриты представляют собой слабо сцементированные опаловые скелеты морских одноклеточных организмов радиолярий. Цвет породы желтосерый или красный. Встречаются в Поволжье, на Урале и на Кавказе.

Диатомиты состоят из рыхлых или сцементированных опаловых микроскопических скелетов диатомовых водорослей.

Порода белая или светло-желтая, легкая, пористая, мягкая и липнущая к языку (сильно поглощает воду). Встречается в Поволжье от Ульяновска до Камышина, в Куйбышевской области.

Трепел состоит из зернышек опала размером $0,01 \ldots 0,001$ мм с небольшой примесью скорлупок диатомовых водорослей и остатков кремнистых скелетов радиолярий и губок. Возможно это измененные диатомиты или биохимическая порода. Цвет породы белый, желтый, бурый, светло-серый, темно-серый. Встречается в виде пористых или рыхлых мучнистых масс. Порода легкая, сильно поглощает воду. Залегает обычно в отложениях нижнемелового возраста на Украине, в Белоруссии, в Калужской и Смоленской областях.

Опока - опаловидная пористая порода белого или серого цвета, обладающая часто раковистым изломом. Напоминает трепел, но обычно более твердая и при ударе раскалывается с характерным звенящим звуком. Возможно, что по происхождению опоки являются измененными трепелами и диатомитами или породами химического происхождения. Залегают в меловых отложениях Нижнего и Среднего Поволжья.

Ящмы - твердые, непрозрачные породы с раковистым изломом, полосчатая или пятнистая, окрашенная окислами марганца и железа в красный, желтый, коричневый и зеленый цвета. Радиоляриевые разновидности яшм содержат остатки радиолярий и представляют собой измененные радиоляриты, иногда в значительной степени метаморфизированные. Яшмы безрадиоляриевые могут иметь вулканогенное, химическое и биохимическое происхождение. Используются как красивый поделочный камень.

Сернокислые $u$ галоидные nороды представляют собой типичные химические осадки. Выпадение их из растворов происходит в замкнутых водных бассейнах, мелководных заливах и соляных лагунах вследствие интенсивного испарения. Из пород этой подгруппы следует отметить каменную соль, состоящую из минерала галита $(\mathrm{NaCl})$, гипс $\left(\mathrm{CaSO}_{4} \cdot 2 \mathrm{H}_{2} \mathrm{O}\right)$, ангидрит $\left(\mathrm{CaSO}_{4}\right)$, сильвин (KCl), карналлит $\left(\mathrm{KCl} \cdot \mathrm{MgCl}_{2} \cdot 6 \mathrm{H}_{2} \mathrm{O}\right)$.

Железистые породы образуются в результате выветривания основных и ультраосновных магматических и метаморфических горных пород с высоким 
содержанием железа. Железистые породы накапливаются на месте разрушения этих горных пород или переносятся в озера и моря, где осаждаются в результате деятельности бактерий или под воздействием химических процессов. Наиболее распространены различные лимониты, представляющие собой механическую смесь гидроксидов железа с глинистым и песчаным материалом.

Латериты и бокситы образуются при выветривании алюмосиликатных магматических пород в условиях субтропического и тропического климата при чередовании засушливых и дождливых сезонов. Латерuты (по-латински «латер» - кирпич) - элювиальные образования, состоящие из глинозема (минералы диаспор, гидраргиллит) и гидроксидов железа. Латериты имеют красный цвет, землистое или бобовое (оолитовое) сложение. Мощность латеритной (красноземной) коры выветривания достигает десятков метров.

Озокерит и асфальт связаны с месторождениями нефти. Озокерит - горный воск, является продуктом полимеризации и уплотнения нефти. Элементарный состав близок к составу парафина. Порода мягкая, пластичная, цвет изменяется от желтого до темно-бурого, Температура плавления от 50 до 80. Асфальт порода более твердая, вязкая, почти черного цвета. Состоит из смеси масел, смол и асфальтенов. Температура размягчения от $20 \ldots 30$ до $80 \ldots 100^{\circ} \mathrm{C}$. Средний элементарный состав: $80 \ldots 85 \%$ C, 9..10\% Н. Сапропелить образуются из остатков водорослей и животных организмов, накапливающихся на дне озёр.

Пирокластические горные породы образуются путём осаждения твёрдых продуктов вулканических извержений - вулканического пепла, песка, бомб, ляпиллей и выброшенных обломков пород.

Вулканические туфы и туфобрекчии содержат до 25\% частиц песка, пыли и глины (осадочный материал). При увеличении количества осадочного материала породы называются туффитами (туфогеные брекчии, туфогенные песчаники). Характерна для этих пород шершавая поверхность, обусловленная остроугольной формой слагающих их обломков.

\section{4 Сырье с промышленно ценным химическим составом. Гипс и ангидрит}

Термины гипс и ангидрит применяют как к минералам (водосодержащему сульфату $\mathrm{CaSO}_{4} * 2 \mathrm{H}_{2} 0$ и безводному $\mathrm{CaS}_{4}$ ), так и к горным породам, сложенным в существенной степени этими минералами, с примесью глинистых минералов, карбонатов, галита, обломочных зерен квариза и других минералов.

Тонкозернистый просвечивающий агрегат гипса называют алебастром, а тонковолокнистый агрегат с поперечно-волокнистыми прожилкамиселенитом. Породы, сложенные гипсом, а также песчано-глинистым, 
алевритистым и известково-глинистым материалом, называют гажей, глиногипсом, ганчем, гипситом, арзыком. Иногда в этих породах в качестве примесей присутствуют щзебенка и галька (до 20 \%). Массовая доля гипса в глино-гипсе обычно составляет 45-60 \%, редко до 90 \%. Известны специфические пески, состоящие из гранул гипса (шт. НьюМексико в США), и породы, состоящие из гипса и ангидрита.

Цвет гипса бельй, серый, голубовато-серый, розовый, желтылй; окраска бывает пятнистой и линзовидно-полосчатой.

Для селенита характерны шелковистый отлив, полупрозрачность, светлая окраска (розовато-желтая, белая, светло-бежевая, кремовая) .

Ангидрит бывает светло-голубой, голубовато-серый, бельй, розовый, серый, фиолетовыц̆, окраска нередко пятнистая.

Одно из важнейших свойств гипса - способность при нагревании дегидратироваться, и затем при разведении водой давать пластичное тесто, способное твердеть, превращзаяь в искусственный камень. Кристаллизационная вода из гипса выделяется при температуре всего $65-70{ }^{\circ} \mathrm{C}$, но слишком медленно. При температуре $100-180{ }^{\circ} \mathrm{C}$ процесс ускоряется, гипс переходит в полугидрат $\mathrm{CaSO}_{4} * 0,5 \mathrm{H}_{2} \mathrm{O}$, который имеет большое практическое значение. При 200-220 ${ }^{\circ} \mathrm{C}$ из гипса возникает искусственный ангидрит, который способен растворяться в воде и на воздухе благодаря поглощению влаги, переходить в полугидрат. Если температуру обжига повысить до $350-$ $400{ }^{\circ} \mathrm{C}$, то образуется нерастворимый в воде ангидрит («мертвообожженный гипс»). А при обжиге при температуре $800-1000{ }^{\circ} \mathrm{C}$ начинает появляться (до 3 \%) свободная жженая известь СаО.

Этот продукт, содержащий жженую известь, называют эстрихгипсом; он очень медленно соединяется с водой и становится вяжущим веществом. Обжиг при температуре $1600{ }^{\circ} \mathrm{C}$ переводит весь сульфат кальция в жженую известь. Гипс имеет невысокую твердость (2), ангидрит - несколько более высокую (3$3,5)$; мягкость пород позволяет легко их обрабатывать. В ряде случаев гипс и ангидрит обладают высокими декоративными качествами.

Строительный гипс, как и его мелкозернистую декоративную разность, называют алебастром, хотя по массовой доле воды они сильно различаются; этот гипс получают путем обжига природного гипса при температуре 130 - 180 ${ }^{\circ} \mathrm{C}$ в течение двух часов.

Гипс используют в различных областях. Из строительного гипса делают перегородные панели, плиты, сухую, гипсовую штукатурку, звукопоглощзающие плиты, декоративные строительныле изделия. Высокопрочный гипс получают автоклавной обработкой. Отливки из такого гипса имеют временное 
сопротивление на сжатие 15-40 МПа, в то время как отливки из гипса, обработанного без гидротермальной обработки,- 10-15 МПа.

Высокопрочный гипс применяют для получения гипсобетона, растворов для производства строительных деталей и в других целях. Гипсобетон обладает повышенной механической прочностью и быстрым схватыванием.

Формовочный гипс, в отличие от строительного, получают из более высококачественного гипсового камня. Нередко в качестве формовочного используют автоклавный гипс полуводный, а также смесь автоклавного и обыкновенного обжигового гипса. Формовочный гипс применяют в фарфорофаянсовом производстве для изготовления рабочих форм и моделей. Гипсовые вяжущие материалы широко используют в машиностроении для изготовления копий крупных деталей, на основе которых копировальные станки-автоматы производят изделия из металлов.

В медицине высококачественный гипс применяют в хирургии и стоматологии. Гипсовые добавки в цемент (3-5 \%) регулируют сроки твердения бетона. В металлургии гипс применяют в качестве флюса при плавке оксидных руд никеля. В сельском хозяйстве гипс идет на гипсование засоленных почв, в химической промышленности - для получения сульфата аммония (туковое сырье). Из гипса и ангидрита в некоторых странах получают серную кислоту и портландцемент. Эстрихгипс употребляют для производства плиточных и бесшовных полов, подоконников, лестничных ступеней, искусственного мрамора.

Гипсошлаковый цемент, получаемый путем тонкого измельчения гранулированного шлака, двуводного гипса и клинкера портландцемента, способен твердеть под водой. Ангидритовый цุемент получают обжигом гипса при 600-700 ${ }^{\circ} \mathrm{C}$ и последующим его помолом совместно с активизирующими схватывающими добавками. Иногда в этих целях используют и природный ангидрит. Гипс применяют в качестве облицовочного камня, а его разновидности - алебастр и селенит - для изготовления художественных изделий. Гажу, как и строительный гипс, применяют для получения штукатурных и вяжущих растворов, межэтажных перекрытий, карнизов и других строительных деталей. Гажу используют и в сельском хозяйстве (для борьбы с солончаками). Для производства вяжущих веществ в товарном гипсе сортов $1-4$ должны быть следующие минимальные массовые доли компонентов (6\%): гипс 95, 90, 80 и 70; кристаллизационная вода 19, 88, 18, 83, 16, 74 и 14, 64. Выделяют три сорта:

- гипс-ангидритового камня с соответствующими минимальными долями гипса и ангидрита в пересчете на $\mathrm{CaS} 04-2 \mathrm{H} 20$ (95, 90 и 80 \%) и серного ангидрита (44, $18,41,85$ и $37,20 \%$ ) 
- Гипсовый камень используется для производства гипсовых вяжущих веществ и цемента, а гипсангидритовый камень - только в цементном производстве.

При производстве гипсовых вяжущих веществ, а также белого, декоративного и гипсоглиноземистого расширяющегося цемента используют гипсовый камень только сорта 1. При производстве гипсовых вяжущих веществ используют фракции гипсового камня 60-300 мм, а при производстве цемента - гипсовый и гипсангидритовый камень фракций 0-60 м.

Выделяется ряд марок вяжущих гипсовых веществ: Г-2, Г-3, Г-4, Г-5, Г-6, Г7, Г-10, Г-13, Г-16, Г-19, Г-22, Г-25 (цифра в обозначении марок соответствует минимальному пределу прочности в МПа образцов-балочек с размерами 40Х40Х160 мм). Среди гипсовых вяжущих веществ выделяют три вида: быстротвердеющчие (A), нормальнотвердеющчие (B) и медленнотвердеющие (B). Начало срока схватывания (в мин - не ранее) A — 2; Б - 6; В - 20). Окончание схватывания (в мин - не позднее): А-15; Б - 30; В - не нормируется.

Выделяют также виды сырья по степени помола. Для степени помола с индексом I (грубый помол) максимальный остаток на сите с размером ячеек на свету 0,2 мм составляет 23 \%, с индексом II (средний помол) - 14 \%, а с индексом III (тонкий помол) - 2 \%. При этом для фарфоро-фаянсового и керамического производства этот остаток должен быть не более 1 \%. Кроме того, для фарфорофаянсового и керамического производства нормируется минимальное объемное расширение (до 1 \%), 0,15 \%), минимальная массовая доля примесей, нерастворимых в $\mathrm{HC} 1$ (до 1 \%), предельная массовая доля металлических примесей (не более 8 мг/кг), водопоглощение (не менее 30 \%)

Для изготовления гипсовых строительных изделий всех видов рекомендуются марки от Г-2 до Г-7 всех сроков твердения и степеней помола; для производства штукатурных работ, заделки швов и специильных цуелеймарки от Г-2 до Г-25 нормального и медленного твердения, среднего и тонкого помола; для медицинских цуелей — марки от Г-2 до Г-7 нормального и быстрого твердения, среднего и тонкого помола; для изготовления тонкостенных строительных изделий и декоративных деталей - марки от Г-2 до Г-7 тонкого и среднего помола, быстрого и нормального твердения; для изготовления форм и моделей в фарфоро-фаянсовой, керамической, машиностроительной и других отраслях промышленности, а также медицине - марки от Г-5 до Г-25 тонкого помола с нормальными сроками твердения.

Специиальный гипс применяется для изготовления акустических перфорированных плит и декоративных изделий. Он состоит в основном из полугидрата сульфата кальция и получается путем обжига тонкомолотого гипсового камня с добавлением (или без) поваренной соли. 
В гипсе, используемом в качестве флюса в металлургии, должны быть следующие массовые доли компонентов (в \%): $\mathrm{S}$ не менее 15; $\mathrm{CaO}$ не менее 28; $\mathrm{SiO}_{2}$ не более 6; $\mathrm{MgO}$ не более 6; $\mathrm{CuO}$ не более 0,03. Массовая доля $\mathrm{CaSO}_{4} \bullet 2 \mathrm{H}_{2} \mathrm{O}$ в медицинском гипсе должна быть не менее $95 \%$.

Минимально допустимое сжатие облицовочного гипса должно составлять 15 МПа. Минимальный объем блоков при получении облицовочных плит 0,2 м ${ }^{3}$ при наименьшем размере ребер —400 мм, наибольшем- 1500 мм.

\section{5 Сырье с промышленно ценными свойствами и составом. Глинистые породы}

Глины - осадочные породы, сложенные преимущественно пелитовыми частицами (диаметр менее 0,001 мм) и состоящие в основном из глинистых минералов. Каолины также состоят из тонкодисперсных частиц глинистых минералов, но формируются не осадочным путем, а при выветривании ряда горных пород или при их гидротермальном изменении. Однако, по традиции, к глинам относят также породы, образовавшиеся гидротермальным путем, если они имеют монтмориллонитовый состав.

К глинистым породам кроме собственно глин относят аргиллиты («уплотненные» глины), сланцеватые аргиллиты и даже глинистые сланцьь.

В начале ХХ в. П. А. Земятинский определял глину как горную породу, способную с водой образовывать пластичное тесто, сохраняющее по высыхании приданную ему форму, а после обжига приобретающее твердость камня. В настоящее время это определение пригодно только для пластичных глин, так как известны неразмокающие сухарные глины, камневки (флинтклей).

К группе глинистых пород относят также лёсс $u$ суглинки, а промежуточными между глинами и карбонатными породами являются мергеля, в которых массовая доля карбонатов составляет $50-75 \%$.

В состав глинистых пород входят глинистые и близкие к ним по физическим свойствам минералы («глинистая субстанция» глин), а также карбонаты, минераль бокситов, квари, полевые ипаты, амфиболь, слюды, пироксень, углистые вещцества, гидроксиды железа и марганца, рассеянные вылеления $u$ стяжения сульфидов, минераль кремнезема (халцедон, опал, кремни); среди акцессорных установлены магнетит, турмалин, рутил, цуиркон и другие минераль. К глинистой субстанции относятся следующие минералы:

- группа каолинита (каолинит, диккит, накрит), галлуазит;

-ряд минералов группьг слюд (гидрослюды) - вермикулит, иллит (гидромусковит), глауконит, гидробиотит; 
- группа смектитов - монтмориллонит, нонтронит, сапонит, бейделлит;

—группа пальгорскита - пальгорскит, сепиолит;

—группа хлоритов;

- ряд смешаннослойных образований.

Близкие к каолиниту высокодисперсные минералы с не вполне определенным составом относятся к аллофанам, гекторит по составу близок к сапониту, содержит литий. По составу глинистой субстанции среди глин выделяют полиминеральные и близкие к мономинеральным (анхимономинеральные) образования.

Глины обладают рядом свойств, которые обусловливают их промышленное применение - пластичностью, воздушной и огневой усадкой, адсорбиионными свойствами, связующей способностью, гигроскопичностью, гидрофильностью u $\partial p$.

Пластичность - способность после смачивания водой деформироваться без разрыва сплошности и сохранять форму, полученную в результате деформации. Степень пластичности определяется специальными методами.

Воздушная усадка - изменение объема смоченной глины на воздухе, а затем в сушильном шкафу при $\Pi{ }^{\circ} \mathrm{C}$.

Огневая усадка - изменение объема глины в процессе обжига. Огневая усадка огнеупорных глин при $1200{ }^{\circ} \mathrm{C}$ составляет, например, 7,5-20,5\%, а при $1300{ }^{\circ} \mathrm{C}$ достигает $23 \%$. Для уменьшения усадки в глины добавляют «отощиающие» примеси (кварцевый песок и др.).

Адсорбционные свойства определяются способностью к адсорбции глинами различных веществ (органических веществ, металлов и др.) и измеряются показателем адсорбции - поглощение сорбируемого вещества в мг на 1 г глин. К высокосорбирующим относятся монтмориллонитовые (бентонитовые), палыгорскитовые и сепиолитовые глины. Связующая способность выражается в способности пластичных глин связывать отощающие минералы, образуя при этом «тесто», пригодное для изготовления тех или иных форм, достаточно прочных после просушки. Связующая способность определяется сопротивлением сжатию, растяжению или излому образцов, отощенных стандартным песком в определенных массовых долях и затем высушенных.

Гигроскопичность - способность поглощать воду, связанная с явлениями адсорбции или абсорбции. Гигроскопичность особенно высока у глин монтмориллонитового состава, образцы которых, абсорбируя воду всей массой (а не только поверхностью), набухают. Гидрофильность - легкость смачивания 
водой, определяемая соотношением теплоты смачивания водой и неполярным бензолом.

Bспучивание - способность при обжиге увеличиваться в объеме. Это свойство необходимо для глин, из которых делают легкие заполнители, но является отрицательным фактором при производстве обычных керамических изделий. Повышенная способность к вспучиванию отмечается у глин, обогащенных органическим веществом. В связи с этим в некоторые глины специально добавляют некоторые вещества (например, мазут). Огнеупорность определяется температурой плавления.

По температуре плавления глины разделяются на:

- огнеупорные $\left(>1580^{\circ} \mathrm{C}\right)$,

- тугоплавкие $\left(1350-1580^{\circ} \mathrm{C}\right)$,

一легкоплавкие $\left(<1350^{\circ} \mathrm{C}\right)$.

Среди огнеупорных глин выделяют:

- высокоогнеупорные $\left(>1700^{\circ} \mathrm{C}\right)$,

- среднеогнеупорные $\left(1650-1700^{\circ} \mathrm{C}\right)$,

- низкоогнеупорные (1580-1650 $\left.{ }^{\circ} \mathrm{C}\right)$. Как правило, огнеупорность глин возрастает с повышением массовой доли $\mathrm{Al}_{2} \mathrm{O}_{3}$ и понижается с увеличением массовой доли щелочных и щелочноземельных металлов. Повышенная массовая доля органических веществ обычно не влияет на огнеупорность, но способствует получению черепка (продукта обжига) с увеличенной пористостью. Огнеупорность определяется с помощью стандартного набора образцов пирамидальной формы (пироскопов) - «конусов» Зегера. Номера «конусов» Зегера соответствуют определенным температурам плавления и определенным соотношениям $\mathrm{Al}_{2} \mathrm{O}_{3} / \mathrm{SiO}_{2}$ (для низких номеров и $\mathrm{CaO} / \mathrm{K}_{2} \mathrm{O}$ ).

Частичное плавление глин при обжиге называется спеканием. Для керамической промышленности большое значение имеет интервал температур, при которых глина находится на стадии частичного расплавления,- интервал спекания (от 100-M40 до 350- 400 C). Для некоторых глинистых пород, особенно продуктов обогащения каолинов, большое значение имеет показатель белизны (коэффициент отражения, определяемый на лейкометре). Показатель белизны высококачественного каолина составляет не менее 75\%. Определенное значение для оценки качества глин имеет цвет черепка, в частности, для некоторых изделий требуются «беложгущиеся» глины, т. е. глины, дающие белый черепок. В некоторых случаях дополнительно определяют термическую устойчивость, деформацию под нагрузкой при высоких температурах, массовую долю водь затворения, характер окраски, набухание и другие свойства глин. В промышленности также используется способность монтмориллонитовых глин, спекаясь при 900-1000 ${ }^{\circ} \mathrm{C}$, терять ионообменные 
свойства и прочно связывать при этом ранее сорбированные вещества (например, радиоактивные).

По особенностям свойств и состава среди глинистых пород выделяют следующие виды сырья:

- глинистыле иль;;

- каолинь;

- огнеупорные и тугоплавкие глины;

- высокосорбирующуие глины, легкоплавкие глины и аргиллиты;

- лёсс, суглинки;

- глинистые сланцьы.

Глинистые илы - сравнительно новый вид сырья, значение которого постепенно возрастает. По областям применения они тесно связаны с группой легкоплавких глин. Илы сложены тонкодисперсными частицами глинистых минералов и отличаются от глин в основном консистенцией (рыхлостью сложения) и повышенной массовой долей воды.

Каолины сложены минералами группы каолина, в существенно меньшей доле - кварцем, реликтами слюд, иногда полевых шпатов. Разности каолинов, заметно обогащенные калиевыми полевыми шпатами, называются щелочными каолинами. За стандартный образец каолина (КК) СЭВа принят образец месторождения Карловы Вары (ЧССР). Этот каолин состоит на 85-90\% из каолинита, в меньшей мере присутствуют слюды ряда «мусковит-иллит», хлорит, кварц, монтмориллонит, турмалин, биотит, пирит, сидерит, рутил и апатит. Средний состав стандартного каолина (в \%): Si02 47,06; Ti02 0,166; A1203 36,77; Fe03o6i4 0,982; MnO 0,015; MgO 0,192; CaO 0,236; Na20 0,032; K2O 1,063; Р205 0,090; C02 0,174; S 0,019; Н20+ 12,75. Каолин образовался за счет рудногорского гранита.

Огнеупорные и тугоплавкие глины сложены в основном каолинитом, галлуазитом, маложелезистыми гидрослюдами и монтмориллонитом с примесью кварца и других минералов. В составе глин отмечаются карбонаты, иногда стяжения пирита и марказита, желваки кремния; нередко присутствуют углистые вещества и гидроксиды железа. В некоторых разностях огнеупорных глин, особенно в сухарных глинах, установлены минералы бокситов.

К огнеупорным глинистым породам относятся пластичные, сухарные и полусухарные глины и некоторые глинистые сланцы. По массовой доле А1203 выделяют высокоосновные (более 40\%), основные (30-40\%), полукислые (15$30 \%$ и кислые (до $15 \%$ р) разности. В тугоплавких глинах по сравнению с огнеупорными повышена массовая доля гидрослюд и монтмориллонита.

Высокосорбирующие глины разделяются по минеральному составу на три группы: 
—бентонитовые;

- палыгорскитовые;

- сепиолитовые.

В группе бентонитовых глин ведущим минералом глинистой субстанции является монтмориллонит, но нередко широко развиты и смешаннослойные образования, а иногда - бейделлит, сапонит, гекторит. Выделяются две подгруппы- щелочные (в основном натровые) и щелочноземельные (в основном кальциевые) бентониты. Для первых характерна высокая сорбционная способность; щелочноземельные бентониты при использовании в качестве сорбентов требуют активации, осуществляемой путем обработки кислотами, щелочами или термическим воздействием.

В составе бентонитовых глин в качестве примесей имеются гидрослюды, цеолиты, квари, сапонит, бейделлит, кристобалит, обломки вулканического стекла, хлорит и другие минераль.

В пальгорскитовых глинах нередко присутствуют монтмориллонит, сепиолит, гидрослюды, смешаннослойные образования, карбонаты, цеолиты.

Сепиолитовые глины распространены весьма ограниченно. Легкоплавкие глины и аргиллиты сложены в основном железосодержащими минералами вермикулитом, хлоритами, нонтронитом, а также монтмориллонитом, бейделлитом, сапонитом; иногда в их составе присутствуют глауконит $u$ каолинит. Нередко легкоплавкие глины богаты органическими веществами, в них встречаются гидроксиды железа и марганца, стяжения пирита и марказита.

В лёссе установлены глинистые минералы, примеси алевролитовой фракции (кварц, полевые шпаты и другие минералы); карбонатный материал рассеян в массе породы или формирует стяжения. Суглинки в существенной мере сложены алевролитовой и псаммитовой фракцией.

Глинистые сланщь состоят из гидрослюд, хлоритов, каолинита, а также квариа и полевых шпатов; иногда в качестве примесей присутствуют монтмориллонит, углистыле вещества, карбонаты, сульфиды железа. Одним словом, большинство пород, которые относятся к низкотемпературным или среднетемпературным материалам.

Глинистые сланцы разделены на несколько групп по минеральному составу. Ведь в них есть и иные вещества. Именно они и стали поводом для разделения сланцев на несколько видов:

-Квасиовый сланец. К данному виду породы относятся те, в чей состав входит углистое вещество и серный колчедан.

-Кровельньий сланец.

-Сланеи аспидный. 
-Точильный сланец. К такому виду относятся те глинистые сланцы, в состав которых входит кремнезем.

И последний вид - грифельный сланец. Его можно без особого труда расколоть на небольшие столбики.

Каолины широко используют после обогащения (сухого или мокрого), реже применяют в необогащенном виде (каолин-сырец). Наряду с обогащением для получения каолинитового или кварцполевошпатового (из щелочных каолинов) концентрата прибегают и к облагораживанию. Облагораживанию обычно подвергают каолинитовый концентрат для придания ему более высокой белизны. К числу важнейших свойств каолина относятся его высокая белизна в сыром и обожженном состоянии, огнеупорность, сорбция, гидрофильность, пластичность, связующая способность, удовлетворительные интервал спекания и усадка, дисперсность.

Главные потребители каолинитового концентрата- бумажная $u$ керамическая отрасли промышленности, а также резиновая, мыловаренная, огнеупорная, химическая. В меньшей мере каолин используется при изготовлении пластмасс, карандашей, минеральных красок, силумина, ультрамарина, огнеупоров. Каолин-сырец применяют в цементной промышленности и в производстве полукислых огнеупоров. Попутно получаемые кварцевый и кварц-полевошпатовый концентраты используют в производстве керамических абразивных толе-рубероидных и других изделий.

Огнеупорные и тугоплавкие глины применяют в производстве шамота, в том числе огнеупорного шамотного кирпича, сталеразливочного припаса, папселей (коробов для обжига

Тугоплавкие глины широко применяются в строительной керамике для производства облицовочной плитки, облицовочных блоков, дренажных труб, кислотостойких и других изделий.

\section{6 Сырье для производства пористых заполнителей}

Природным сырьем для производства пористых заполнителей для легких бетонов служит большая группа горных пород, часть из которых имеет естественную высокую пористость (природные пористые заполнители), а другая часть приобретает ее при вспучивании после соответствующей термической обработки.

К первой группе относятся горные породы вулканического (пемзы, шлаки, туфы, крупнопористые базальты, андезито-базальты, андезиты) или осадочного происхождения (пористые известняки, известняки-ракушечники, спонголиты, опоки и другие кремнеземистые породы), из которых дроблением и 
фракционированием получают щебень с объемной насыпной массой не более

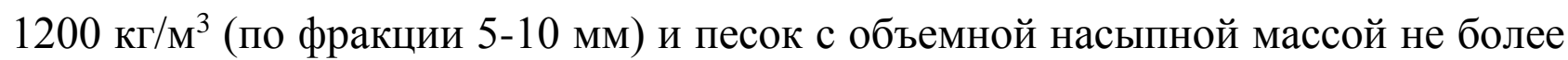
1400 кг/м ${ }^{3}$, отвечающие требованиям ГОСТа 22263-76 (2003) "Щебень и песок из пористых горных пород". В перспективе возможно использование еще целого ряда различных горных пород: туфодиатомитов (Приморский край), витрофиров (Средняя Азия), менилитовых сланцев (Карпаты), горелых пород (Кузбасс, Якутия), диктионемовых сланцев (Северо-запад), филлитов (Карелия) и др. Всего в лабораторных условиях оценены к настоящему времени 30 литологических разностей осадочных, изверженных и метаморфических пород и минералов, которые могут быть использованы для производства пористых заполнителей.

Ко второй группе пород, вспучивающихся при обжиге, относятся некоторые глинистые породы, кислые вулканические стекла и эффузивы, природные гидратированные слюды, шунгитсодержащие сланцы.

Требования к качеству пористых заполнителей, получаемых вспучиванием различных пород, лимитируются соответствующими государственными стандартами или техническими условиями.

Для получения керамзита пригодны легкоплавкие глины и глинистые сланцы, в составе которых преобладают монтмориллонит, бейделлит и гидрослюды. Оптимальное содержание органического вещества в керамзитовых глинах 0,5-1,5 \%. Наиболее благоприятный химический состав: $\mathrm{Fe}_{2} \mathrm{O}_{3}+\mathrm{FeO}$ не менее $4 \%, \mathrm{CaO}$ не более $6 \%, \mathrm{~A}_{2} \mathrm{O}_{3}$ до $20 \%$. Крупные включения не допускаются.

Аглопорит получают из песчано-глинистых пород, пелитовые части которых сложены минералами группы монтмориллонита, и гидрослюд. Присутствие сернистых и сернокислых соединений нежелательно. Содержание $\mathrm{CaO}$ допускается не более $10 \%$.

Для производства вспученного перлита наиболее пригодны кислые молодые вулканические стекла (перлит, обсидиан) и эффузивы (липариты и др.), содержащие не более $15 \%$ кристаллических включений. Оптимальный химический состав (в \%): $\mathrm{SiO}_{2} 65-67, \mathrm{Al}_{2} \mathrm{O}_{3} 12-14, \mathrm{Fe}_{2} \mathrm{O}_{3}$ 1,5-2,5, СaO 1,5-2,5.

\section{7 Вулканогенно-обломочные породы}

Вулканогенно-обломочные породы - это продукты деятельности вулканов и их взаимодействия с вмещающими породами и окружающей средой.Основными компонентами пород являются пирокласты (руг -огонь; 
klasto - ломать). Они образуются в результате эксплозий (exploz - взрыв) в вулканическом аппарате.

Пирокласты принято делить на витрокласты (А), кристаллокласты (Б) $u$ литокласть (B).

Витрокласты - продукты эксплозии охлажденных, но перекристаллизованных лав, насыщенных газовыми и парообразными компонентами. Лава может быть в разном состоянии : жидком, полужидком, вязком, твердом. В связи с этим взрывающиеся в ней пузырьки с газом и водой обусловливают появление разных форм витрокластов. Наиболее часто встречаются рагульчатые и серповидные формы -1, реже фьяммеподобные (fiamme- пламя) -2 и пемзовые (пемзокласты)-3. Все они изотропны.

Витрокласты лав различного состава различаются по показателю преломления и по характеру очертания обломков. Витрокласты кислого состава имеют показатель преломления меньше канадского бальзама $(\mathrm{n} \sim 1,50-1,52)$ и рагульчато-серповидную и пелуокластическую форму. Витрокласты кисло-, среднего, субщелочного и щелочного состава имеют показатель преломления близкий к канадскому бальзаму $(\mathrm{n}=1,52-1,54)$ и фьяммеобразную форму.

Витрокласты среднего и основного состава имеют показатель преломления 1,54 . Обломки имеют каплеообразную форму и часто содержат примесь рудных непрозрачных компонентов.

Кристаллокласты - это продукты эксплозии полукристаллических и раскристаллизованных лав. Кристаллокластами чаще всего становятся фенокристаллы кварца, санидина, реже биотитов, роговой обманки, пироксенов. Именно они первыми формируются в магме, часто в виде порфировых выделений, и подвергаются деформациям при взрывах в магматической камере. Кристаллы выглядят расколотыми обычно по спайности, имеют трещинки и следы выкалывания из эффузивов.

Литокласты - это продукты эксплозий застывших полукристаллических и кристаллических пород, сохранивших в обломках свойственную им микроструктуру. По особенностям структуры можно узнавать состав магм в вулканическом аппарате. Наиболее часто в литокластах наблюдаются гиалопилитовые, пилотакситовые, интерсертальные структуры, соответствующие андезибазальтовым магмам. Реже отмечаются в литокластах структуры, соответствующие кислым и щелочным магмам (аллотроморфнозернистая и трахитовая структуры).

Пирокласты могут смешиваться с магмой, а могут удаляться от вулканического аппарата на значительные расстояния. Попадая в осадок, обычно быстро литифицируются, превращаясь в твердую, напоминающую вулканическую магматическую породу. 
Пирокласты, падаюшие в виде охлажденного пепла и сохраняющие какоето время рыхлое состояние, принято называть тефрами. Это охлажденный твердый пористый пирокластический мелкопсефитовый материал.

Пирокластический материал и, прежде всего тефра, попадая в пути водного переноса, может перезахороняться. В этом случае он называется тефроидным.

В процессе транспортировки пирокластический материала смешивается с терригенным. Последний отличается большей пестротой состава, окатанностью, присутствием органогенных компонентов и растительного, и животного происхождения.

Смешанный материал принято называть вулканомиктовым (лат. мixtus смешанный).

Породы с пирокластическим материалом принято классифицировать с учетом его количества, особенностей смешения с магмой или терригенным материалом, характера и степени литификации и размерности обломков.

Классификация вулканогенно-обломочных пород была принята в 1981 году и утверждена петрографическим кодексом. Ведущий вклад в ее разработку внесли геологи института вулканологии Дальневосточного отделения РАН в г. Петропавловске-Камчатском.

В соответствии с классификацией принято выделять вулканокластические $u$ вулканогенно-осадочные nopodbl, различающиеся количеством в них пирокластического материала.

Вулканокластические

породы: лавобрекчии, автомагматические брекчии, кластолавы, туфолавы. Это породы образующиеся при излиянии магмы, ее частичном затвердевании и последующем раскалывании, а также при перемещении и захвате окружающего обломочного материала.

Общими особенностями таких пород являются: близкий состав микроструктуры и обломков и цементирующих лав; обычно крупный размер обломков; близость расположения к вулканическим аппаратам.

Лавокластиты, гиалокластиты. Общей и характерной особенностью этих пород является наличие в застывшей лаве крупных обломков ее ранее затвердевших образований пирокластического материала. Последний может быть различного состава и иметь размер обломков широкого диапазона. Лавовый цементирующий материал чаще имеет андезибазальтовый состав, как наиболее пластичный, растекающийся на значительные территории от вулкана и захватывающий окружающий обломочный материал.

Агглютинаты - породы вулканических аппаратов, представляющие собой спекшиеся брызги кипящих лав. Это обычно вишнево-красные комковатые очень крепкие породы. Их обломочный материал имеет сложную обрывочную конфигурацию и различные размеры. Состав и микроструктурные особенности 
близки. Обычно это гиалокласты средне-кислого состава. Характерна интенсивная гематитизация обломков и обрывков магм по периферии. Она возникает при окислении минералов, содержащих железо. Экзотермические реакции их окисления до гематита способствуют крепчайшему спеканию обломков.

Игнимбриты и спекииеся туфы - это продукты "палящих" туч. Породы сложены спекшимися, сплюснутыми каплями и вытянутыми пирокластами, выпадающими из туч в процессе их перемещения. Взрывающиеся вулканические аппараты обычно содержат обводненные, насыщенные газами, часто ликвированные кислые магмы. В связи с этим состав выпадающего пирокластического материала имеет существенно кислый и субщелочной состав.

Среди пирокластов много фьяммеобразных стекловатых капель и полос. Такие особенности характерны для игнимбритов, в то время как для спекшихся туфов более типичны мелкообломочные пестрые по составу пирокласты с микрогранулярной почти изотропной цементирующей массой. Размерность обломочного материала преимущественно псаммитопсефитовая, зависящая от дальности транспортировки. Текстуры пород ориентированные, полосчатые, нередко флюидальные.

Tефры - это рыхлые серые породы различных оттенков. Они состоят из обломков пузырчатых лав, обычно сферичной формы, разных, преимущственно мелкопсефитовых размеров. Среди сферичных обломков отмечаются крупные и мелкие лапилли, а также вулканический песок. Структуры обломков стекловатые и микрокристаллические. Состав дацитовый, андезитовый, риолитовый. Тефры накапливаются вблизи действующих вулканов и широко распространены на современной поверхности вдоль гряды Камчатских вулканов.

$T y \not b l$ - наиболее распространенные вулканогенно-обломочные породы. Это литифицированные породы, прошедшие стадии диагенетических и последующих эпигенетических преобразований. В породах содержится 90 \% пирокластов. Породы плотные, нередко с пониженным удельным весом. Цвет пород, текстурно-структурные особенности, агрегатное состояние обломков и их состав довольно разнообразны. Перечисленные признаки пород используются при детальном их изучении и классификации. Среди туфов по размерности обломочного материала выделяют: агломератовые, крупнопсефитовые, мелкопсефитовые, псаммитовые, алевритовые и пелитовые . По агрегатному состоянию обломков выделяют витрокластические, кристаллокластические, литокластические и смешанные разновидности.

Нередко по особенностям состава и микротекстур пирокластов можно установить и состав исходных магм - риолитовые, дациитовые, андезитовые, базальтовые и субщелочные. 
Туфы активно вовлекаются в процессы диагенетических и последующих преобразований. На стадии диагенеза обломочный материала, как крайне нестабильный в новой физико-химической и термодинамической обстановке, начинает быстро изменяться.

Стекловатые пирокласты девитрифицируются (раскристаллизовывают ся), по ним активно развиваются серицит, глинистые минералы, цеолиты, оксиды железа, лимонит. При гидратации стекловатых, обычно кислого состава туфов, образуются в изобилии опал и халцедон, которые превращают их в кремнеподобные породы.

Литокластические туфы - это порода более основного состава. Они претерпевают карбонатизацию, хлоритизацию, лимонитизацию. Нередко в них появляются цеолиты, в частности, анальцим.Вторичные преобразования туфов приводят в одних случаях к улучшению пустотного пространства, в других $-\kappa$ его уплотнению и полному запечатыванию. Улучшению коллекторских свойств туфов способствуют процессы выщелачивания пород на стадии наложенного эпигенеза. Это происходит в случае развития процессов углекислотного метасоматоза, сопровождающих вулканические процессы на заключительных, обычно сольфатарных этапах их развития.Углекислотный метасоматоз приводит и к интенсивной аргиллизации всех вулканогенно-обломочных пород.

Продукты аргиллизации - глинистые породы с мелким пирокластическим материалом. Обычно они образуются при так называемом "грязевом" вулканизме, завершающем вулканический процесс.Образовавшиеся породы носят название пелитовых туфов или аргиллизитов. Обычно они перекрывают комплекс вулканогенно-обломочных пород.

Туффиты - вулканогенно-обломочные породы, имеющие пирокластический материал в количестве 50-90\%. Остальной материал пород представлен обломками и пелитовым материалом экзогенного происхождения. Такие породы образуются на значительном расстоянии от вулканов или являются продуктами перемыва и переотложения ранее образовавшихся туфов. Наиболее характерной особенностью туффитов является сочетание пирокластических и органогенных компонентов. Не менее характерна пестрота состава и структурных особенностей обломочного материала.

Детальное изучение и классификация туффитов осуществляется по тем же признакам, что и туфов.

Туффиты, также как и туфы, активно подвергаются вторичным преобразованиям. Однако, наличие обломков, устойчивых к выветриванию пород и минералов, делает их менее уязвимыми для преобразований и позволяет их легко выделять, особенно на фоне интенсивно измененных туфов. 


\section{Вулканогенно-осадочные}

породы-

продукты

смешения

пирокластического и экзогеннообломочного материала с преобладанием последнего. Пирокластического материала в породах 50 \%. И в целом породы являются переходными к нормальным или экзогенно-обломочным породам.

Детализация пород, более дробная их классификация проводится по тем же признакам, что и туфовых и туффитовых пород. Преобразования вулканомиктовых пород также несут черты минеральных парагенезисов - в них появляются цеолиты, кремнисто-глинистые и карбонатно-хлоритовые новообразованные минералы. 


\section{2 ТЕХНОГЕННОЕ СЫРЬЕ}

\section{1 Техногенные минеральные ресурсы}

Источниками техногенных минеральных ресурсов являются техногенные минеральные образования и отходы горно-обогатительного, металлургического и других производств. Ресурсы подразделяются на следующие группы:

1. Техногенные минеральные образования (ТМО). К этой группе относятся отходы добычи, а также переработки полезных ископаемых. ТМО - это скопления минеральных веществ на поверхности земли или в горных выработках, образовавшиеся в результате отделения их от массива и складирования в виде отходов горно-обогатительного и металлургического производства.

2. Твердые промышленные отходы (ТПО). ТПО образованы из остатков сырья, материалов и полуфабрикатов, а также продуктов физико-химической переработки сырья различными отраслями промышленности. По некоторым оценкам ежегодно в мире создается около 20 млрд. т промышленных отходов.

3. Tвердые бытовые отходы (ТБО). К ним относятся бывшие в употреблении изделия и материалы, потерявшие свои потребительские качества в результате физического и морального износа Главными компонентами ТБО являются бумага, картон и пищевые отходы. Накопление твердых бытовых отходов в планетарном масштабе в настоящее время составляет около 4,5 - 5,0 млрд. т в год. ТБО складируются на полигонах бытовых отходов муниципального подчинения, либо накапливаются на несанкционированных свалках.

4. Отходы, улавливаемые при очистке отходящих газов и сточных вод. Эти отходы составляют сравнительно небольшую часть и, как правило, возвращаются в производство. Концентрация осадков в сточных водах составляет 20 - 100 г/л, а их объем по сравнению с объемом очищаемых стоков колеблется от 2 до $20 \%$. Например, в осадках очистных сооружений гальванических производств было определено (\%): Си-1,0: Zn-0,9; $\mathrm{Sn}-0,6 ; \mathrm{Ni}-0,3$ и др. Ежегодно образуется около 1000 т таких осадков.

5.Paдиоактивные отходы (PAO). В эту группу входят жидкие и твердые продукты, получаемые в ходе ядерно-топливного цикла, добычи и переработки урановых руд, производства ТВЭЛов и другие источники ионизирующего излучения. Отработанное ядерное топливо - промышленных и военных энергетических установок после хранения на полигонах подлежит регенерации. Ежегодно в мире вырабатывается около 10000 т высокоактивных отходов и более 200000 м3 жидких низкорадиоактивных отходов. Большая часть этих 
отходов подлежит захоронению в геологических формациях. При разработке урановых руд подземным способом на 1 г урановой руды приходится 1,5 - 1.6 т твердых радиоактивных отходов. Способами кучного выщелачивания возможно дополнительное извлечение урана из отвалов рудников, а способами подземного выщелачивания разрабатывают некондиционные руды и забалансовые руды действующих и законсервированных месторождений.

Вышеперечисленные техногенные минеральные объекты при положительной технико-экономической оценке и обосновании кондиций качества минеральной массы возможно рассматривать как техногенные месторождении. Отвалы рудников, эфеля обогатительных фабрик также рассматриваются в качестве техногенных руд в связи с уменьшением кондиционных показателей природных руд.

Особое внимание следует уделить отходам горнодобывающей промышленности, поскольку они накоплены в значительных количествах и занимают огромные площади. Эти ТМО не являются пока объектом массовой переработки на базе существующих технологий, хотя находятся в природном состоянии. Техногенные минеральные образования отвечают понятию нетрадиционных минеральных ресурсов.

Помимо уже сформированных в районах действующих горнодобывающих предприятий техногенных образований актуально исследование проблемы целенаправленно сформированных техногенных минеральных объектов.

Значительная часть техногенных минеральных образований на основании комплексного изучения их минерально-сырьевой ценности и возможности использования в промышленности может быть отнесена к техногенным месторождениям.

Среди минеральных ресурсов, обеспечивающих стабильное развитие минерально-сырьевой базы РК и ее экономическое состояние, важное значение имеют техногенные минеральные ресурсы. Они представлены техногенными месторождениями и техногенными минеральными образованиями. С учетом снижения качества руд, сокращения количества запасов в крупнейших горнорудных районах и ухудшения горно-геологических условий отработки месторождений, вовлечения в переработку ранее складированной горной массы техногенных ресурсов становится экономически выгодным. Наибольшую практическую применимость имеет классификация отходов по отраслям промышленности их образующим и классификации для отдельных видов отходов.

Техногенные минеральные образования, которые по количественным, качественным, технологическим и технико-экономическим показателям обеспечивают возможность и экономическую целесообразность их 
промышленного освоения, относятся к техногенным месторождениям полезных ископаемых.

Техногенные минеральные образования представляют собой горнопромышленные отходы в горнодобывающей, металлургической, топливноэнергетической и химической промышленности. Они характеризуются сложным внутренним строением, различаются по плотности, крупности обломков, вещественному составу, содержанию полезных компонентов и технологическим свойствам минерального сырья. Основная масса горнопромышленных отходов в Казахстане образуется в горнодобывающих предприятиях (72,5\%) при вскрышных и горнопроходческих работах, значительно меньше на обогатительных фабриках (25,7\%) и металлургических заводах 1,8\%).

Высокие темпы добычи и переработки минерального сырья привели к образованию большого количества горнопромышленных отходов. На предприятиях горнопромышленного производства Казахстана в отвалах и хвостохранилищах находится более 20 млрд. т техногенных минеральных образований. Ежегодно накапливается около 1 млрд. т и уровень использования техногенных минеральных образований в настоящее время является низким.

Горнопромышленные отходы обогатительных фабрик и металлургических заводов требуют специальных инженерных сооружений для хранения, а сами отходы содержат не только полезные, но и вредные компоненты, которые оказывают негативное влияние на окружающую природу. Техногенные минеральные образования занимают значительные площади земель сельского хозяйства, являются источником пыле - и газовыделений токсичных образований, загрязняют атмосферу, почву, поверхностные и подземные воды.

При разработке месторождений открытым и подземным способами в горнопромышленные отходы попадает значительная часть промышленного минерального сырья. При обогащении руд в концентраты извлекаются 75-85\% основных и 50-80\% сопутствующих компонентов, а остающаяся их часть теряется и складируется в отвалах (хвостах) обогащения. При металлургическом переделе извлечение основных компонентов составляет 80-95\%, остальные теряются и складируются в отвалы металлургических шлаков.

В техногенных минеральных образованиях накапливается значительное количество неизвлеченных полезных компонентов.

Горнопромышленные отходы содержат неизвлеченные полезные компоненты и они рассматриваются как потенциальные техногенные месторождения.

В зарубежных странах расширяется использование техногенных минеральных образований и этому способствует комплексное использование техногенного минерального сырья. 
Техногенные минеральные объекты по принадлежности к определенным отраслям промышленности, предприятиям горнопромышленного производства и способам формирования разделяются на пять типов:

1) техногенные минеральные объекты горнодобывающих предприятий, представленные отвалами вскрышных и рудовмещающих пород, забалансовых и некондиционных руд;

2) техногенные минеральные объекты обогатительных фабрик представляют собой отвалы (хвосты) обогащения;

3) техногенные минеральные объекты металлургических заводов, представленные металлургическими шлаками;

4) техногенные минеральные объекты химической промышленности представляют собой отходы химической переработки (шламы и др.);

5) техногенные минеральные объекты топливной энергетики представлены золошлаковыми отходами тепловых электростанций

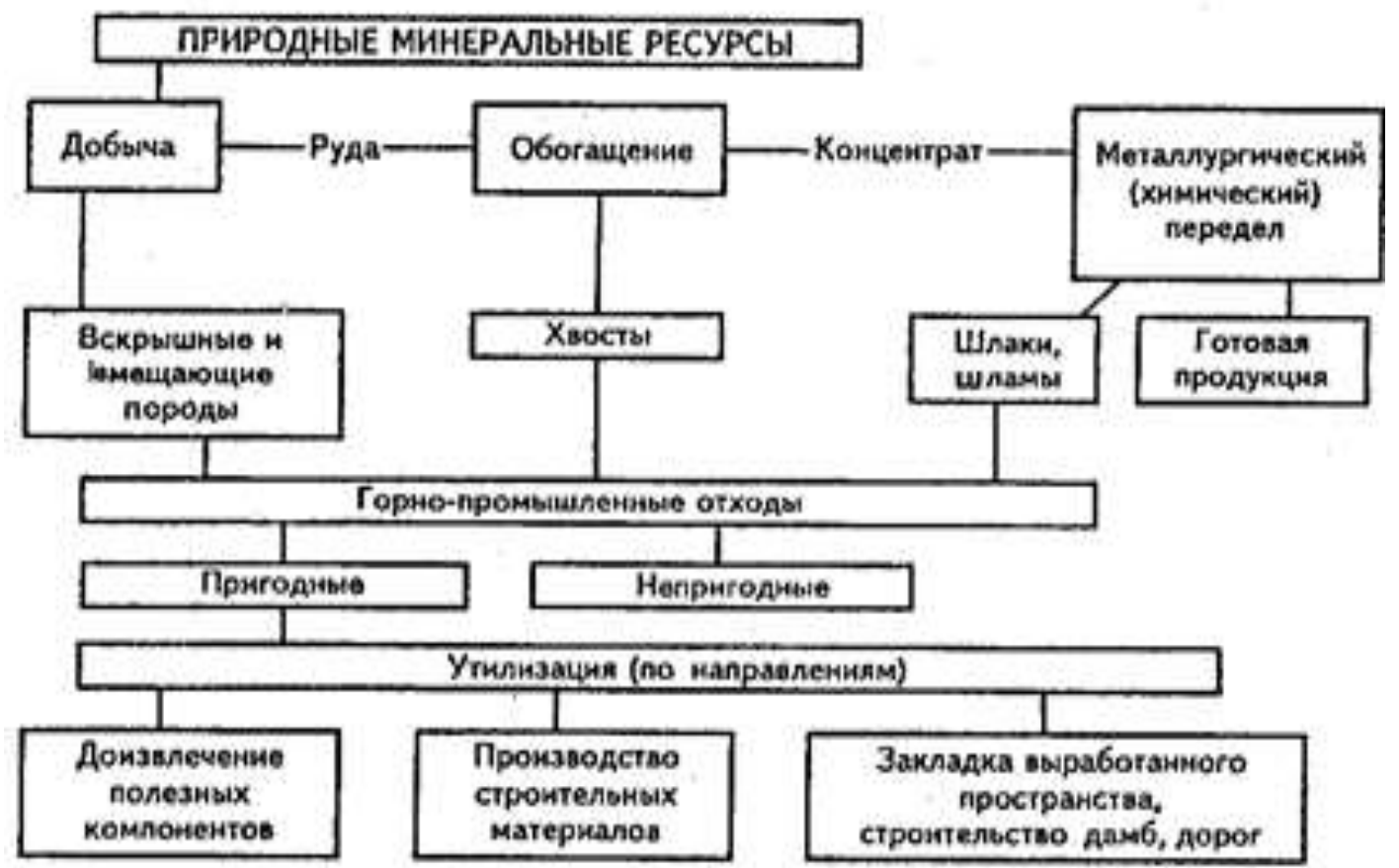

Рисунок 6. Схема формирования и использования горнопромышленных отходов

Техногенные минеральное сырье может использоваться для извлечения полезных компонентов, в качестве строительных материалов, минеральных удобрений и др.

Для промышленного освоения наибольший практический интерес представляют отходы обогащения металлургического производства, в которых содержится цветные, редкие и благородные металлы. Отходы обогащения руд, металлургические и шламы в основном применяют в качестве рудного сырья.

В качестве горнотехнического сырья используют хвосты обогащения, металлургические шлаки, золошлаковые отходы тепловых электростанций и 
отходы химической промышленности. Они применяются для доизвлечения ценных компонентов (баритов, асбеста, графита, флюорита, слюд, талька и др.) и производства флюсовых, формовочных и огнеупорных материалов.

В качестве агрохимического сырья техногенные минеральные образования используют для доизволечения ценных компонентов (апатита, фосфорита).

Техногенные минеральное сырье (шлаки, золошлаковые отходы, хвосты обогащения и др.) широко применяют в строительной индустрии для производства бетонов, цементов, строительных материалов.

Горнопромышленные отходы используют для засыпки карьеров, отсыпки дамб хвостохранилищ, в качестве закладочного материала при проходке подземных горных выработок, при дорожном строительстве.

Уровень использования горнопромышленных отходов в настоящее время является низким. Применение новых технологий комплексной переработки техногенного минерального сырья повышает возможности их промышленного освоения.

\section{2 Использование техногенного сырья в строительстве}

Техногенные минеральные образования (ТМО) - скопления минеральных веществ на поверхности Земли или в горных выработках, образовавшиеся в результате отделения их от природного массива и складирования в виде отходов горного, обогатительного и металлургического производств. Постоянное увеличение объемов образующихся в горнодобывающей и перерабатывающей промышленности различных видов отходов и складирования их в хранилищах и опыт использования таких объектов в промышленности позволяет рассматривать их как источники для получения вторичного сырья и строительных материалов.

Таблица 6. Отходы промышленности, используемые в производстве строительных материалов

\begin{tabular}{|l|l|}
\hline Отходы & Области применения и материалы \\
\hline $\begin{array}{l}\text { Шлаки черной металлургии: } \\
\text { доменные, мартеновские, } \\
\text { ферромарганцевые }\end{array}$ & $\begin{array}{l}\text { Портландцемент (производство клинкера), } \\
\text { портландцемент с минеральной добавкой, } \\
\text { шлакопортландцемент, смешанные бесцементные } \\
\text { вяжущие, заполнители для бетонов, шлаковая вата, } \\
\text { шлакоситаллы и т.д. }\end{array}$ \\
\hline $\begin{array}{l}\text { Отходы цветной металлургии: } \\
\text { шлаки (медеплавильных печей, } \\
\text { никелевого производства, } \\
\text { свинцовой шахтной плавки и }\end{array}$ & $\begin{array}{l}\text { Вяжущие автоклавного твердения, песок и щебень, } \\
\text { портландцемент (производство клинкера), } \\
\text { нефелиновый цемент, материалы для укрепления }\end{array}$ \\
\hline
\end{tabular}




\begin{tabular}{|c|c|}
\hline $\begin{array}{l}\text { т.д.), шламы (бокситовый, } \\
\text { нефелиновый, каолиновый) }\end{array}$ & $\begin{array}{l}\text { грунтов, огнеупоры, теплоизоляционные материалы и } \\
\text { т.д. }\end{array}$ \\
\hline $\begin{array}{l}\text { Золы и шлаки тепловых } \\
\text { электростанций }\end{array}$ & $\begin{array}{l}\text { Вяжущие, пористый гравий, газобетон, силикатные } \\
\text { изделия, добавки к керамике и т.п. }\end{array}$ \\
\hline $\begin{array}{l}\text { Вскрышные породы: вскрышные } \\
\text { и пустые породы, хвосты } \\
\text { обогашения и т.д. }\end{array}$ & $\begin{array}{l}\text { Портландцемент (производство клинкера), воздушная } \\
\text { известь, минеральная вата, стекло, пигменты, } \\
\text { керамический кирпич, силикатный кирпич, } \\
\text { заполнители для бетонов и т.д. }\end{array}$ \\
\hline $\begin{array}{l}\text { Отходы угледобычи и } \\
\text { углеобогащения: } \\
\text { коксохимических предприятий, } \\
\text { углеобогатительных фабрик, } \\
\text { шахтные негорелые породы }\end{array}$ & $\begin{array}{l}\text { Пористый заполнитель для бетона, керамический } \\
\text { кирпич, материалы для строительства дорог }\end{array}$ \\
\hline $\begin{array}{l}\text { Гипсовые отходы химической } \\
\text { промышленности: фосфогипс, } \\
\text { фторгипс, титаногипс, борогипс, } \\
\text { сульфогипс }\end{array}$ & Замена традиционного гипсового сырья \\
\hline $\begin{array}{l}\text { Отходы древесины и лесохимии: } \\
\text { кора, пни, вершины, ветви, } \\
\text { сучья, горбыль, стружки, щепа, } \\
\text { опилки, лигнин, скоп и т.д. }\end{array}$ & $\begin{array}{l}\text { Арболит, фибролит, ДВП, ДСП, столярные плиты, } \\
\text { опилкобетон, ксилолит, клееные изделия, щитовой } \\
\text { паркет, дрань, лигноуглеводные древесные пластики, } \\
\text { королит, блоки из сучков, плиты из цельной коры, } \\
\text { выгорающие добавки, пластифицирующие добавки, } \\
\text { отделочные материалы, кровельный картон и т.д. }\end{array}$ \\
\hline $\begin{array}{l}\text { Отходы промышленности } \\
\text { строительных материалов: } \\
\text { цементная пыль, каменная пыль, } \\
\text { крошка, кирпичный бой, } \\
\text { бракованный и старый бетон }\end{array}$ & $\begin{array}{l}\text { Портландцемент, заполнители для бетона, } \\
\text { минеральный наполнитель, добавки, смешанные } \\
\text { вяжущие вещества и т.д. }\end{array}$ \\
\hline Пиритные огарки & Портландцемент (корректирующая добавка) \\
\hline Электротермофосфорные шлаки & $\begin{array}{l}\text { Портландцемент (компонент сырьевой смеси), ШПЦ, } \\
\text { сульфатостойкий ШПЦ, литой щебень, шлаковая } \\
\text { пемза, стеновая керамика (компонент шихты) }\end{array}$ \\
\hline $\begin{array}{l}\text { Прочие отходы и вторичные } \\
\text { ресурсы: стекольный бой и } \\
\text { отходы стекла, макулатура, } \\
\text { тряпье, изношенные шины и т.д. }\end{array}$ & $\begin{array}{l}\text { Стекло, наполнитель для асфальта, добавка при } \\
\text { производстве стеновой керамики, пористый } \\
\text { заполнитель для бетона, кровельный картон, изол, } \\
\text { фольгоизол и т.д. }\end{array}$ \\
\hline
\end{tabular}

Использование техногенного сырья - мощный экологический ресурс.

В условиях нарастающей экологической напряженности в мире проблема рационального использования и эффективного сбережения природных ресурсов становится важнейшей задачей жизнедеятельности любого государства.

Исключительно важное значение имеет не только сбережение сырьевых ресурсов, но и их повторное использование. Значение вторичных сырьевых ресурсов для поддержания экологически безопасного уровня воздействия на окружающую среду весьма значительно, в частности, их использование является 
одним из необходимых условий внедрения малоотходных и безотходных технологий. Важную роль в утилизации (использовании) вторичных сырьевых ресурсов играет строительство и промышленность строительных материалов. Как известно, эти отрасли промышленности используют два вида сырья: природное и техногенное (вторичное).

Природное сырье - это строительные камни, песчано-гравийная смесь, гравий, песок, щебень и другие горные породы. Сюда же относят отвалы вскрышных пород, образующиеся при разработке карьеров и строительных котлованов

Техногенное сырье рассматривается многими специалистами как национальное достояние, как исключительно ценный продукт, аккумулирующий в себе ранее затраченные инвестиционные и энергетические ресурсы. Его использование в производстве строительных материалов во многих случаях оказалось значительно дешевле, чем разработка и освоение природных ресурсов. Использование техногенного сырья для производства строительных материалов с экологической точки зрения весьма перспективно:

1) резко сокращаются объемы добычи дефицитных природных строительных материалов;

2) утилизируется и химически прочно связывается огромное количество загрязняющих окружающую среду промышленных отходов;

3) освобождаются ценные земельные участки, отчуждаемые под хвосто- и шламохранилища и др. Только под хранение золошлаковых отходов ТЭС отчуждаются огромные территории. В строительной индустрии находят широкое применение многие виды промышленных отходов и побочных продуктов.

В строительной индустрии находят широкое применение многие виды промышленных отходов и побочных продуктов. Приводим несколько примеров их использования.

Зола и золошлаковые отходы (ЗШО). В настоящее время ежегодно образуются десятки миллионов тонн золошлаковых отходов. Каждые сутки работы на угле ТЭС накапливается до 1 тыс. т золы и шлака. Подавляющая их часть направляется в отвалы, а в строительной индустрии утилизируется лишь 3-5\% ЗШО. Для сравнения: в США и Германии — 40-60\%. В США из 20 млн т ежегодно образующихся зол уноса только для изготовления бетона утилизируется 7 млн т.

Золошлаковые отходы — незаменимый компонент формовочных смесей для получения высококачественных строительных материалов. Их используют для производства ячеистого бетона, силикатного кирпича, пенозолсиликата, 
аглопорита, асфальтового основания дорожных одежд и т. д. ЗШО считаются прекрасным цементосберегающим материалом. При производстве бетонов введение зол позволяет экономить до 100 кг/ $\mathrm{M}^{3}$ цемента, а при использовании добавок-модификаторов - до 200 кг/м ${ }^{3}$. Одновременно улучшается структура цементного теста и повышаются теплозащитные свойства конструкций.

Прекрасно зарекомендовала себя разработанная ВНИИстроем, безотходная технология производства лицевого кирпича на основе зол ТЭС, позволяющая не только сэкономить средства на строительство и эксплуатацию золоотвалов, но и значительно уменьшить загрязнение среды. По данным Л. С. Бариновой и Ю. С. Волкова , замена в бетоне или растворе $15 \%$-ного цемента на золу уноса или металлургический шлак, что технологически допускается, в перерасчете на мировые объемы их применения, могло бы снизить количество выбросов в атмосферу диоксида углерода $\left(\mathrm{CO}_{2}\right)$ на 300 млн т в год.

Металлургические шлаки- высококачественное сырье для производства шлакопортландцементов, шлаковаты, гипсошлаковых блоков, щебня и др. Годовой объем выхода шлаков металлургических заводов исчисляется многими десятками миллионов тонн. В нашей стране очень высок объем утилизации доменных шлаков, $80 \%$ выхода которых идет для изготовления шлакопортландцемента и пористых заполнителей.

В последние годы все большее применение в качестве крупного и мелкого заполнителя в бетонах получают создаваемые по безотходной технологии шлаковая пемза (термозит) и шлакостеклогранулят, не уступающие природному щебню по большинству показателей. Например, прочность бетона на шлаковом цементе на 15-20\% выше, чем на гранитном.

Широко известен ценнейший конструктивный материал - шлакоситалл, обладающий высокими физико-механическими, химическими свойствами и экологической чистотой. Исключительно большое значение для производства портландцементного клинкера и шлакопортландцементов высокого качества имеет гранулированный доменный шлак, придающий цементу антикоррозийность, повышенную прочность, текучесть и быстроту твердения.

В связи с тем, что в ближайшие годы в мире ожидается реконструкция предприятий по переработке отработанного ядерного топлива (ОЯТ), резко усиливается спрос на особо тяжелые бетоны для радиационной защиты. Для этих целей учеными предлагается использовать бетон, в составе которого вместо дорогостоящего металла будут использованы отходы и шихта металлургического производства. 


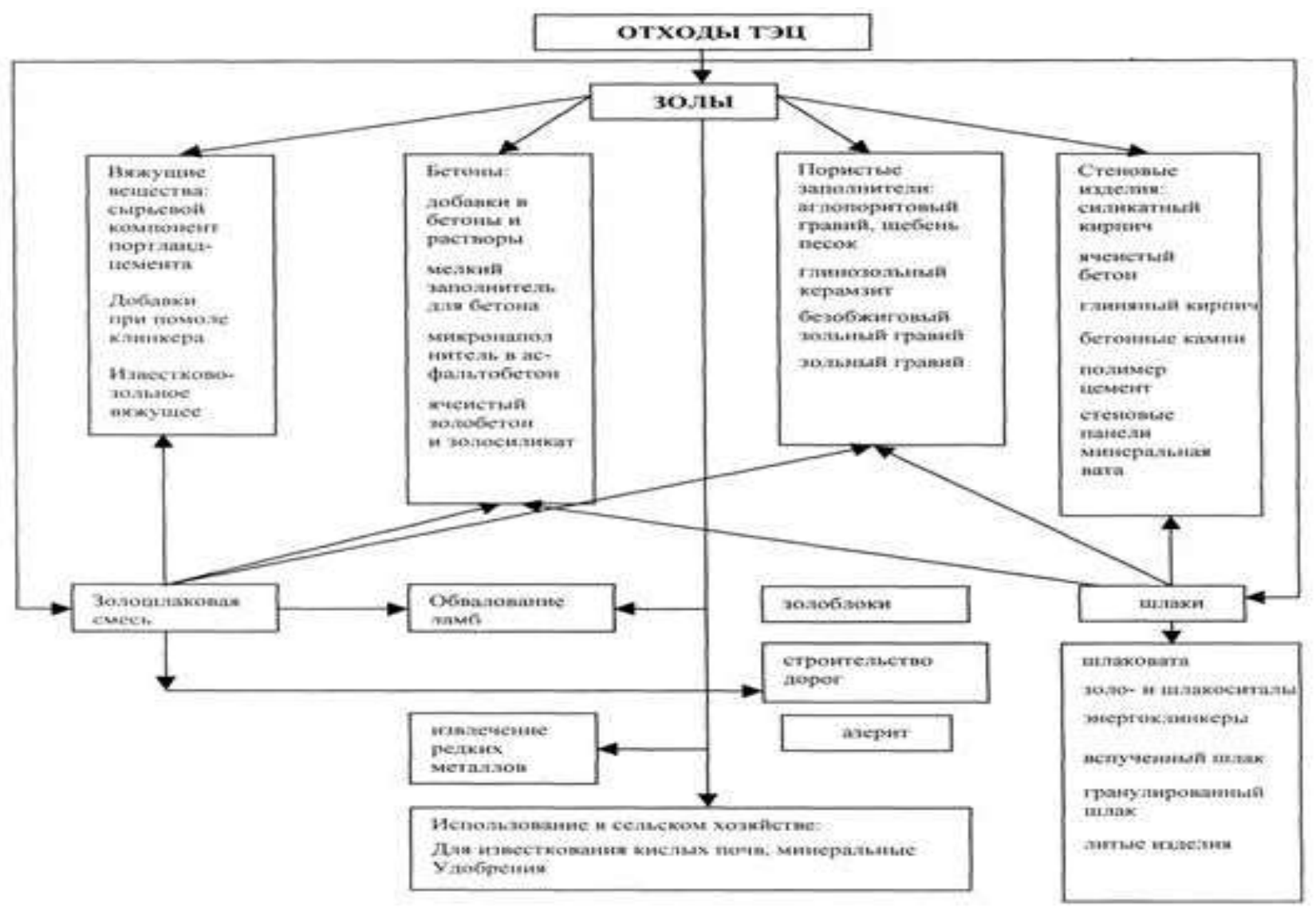

Рисунок 7. Схема использования золошлаковых отходов ТЭЦ

Прекрасным примером блокирования фенолформальдегидных и других загрязнителей в структуре строительных материалов является использование отработанных формовочных смесей (ОФС), образующихся в ходе металлургического литейного передела. Формовочная глина, используемая как связующее, нетоксична и может широко применяться при производстве строительных материалов.

Продукты переработки древесины и других растительных отходов. В мире на лесопромышленных комплексах и деревоперерабатывающих комбинатах ежегодно образуется свыше 200 млн м ${ }^{3}$ отходов древесины. Кроме того, сжигается и вывозится в отвалы в огромном количестве древесная тара, отходы переработки хлопчатника, лубяных культур и другого экологически ценного сырья, пригодного для производства строительных материалов.

По мнению В. И. Сметанина, важнейшим направлением рационального, экологически целесообразного использования древесины в строительной индустрии является производство различных древесных бетонов: арболита, фибролита, опилкобетона, королита и др.

Наиболее известным из этих экологически чистых дешевых строительных материалов является арболит. Это легкий крупнопористый бетон, состоящий из древесной дробилки (в основном отходы от лиственных пород) и 
портландцемента марки 400. Широко применяется в качестве стеновых блоков при строительстве малоэтажных зданий. При устройстве ограждающих конструкций и перегородок используют королит - теплоизоляционный материал, состоящий из коры, цемента (или строительного гипса) и добавок.

В промышленности строительных материалов широкое применение находит ценнейшее экологически чистое сырье, вырабатываемое из отходов целлюлозно-бумажного производства - лигносульфонаты, обладающие обеспыливающими, пластифицирующими, пенообразующими и другими ценными свойствами.

Отходы химического комплекса. Несмотря на огромные объемы и разнообразие видов вторичного минерального сырья, эти отходы в строительной индустрии используются недостаточно. Находят некоторое применение электротермофосфорные шлаки (илакопортландиемент, силикатный кирпич), отходы содового производства (автоклавное производство материалов, газогипс), кубовые остатки перегонных производств и битумы (ячеистые бетоны с добавками нефтебитума и др.).

С точки зрения экологии следует более подробно остановиться на побочном продукте, получаемом при переработке апатитовых и фосфоритовых концентратов - фосфогиnсе. Применяется он при изготовлении цемента, строительных блоков, сухой штукатурки и др. Только в Японии в 70-х гг. строительная промышленность ежегодно расходовала около 3 млн т фосфогипса.

Помимо рассмотренных выше золошлаковых отходов, металлургических шлаков, продуктов переработки древесины и отходов химического производства при производстве строительных материалов находят применение и другие виды техногенного сырья. Важно подчеркнуть, что практически для любого вида выпускаемых строительных материалов вместо природного сырья возможно и экологически целесообразно использование различных видов техногенного сырья.

Техногенным сырьем для производства пористых заполнителей являются вскрышные породы месторождений целого ряда полезных ископаемых, а также различные шлаки и отходы углеобогащения.

Во вскрышных породах наиболее распространено керамзитовое сырье. Оно установлено на месторождениях очень многих видов полезных ископаемых - карбонатных пород разного назначения, огнеупорных, бентонитовых глин, бурого и каменного угля, фосфоритов, бокситов, формовочных песков, железистых кварцитов, марганцевых, сурьмяно-ртутных, кобальтсодержащих магнетитовых руд и др. Однако, как и в других подотраслях промышленности 
строительных материалов, вскрышные породы утилизируются мало и изучены слабо.

Утвержденные запасы керамзитовых глин во вскрышных породах на действующих горнодобывающих предприятиях имеются лишь на шести месторождениях: Назаровском (уголь) в Красноярском крае, Междуреченском (песок строительный) в Приморском, Черкасском (бентонит) на Украине, Соколовско-Сарбайском (железные руды), Восточно-Аятском и Дарбазинском (бентонит) в Казахстане. Суммарные запасы керамзитовых глин, на всех перечисленных месторождениях составляют менее 2 \% всех разведанных запасов.

Слабо утилизируются также металлургические шлаки, золошлаковые отходы ТЭЦ, хвосты углеобогащения, хотя специалисты считают, что в перспективе это сырье должно стать основным, отодвинув на второй план керамзитовые глины.

Отходы углеобогащения относятся в основном к невспучивающимся или слабовспучивающимся породам, поэтому их целесообразно использовать прежде всего для производства аглопорита. Предпочтительны для этого отходы гравитационного обогащения углей. От обычных глин отходы углеобогащения отличаются более высокой прочностью и меньшей влажностью.

В настоящее время разработан целый ряд технологий производства пористых заполнителей из различных промышленных отходов: из золы с небольшой добавкой отходов флотации углей, из шламов глиноземного производства и др. Такие технологии позволяют организовать производство пористых заполнителей практически в любом промышленном районе страны. Требуемые для этого большие энергетические затраты могут быть компенсированы высокой эффективностью применения пористых заполнителей (облегчение строительных конструкций и сокращение теплопотерь в зданиях).

Практический интерес могут представлять гидратированные слюды отходы обогащения, скопившиеся в отвалах разрабатываемых месторождений электротехнических мусковитов. Однако пока еще отечественное производство пористых заполнителей базируется в основном на природном сырье.

Разведанные запасы всех видов природного сырья составляют 4,4 млрд. $\mathbf{m}^{3}$, из них по видам: керамзитовые и аглопоритовые глины 2,8; пемзы, туфы и другие породы, пригодные в качестве природных пористых заполнителей 0,8; перлиты $\mathbf{0 , 3}$; опал-кристобалитовые породы, пригодные для производства термолита и трепелозита, - 0,4 млрд. ${ }^{3}$, вермикулит - 25 млн. т. Около половины учтенных балансом месторождений мелкие (менее 1 млн. ${ }^{3}$ ).

Добывается ежегодно для производства пористых заполнителей 35 млн. м², в том числе керамзитовых глин 20, трепелов 4,5, перлита 3,5, пород с 
естественной высокой пористостью 7, шунгизитовых сланцев 0,2 млн. м², вермикулита - 0,1 млн.т.

Другие виды природного сырья для производства пористых заполнителей распространены более локально. Пемзы, туфы и другие породы с высокой естественной пористостью, а также вспучивающиеся вулканические стекла и эффузивы (перлит, обсидиан, липарит) тяготеют к складчатым, преимущественно молодым областям.

В целом обеспеченность существующего и намечаемого производства пористых заполнителей высокая. Тем не менее, некоторые предприятия не имеют достаточно надежной сырьевой базы.

Ряд заводов работает на неразведанном или неоцененном для производства пористых заполнителей сырье.

Таким образом, состояние обеспеченности производства пористых заполнителей природным минеральным сырьем нельзя считать благополучным. В то же время расширение использования различных видов техногенного сырья, освоение новых технологий позволили бы значительно увеличить выпуск пористых заполнителей, улучшить их качество, разнообразить ассортимент и создать в каждом промышленном районе собственное производство.

\section{3 Вторичное минеральное сырье и его характеристика}

Вторичное сырье - используемые в производстве вещества и материалы, являющиеся невостребованными в других производствах. Источниками их являются отходы производства и отходы потребления. Отходы производства - остатки сырья и вспомогательных материалов, которые утратили свои первоначальные качества, а также продукты, не являющиеся целью производственного процесса (дополнительные продукты). Отходы потребления - бывшие в употреблении вещества и изделия, восстановление которых экономически нецелесообразно. Основные пути их использования в промышленном производстве следующие:

- извлечение, регенерация непрореагировавшего сырья и материалов и возврат в производство;

- извлечение ценных компонентов как продуктов производства;

- выделение компонентов и придание им с помощью специальных операций товарной ценности;

-использование отходов как исходных веществ и материалов в других производствах или других отраслях промышленности.

Во всех случаях предполагается одно из двух назначений вторичного сырья как исходного компонента: 
-вторичное сырье частично или даже полностью заменяет первичное в каком-либо производстве;

- на основе вторичного сырья создастся новый химико-технологический прочесс, отличный от применяемого в производстве того же продукта на основе первичного сырья .

Агрегатное состояние сырья определяет в основном методы его транспортировки и подготовки к переработке. Добываемое из недр Земли сырье кроме целевых компонентов содержит бесполезные (пустая порода) и вредные примеси.

В большинстве случаев содержание примесей относительно велико, поэтому приходится проводить обогащение сырья: оно необходимо для уменьшения затрат на переработку сырья, улучшает качество продукта и уменьшает расходы на транспорт сырья к месту производства.

\section{4 Значение вторичного сырья для производства строительных материалов и экологии}

Целесообразность применения отходов продиктована двумя основными факторами: необходимостью улучшения экологической обстановки; разработкой ресурсо- и энергосберегающих технологий, снижением себестоимости продукции. В современных условиях особое значение для эффективного развития народного хозяйства имеет проблема более широкого вовлечения в производство образующихся отходов, что позволяет расширить сырьевую базу и снизить загрязнение окружающей среды. Достаточно эффективно и в значительных объемах образующиеся отходы могут потреблять такие отрасли, как строительство и промышленность строительных материалов).

В качестве примера идентичности использования различных по свойствам сырья и отходов можно привести тот факт, что вскрышные породы, образующиеся при добыче горнохимического сырья, каменных, бурых углей и ряда руд черных металлов, могут найти широкое применение для производства различных строительных и вяжущих материалов.

Технические гидролизные лигнины и некоторые виды угольных отходов могут использоваться в качестве топлива, углеродистых восстановителей для ряда металлургических производств, в качестве адсорбентов для очистки сточных вод, обезвреживания газовых выбросов и др.

В настоящее время на основе отходов различных отраслей, предприятия строительных материалов выпускают изделия и материалы должного качества, причем с меньшими затратами на производство, чем при использовании 
первичного сырья, так как исключаются расходы на добычу, транспортирование, обработку сырья.

В современных условиях одной из важнейших задач является широкое использование вторичных сырьевых материалов. Промышленностью строительных материалов накоплен положительный опыт использования отходов, как сырья для производства эффективных строительных материалов, не уступающих по качеству изделиям, полученным при использовании первичного сырья.

Из отходов древесины, полученных на различных стадиях ее переработки, изготовляют древесно-волокнистые и древесно-стружечные плиты, арболит, ксилолит, опилкобетон, ксилобетон, фибролит, королит, древеснье пластики.

Применение материалов на основе древесных отходов, наряду с высокими технико-экономическими показателями, обеспечивает архитектурную выразительность, хороший воздухообмен и микроклимат помещений, улучшенные теплотехнические показатели.

Комплексное использование сырья и отходов важно еще и потому, что оно связано с решением проблемы создания безотходных и экологически чистых промышленных технологий.

Разработка и освоение безотходных технологий имеют важное значение для предприятий химической, горнохимической, микробиологической, металлургической, угольной, строительной и других ресурсоемких отраслей промышленности. 


\section{3 МИНЕРАЛЬНОЕ СЫРЬЕ ДЛЯ ПРОИЗВОДСТВА ЦЕМЕНТА}

По запасам и добыче цементного сырья (известняки, глинистые породы) Казахстан занимает ведущее место среди стран СНГ. По промышленным категориям разведано более 2 млрд.т.

К наиболее крупным относятся месторождения: Сарыапак, Астаховское, Шекубаевское, Коксорское, Агалатасское и др.

Месторождения цементного сырья имеются в Карагандинской, ВосточноКазахстанской и Шымкентской областях, где работают крупные цементные заводы. Разведаны запасы цементных известняков в Павлодарской и Жамбылской областях, где намечается строительство новых цементных заводов.

Для производства цемента используются карбонатные и глинистые породы, сырье с другим природным составом, а также промышленные отходы.

К карбонатам относят мел, известняк, мергелистый известняк, и, конечно, известняк-ракушечник. Также в этой группу входят горные породы осадочного и метаморфического типа с известняковым, доломитовым и карбонатноглинистым составом. Их ценность непосредственно зависит от их структуры и физических свойств.

Структура цемента напрямую зависит от используемого сырья. Любая работа с использованием скрепляющих основ, например, требует особого цемента с определенными свойствами. Поэтому очень важно учитывать состав цемента перед непосредственной работой с ним.

Для примера, породы с кристаллической структурой уступают по своим качествам материалам с аморфной структурой. К тому же последние лучше взаимодействуют с веществами при процессе обжига.

Мел - это легко растираемая известняковая горная осадочная порода. Переходной формой породы является мергель. Этот материал может различаться по структуре, влажности и плотности. Изготовленные из него растворы используются для кладки каминов и печей.

Наиболее подходящие для цемента материалы из известняковых пород подходят мергелистые и пористые виды карбонатов, не содержащие кремния.

На производстве применяют некоторые виды горных пород: глина, лесс, суглинок, лессовидные суглинки и глинистый сланец. Минералы, входящие в состав глины, разбухают при взаимодействии с водой и становятся весьма пластичными. Их используют при сухом производстве, для получения гранулированного шлама.

В суглинках значительно больше, чем в глинах содержатся пылеватые и глинистые частицы. В глинистых сланцах меньше влаги и состав веществ более или менее постоянен. 
Лесс представляет собой пористую и рыхлую горную породу. В ней содержится значительное количество полевого шпата, кварца, и других силикатов. Его пластичность невысока. Между суглинком и лессом переходным материалом является лессовидный суглинок.

\section{1 Карбонатные породы}

Карбонатные породы, то есть образования, сложенные главным образом карбонатами кальция, магния и в меньшей степени железа, широко распространены в земной коре, составляя более $15 \%$ ее массы. Это в первую очередь различные известняки, мергели и мраморы, а также травертины, известковая гажа, жильные карбонатные породы, карбонатиты, карбонатные пески и другие образования. В их составе помимо собственно карбонатов в подчиненном количестве нередко присутствуют глинистые частицы, углистое вещество, кварц, полевые шпаты, сульфиды, сульфаты, хлорит, глауконит и многие другие образования.

Породы характеризуются большим разнообразием структур и текстур; помимо господствующих осадочных образований среди них имеются представители метаморфического (мраморы), магматического (карбонатиты), гидротермального (карбонатные жилы выполнения, травертины) и гидротермально-метасоматического (доломиты) генезиса. Осадочные карбонатные породы могут быть образованы в морских, лагунных и озерных условиях хемогенным и кластогенным путем.

Наибольшее значение для цементной промышленности имеют самые распространенные карбонатные породы, входящие в состав двух рядов: известняк $\mathrm{CaCO}_{3}$ - доломит $\mathrm{CaMg}\left(\mathrm{CO}_{3}\right)_{2}$ и карбонатная порода - глина. В первом ряду между указанными крайними членами фиксируется большое количество переходных разновидностей, отличающихся содержанием $\mathrm{MgO}$, во втором - наблюдается не менее широкое разнообразие сочетаний карбонатной и глинистой составляющих породы, причем карбонатная может быть представлена любыми членами ряда известняк - доломит, что приводит к появлению переходных между глинами, известняками и доломитами пород.

\section{2 Глинистые породы}

К глинам принято относить тонкодисперсные горные породы с преобладающим пелитовым (до 1 мкм) размером частиц, сложенные преимущественно различными глинистыми минералами с подчиненным количеством обломков горных пород, кварца, полевых шпатов, амфиболов, 
пироксенов, слюд и других минералов, а также органического вещества и аутигенных зерен карбонатного, сульфатного, фосфатного состава и др.

Большинство глин являются пластичными, то есть способными образовывать с водой пластичное тесто, сохраняющее при высыхании приданную ему форму и становящееся камнеподобным после обжига. Однако существуют и неразмокающие, так называемые сухарные глины, или флинтклей, а также аргиллиты и глинистые сланцы, которые подобно глинам обладают тонкодисперсным строением, близким минеральным и химическим составом. Вместе с глинами они объединяются в глинистые породы. К последним принято относить также лессы и суглинки. Промежуточными образованиями между глинами и карбонатными породами являются мергели, содержащие 50-70\% карбонатной составляющей.

По размерам слагающих породу частиц преобладающей фракции 5-1, 1-0,2 и менее 0,2 мкм различают крупно-, средне- и тонкозернистые (коллоидные) глины.

Глинистые минералы, слагающие основную массу породы, представляют собой относительно стабильные водные силикаты алюминия, железа и магния слоистой, слоисто-ленточной и смешанно-слоистой структур, отличающиеся от других силикатов высокой дисперсностью, гидрофильностью, способностью к сорбции и ионному обмену.

\section{3. Кремнистые кристобалит-опаловые породы}

К кремнистым кристобалит-опаловым горным породам относятся широко распространенные диатомиты, трепелы и опоки, а также более редкие спонголиты, радиоляриты и силико-флагеллиты. Эти породы осадочного биохимического происхождения представляют собой в различной степени уплотненные кремнистые остатки диатомей, радиолярий и игл губок, сложенных опалом и халцедоном. Содержание в них кремнезема составляет 6098\%; остальное приходится на глинистые минералы.

В диатомитах - легких, пористых, слабо сцементированных светлых почти белых породах - наблюдаются неразложившиеся кремнистые органические остатки и очень небольшое количество примесей в виде глинистых минералов, кварца и глауконита.

В светлоокрашенных трепелах эти остатки несут следы химического разложения, уступая место продуктам их преобразования - слабо сцементированным тельцам округлой формы; в них уже больше примесных, в основном аутигенных минералов (гидроксиды железа, глинистые минералы и др.). 
В отличие от диатомитов и трепелов опоки являются темно-серыми плотными породами, хотя и обладающими довольно высокой пористостью; в массе опалового микросферолитового материала органические остатки практически не устанавливаются; значительно больше глинистых и других аутигенных минералов.

Промышленное значение этих пород обусловлено их высокой гидравлической активностью (измеряется количеством извести СаO, поглощенной из раствора 1 г породы), малой объемной массой, высокой пористостью, фильтрационными, сорбционными каталитическими, звуко- и теплоизоляционными, абразивными и другими свойствами.

В нашей стране их подавляющая часть используется при производстве цемента в качестве гидравлических активных добавок: в отличие от других кремнистых (кварцевых, кварц-халцедоновых и халцедоновых) пород, кристобалит-опаловые содержат активный кремнезем, связывающий в бетоне избыточную свободную известь.

Остальная часть используется главным образом в строительстве для производства теплоизоляционных изделий, а также легкого искусственного заполнителя бетона - термолита, имеющего объемную массу 25-900 кг/ $\mathbf{M}^{3}$ и получаемого при термической обработке диатомитов и трепелов.

При оценке качества диатомитов, трепелов и опок как цементного сырья определяют их химический состав и гидравлическую активность. Массовая доля $\mathrm{SiO}_{2}$ в породе должна быть более $80 \%, \mathrm{CaO}$ - менее 2\%, $\mathrm{Al}_{2} \mathrm{O}_{3}$ - до 8\%. Гидравлическая активность, как количество поглощенной $\mathrm{CaO}$ за 30 суток, должна быть не ниже 150 мг/г.

Помимо диатомитов, трепелов и опок в качестве активных добавок в цемент могут использоваться вулканические породы опал-кристобалитового ряда: nуц̧цуоланы - слабо сцементированные вулканические пески и пепел и трассы те же, но уже уплотненные образования. Они также содержат в своем составе активный кремнезем; их гидравлическая активность при тех же условиях должна превышать 50 мг/г.

\section{4 Сульфатные породы}

Ангидрит $\mathrm{CaSO}_{4}$ и гипс $\mathrm{CaSO}_{4} \cdot 2 \mathrm{H}_{2} \mathrm{O}$ являются широко распространенными сульфатами, образующими кристаллические гранулярные либо волокнистые агрегаты. Более редкими разновидностями гипса являются тонкозернистый просвечивающий агрегат - алебастр и тонковолокнистый агрегат с шелковистым блеском - селенит. Оба минерала белые и светло-серые; по сравнению с гипсом ангидрит часто имеет голубоватый оттенок, заметно 
более высокую твердость $(3-3,5)$ и больший удельный вес $(2,93$ по сравнению с

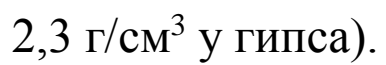

Основная масса этих минералов входит в состав одноименных мономинеральных горных пород, содержащих также примеси карбонатов, галита, кварца, глинистых и других минералов. Гипс, кроме того, совместно с песчаным, алевритистым, глинистым и известковым материалом образует своеобразные породы (гажу), содержащие иногда значительное количество гальки и гравия.

При нагревании до температуры $120-180^{\circ} \mathrm{C}$ гипс теряет часть своей воды и переходит в полугидрат $\mathrm{CaSO}_{4} 0,5 \mathrm{H}_{2} \mathrm{O}$ или полуводный гипс. Этот продукт, называемый часто строительным гипсом, при смешивании с водой образует высокопрочное вяжущее вещество, быстро схватывающееся и твердеющее. Его широко используют для штукатурных и отделочных работ, изготовления всевозможных строительных конструкций, а также в качестве формовочного материала и медицинского гипса.

Обжиг ангидрита и гипса при температурах $800-1000^{\circ} \mathrm{C}$ приводит к частичной диссоциации $\mathrm{CaSO}_{4}$ с образованием небольшого количества (до 3\%) свободной жженой извести СаО. Это так называемый кальцинированный или эстрихгипс; он медленно соединяется с водой, превращаясь в вяжущую массу, широко используемую в строительстве для производства плиточных и бесшовных полов, лестничных ступеней, искусственного мрамора.

В цементной промышленности при производстве портландцемента гипс добавляется (до 3\%) в естественном виде для регулирования сроков схватывания бетона. Он используется также для получения гидравлического гипсошлакового цемента, представляющего тонко измельченную смесь высушенного гранулированного доменного шлака (80-85\%), гипса и портландцементного клинкера; этот цемент весьма эффективен при подземном и подводном строительстве в агрессивных сульфатных средах. Наконец, существует ангидритовый цемент, получаемый обжигом природного гипса при температурах $600-700^{\circ} \mathrm{C}$ с последующим тонким помолом вместе с различными активизирующими добавками.

В настоящее время около 90\% добываемых гипса и ангидрита используется в качестве сырья для производства гипсовых вяжущих веществ и цемента. Из других областей применения этих минералов следует упомянуть производство серной кислоты, некоторых азотных удобрений, гипсования засоленных почв, в качестве облицовочного материала (алебастр) и поделочного камня (селенит и алебастр).

В забоях карьеров и подземных горных выработок гипсовый и гипсангидритовый камень добывается преимущественно в виде кускового материала; 
его потери при прокаливании до температуры $600^{\circ} \mathrm{C}$ должны быть не менее 19 и не более $21 \%$.

Товарный гипсовый камень, используемый для производства вяжущих веществ, подразделяется на 4 сорта по минимально допустимым массовым долям $\mathrm{CaSO}_{4} \cdot 0,5 \mathrm{H}_{2} \mathrm{O}(\%): 95,90,80$ и 70, а гипс-ангидритовый камень - на 3 сорта: 95, 90 и 80.

Гипсовый камень используется как для производства гипсовых вяжущих материалов, так и цемента, в то время как гипс-ангидритовый - только цемента. При этом цементное производство использует фракцию камня 0-60 мм, а производство гипсовых вяжущих веществ - более крупную фракцию 60-300 мм.

Минерально-сырьевая база гипса и ангидрита в Казахстане достаточна для создания промышленности по выпуску гипсовой продукции для строительства, цементной и бумажной промышленности.

В Южном Казахстане находятся месторождения гипса и ангидрита: Улькентау, Боганале, Карагайлы, Илийское и др.

В Центральном Казахстане расположены месторождения: Маманское, Кокдомбак и Каражал.

В Западном Казахстане известны месторождения гипса: Индерское, Чернореченское, Акташское. 


\section{4 СЫРЬЕ ДЛЯ ПРОИЗВОДСТВА МИНЕРАЛЬНЫХ ВЯЖУЩИХ}

ВЕЩЕСТВ

\section{Минеральными или неорганическими вяжущими веществами} называются порошкообразные минеральные материалы, которые при смешивании с водой или водными растворами некоторых солей образуют тесто (пластическую массу), способное со временем отвердевать, превращаясь в камневидное тело.

Bce неорганические вяжущие вещества являются продуктами обжига соответствующего минерального сырья, т. е. они относятся к обжиговым строительным материалам. Однако ИСК (искусственные строительные камни), получаемые на их основе, относятся к безобжиговым, так как процесс их отвердевания происходит в условиях обычных температур.

Эту группу вяжущих разделяют на воздушные и гидравлические. Воздушные способны в тестообразном состоянии твердеть и длительно сохранять свою прочность только на воздухе, поэтому они применяются в наземных сооружениях, не подвергающихся воздействию воды. $\mathrm{K}$ ним относятся строительная воздушная известь, гипсовые, магнезиальные вяжущие вещества и жидкое стекло. Гидравлические вяжущие вещества способны после предварительного твердения на воздухе продолжать твердеть и в воде, увеличивая со временем свою прочность. Они могут применяться в

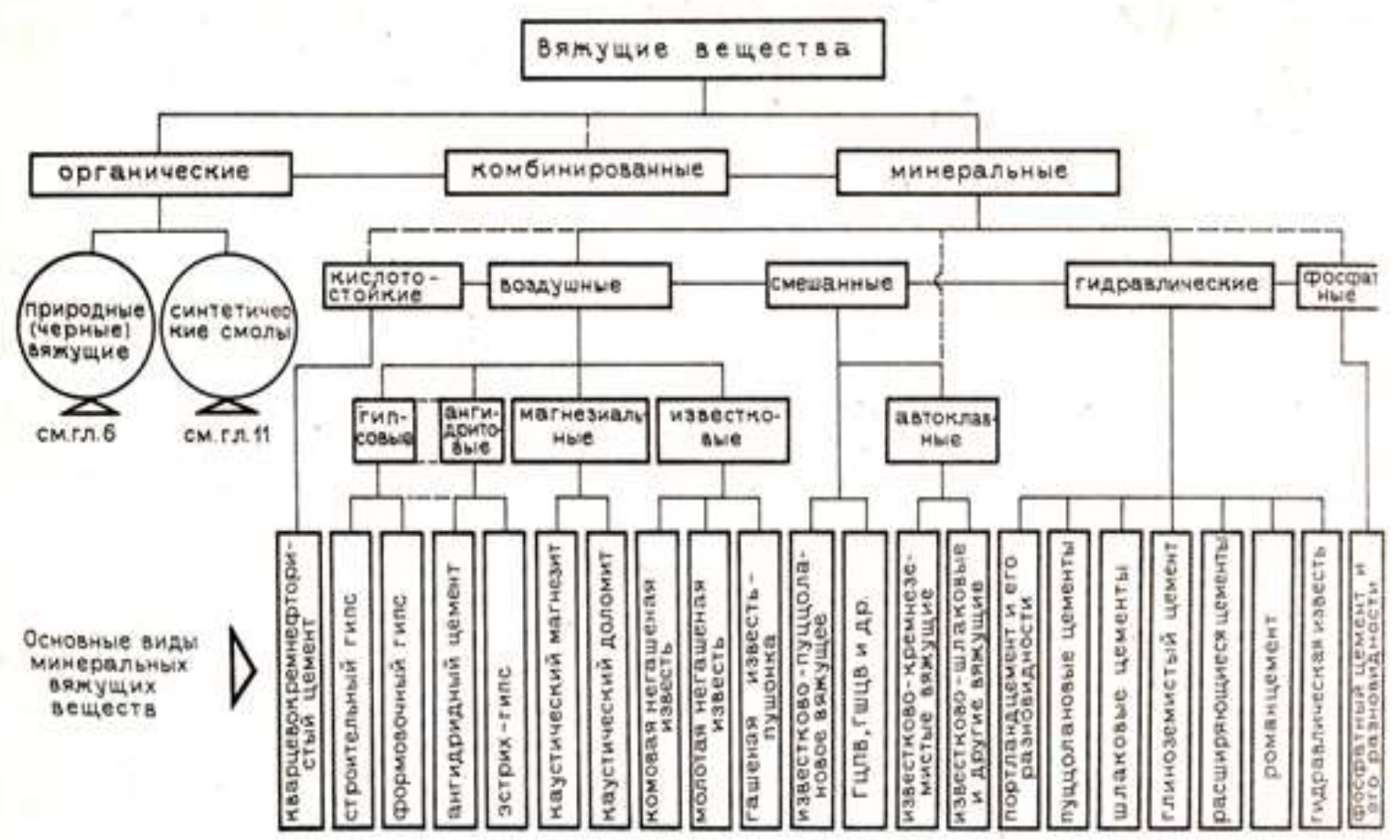

Рисунок 8. Классификация вяжущих веществ 
наземных, подземных, гидротехнических и других сооружениях, подвергающихся воздействию воды. Среди них портландцемент, глиноземистый цемент, шлаковые и пуццолановые смешанные цементы, ряд специальных цементов, а также гидравлическая известь. В отдельную группу нередко выделяют вяжущие вещества, которые наиболее эффективно твердеют при автоклавной обработке с повышенным давлением пара и при высокой температуре. К таким относят известково-кремнеземистые, известковошлаковые, известково-нефелиновые, песчанистые портландцементы и некоторые другие.

Сырьевой базой для производства неорганических вяжущих веществ являются горные породы и побочные продукты промышленности. Среди горных пород для этих целей используют сульфатныле - гunc и ангидрит; карбонатные - известняк, мел, известковые туфы, ракушечник, мрамор, доломиты, доломитизированные известняки, магнезит; мергелистые известковые мергели; алюмосиликатные - нефелины, глины, глинистые сланцьы; высокоглиноземистое сырье - бокситы, корунды и др.; кремнеземистые горные породы - кварцуевый песок, трассы, вулканический пепел (пуцуцолана), диатомит, трепел, опока.

Среди побочных продуктов в цементной промышленности находят применение главным образом илаки металлургические и золь, особенно илаки первичных (доменные) и передельных (мартеновские) прочессов, а такље илаки цзветной металлургии, топливные и др. По химическому составу они делятся на основные и кислье.

Часто вносят в сырье вещества в виде активных минеральных добавок, как природных, например диатомит, трепел, опоку, трасс, пуцущолану, пемзу, туф вулканический, так и искусственных - нефелиновый шлам, цемянку, глиеж (горелье nороды), золь, илаки. Нередко для получения вяжущих используют наполнители - тонко-измельченные кварцевый песок, известняк, доломит, андезит, диабаз, базальт, некоторые шлаки; поверхностно-активные добавки: гидрофильные - ЛСТ и ее аналоги (лигносульфонаты технические- отходы целлюлозно-бумажной промышленности) и гидрофобные - мылонафт, асидол, омыленный пек, олеиновая кислота и др.; ускорители твердения - хлористый кальций и хлористый натрий, соляная кислота, жидкое стекло, нитрит натрия и др.; замедлители твердения - двуводный гипс, серная кислота, сернокислое железо, клеи, ЛСТ; пластификаторы для улучшения формовочных свойств сырьевого материала - глина, бентонит, трепел, диатомит; интенсифицирующие добавки (при помоле) -антрацит и др.

Сырье бывает одно- и многокомпонентным, составленным из нескольких исходных веществ. При многокомпонентном сырье для лучшего перемешивания 
и получения более однородной смеси компоненты предварительно совместно или по отдельности измельчают. После полного цикла подготовки сырья дробления, помола, смачивания, корректирования состава - смесь подвергается термической обработке, или обжигу. При обжиге сырье теряет свободную воду, затем дегидратируется, отдавая химически связанную воду, и диссоциирует, распадаясь на отдельные оксиды. При последующем повышении температуры происходят реакции в твердом состоянии. Сырье изменяет свой химический состав, так как молекулы приходят в состояние с повышенной кинетической энергией - увеличиваются амплитуды и частоты тепловых колебаний: атомы или молекулы одного компонента как бы «отскакивают» со своей кристаллической решетки и присоединяются к атомам и молекулам другого реагирующего компонента при их близком соприкасании. 


\section{5 МИНЕРАЛЬНЫЕ ПИГМЕНТЫ}

В Казахстане выявлены месторождения и многочисленные проявления минеральных (природных) пигментов различного состава и назначения (сурик, охра и др.). Большая часть месторождений представлена железными шляпами, образовавшимися при химическом выветривании и окислении колчеданных и сидеритовых руд. Разведанными и наиболее крупными являются месторождения: Абаилское, Кубрексайское, Сугатовское, Черногорское и др.

Минеральные пигменты: железистые и марганцовистожелезистые охры, волконскоит, киноварь, барит, графит, тальк, пирофиллит, волластонит, природная сажа, карбонатные породы, азурит, глауконит и др.

К минеральным пигментам принадлежат различные горные породы и минералы, обладающие характерной окраской и достаточной устойчивостью.

Согласно Б. В. Залесскому и Ю. А. Розанову, выделяются следующие типы минеральных пигментов: железооксидный и марганиево-железооксидныгй, глинистый, углистый (сажистый), карбонатный, кремнеземистый, сульфатный, фосфорнокислый. Кроме того, существуют переходные разности (железооксидно-глинистый и др.).

Железооксидные и марганцево-железооксидные пигменты; по цвету разделяются на желтые (охра), коричнево-желтые (сиена), красные (мумия, железный сурик), коричнево-красные. Хромофорами в этой группе служат оксиды и гидроксиды $\mathrm{Fe}$ и, в меньшей мере, Мп, массовая доля которых составляет $30-85 \%$.

Глинистые пигменты - окрашенные оксидами и гидроксидами $\mathrm{Fe}$ и Мп различные глины и каолины, а также некоторые неокрашенные (белые) или окрашенные другими красителями (серые, черные и др.) глинистые породы. Массовая доля оксидов и гидроксидов (хромофоров) в пигментах данной группы колеблется от 0 до 30\%. Глинистым пигментом является продукт выветривания марганецсодержащих железных руд - умбра, имеющая коричневый с зеленоватым оттенком цвет. Чем больше в ней марганца, тем она темнее. При нагревании умбра темнеет. Это ее свойство используют для получения пигмента «прокаленная умбра». К этой группе пигментов принадлежит также «болюс» окрашенная гидроксидами железа монтмориллонитовая глина, используемая в качестве красной краски во Франции. Серая или черная окраска глинистых пигментов связана обычно с органическим веществом.

Карбонатные пигменты - мел и известняк вообще, мелоподобный мергель, доломит. Окраска их белая, светло-желтая (гидроксиды Fe), светлозеленая (глауконит), коричневая (гумусовые вещества). К особо ценным карбонатным пигментам относятся малахит и азурит. 
Углистые пигменты - продукты неполного сгорания или выветривания каменных углей. Окраска их черная (природная сажа), коричневато-черная, коричневая - обусловлена органическими веществами и частично оксидами железа. К углистым пигментам относится широко известный графит.

Кремнеземистые пигменты объединяют следующие минералы: луковозеленый волконскоит (Mg, Ca, C2, Al)a,(OH)2 [Si4O10] - nH20, зеленые глауконит, селадонит и гарниерит, синий лазурит, бельге волластонит, тальк, пирофиллит. К этой группе пигментов принадлежат и горные породы: белые диатомиты, розовые и красные вулканические туфы, темно-серые и цветные (зеленые, красновато-серые и др.) глинистые сланцы и другие кремнеземсодержащие разности.

Сульфатные пигменты-сульфатные минералы (белый барит, желтый ярозит) и горные породы (гипс и ангидрит).

Фосфорнокислые пигменты неустойчивы. Например, вивианит в свежем виде бесцветен, на воздухе приобретает синюю окраску, а при обжиге оранжево-желтую или темно-красную.

К минеральным пигментам относятся также киноварь, асфальт $u$ пиролюзит.

Большое количество пигментов получают искусственным путем. Пигменты используют для получения различных красок и лаков, в производстве линолеума, клеенки, пластмасс, резины, карандашей, в типографском деле, в бумажной промышленности, в производстве цветной штукатурки.

Основными техническими свойствами пигментов являются uвет, светостойкость, интенсивность (красящая сила), укрывистость, дисперсность, антикоррозийность, водоупорность, маслоемкость, атмосфероустойчивость, коэффиииент контрастности.

Светостойкость - способность сохранять постоянство окраски и оттенка под воздействием солнечного света.

Интенсивность - способность пигментов передавать свою окраску разбеливающему веществу. Обычно интенсивность выше у высокодисперсных пигментов, но при очень высокой дисперсности у большинства минеральных пигментов (охры, малахит, сиена) повышение красящей силы замедляется с увеличением степени дисперсности. Исключением является железный сурик.

Укрывистость - способность плотно покрывать первоначальный цвет окрашиваемого изделия.

Маслоемкость определяется количеством масла, необходимого для растирания 100 г пигмента до пастообразного состояния.

Среди месторождений минеральных пигментов установлены следующие генетические типы: 1) гидротермальный; 2) выветривания; 3) подземноводный; 
4) осадочный; 5) пирометаморфический; 6) метаморфогенный; 7) эффузивноосадочный.

К гидротермальным относятся формации: киноварная, баритовая и железооксидная, а также гидротермальных глинистых минералов (групп каолинита и монтмориллонита), талька, пирофиллита.

К формациям выветривания относятся месторождения первичных каолинов, оксидов и гидроксидов железа и марганца. В частности, примерами формаций, связанных с выветриванием эндогенных концентраций, являются формации железных охр и руд никеля в корах выветривания ультрамафитов, а также вермикулита, железной шляпы колчеданных месторождений, малахита и азурита, выветривания эффузивных пород. Характерными образованиями выветривания лав и пирокластов андезит-дацитового подтипа андезитовой вулканогенной формации являются, по В. С. Тарасенко, охры ВыгорлатГутинской вулканической гряды в Закарпатье.

К формациям, связанным с выветриванием экзогенных кониентраций, относятся формации зон выветривания залежей сидерита, пиритоносных глин, карбонатных руд марганца, окисленных углей. Более сложный (трехэтапный) генезис имеет формация зоны окисления силикатных марганцевых руд: осадконакопление, метаморфизм, выветривание. К переотложенным корам вылетривания относят формацию вторичных каолинов, а также переотложенных кор выветривания эффузивов (железооксидно-глинистые).

К подземноводной группе относят формацию волконскоита. Концентрации этого пигмента, согласно В. В. Александрову и Н. А. Игнатьеву, формируются при замещении погребенных стволов деревьев под воздействием подземных вод, обогащенных хромом. Для месторождений Пермской области в качестве источника хрома предполагаются ультрамафиты Уральской складчатой области. Скопления волконскоита окружены «ржавцом» - ржаво-бурой железистой «рубашкой», мощность которой достигает 0,5 м. Скопления волконскоита имеют столбообразную форму, залегают субгоризонтально, протяженность тел изменяется от нескольких сантиметров до 15 м.

К осадочным образованиям принадлежат месторождения железа, марганца, мела, глин, доломитов, мелоподобного мергеля, диатомитов, глауконита, вивианита и др. В последнее время вивианитовые накопления в торфяниках рассматривают не столько как источники пигментов, а как туковое сырье.

К пирометаморфическим относятся месторождения природной сажи, сформированные в результате пожаров на залежах каменных углей.

К метаморфогенной относятся месторождения глинистых сланцев, графита, талька, пирофиллита, красных мраморизованных известняков, 
железных руд. Среди железных руд в качестве пигментов используют не только собственно метаморфогенные месторождения, но и продукты их окисления (мартитовые руды).

\section{К метаморфической группе (контактово-метасоматический тип)} принадлежат месторождения лазурита, а к регионально-метаморфическомушунгита и пирофиллита. 


\section{6 НЕРУДНЫЕ ПРИРОДНЫЕ СТРОИТЕЛЬНЫЕ МАТЕРИАЛЫ}

Нерудные материалы являются осадочными породами, добычу которых осуществляют открытым способом в карьерах. К ним относят: глину, грунт, бетон, песок, щебень, керамзит, строительный камень, гранит, известняк и прочие вещества и минералы. Нерудные материалы классифицируют по нескольким показателям: плотные и пористые материаль, природные, а это гравий, песок, щебень.

Гравий, рыхлая горная порода, состоящая из скатанных обломков горных пород и минералов размером в поперечнике от 1 до 10 мм. По происхождению гравий разделяют на речной, озёрный, морской и ледниковый. Гравий применяется как строительный материал, в качестве крупного заполнителя для бетона, в дорожном строительстве.

Природный гравий - это натуральный материал, который формируется под влиянием ветра и разрушения горных пород. В зависимости от типа залегания, он может быть горным (или овражным), речным, озерным морским или даже ледниковым.

Под словом «гравий» может подразумеваться как естественный материал, так и искусственный (керамзитовый), произведенный промышленным путем. И природный, и керамзитовый гравий популярны среди строителей, изготовителей бетона, дизайнеров и других специалистов.

Обычно строители выбирают горный гравий, поскольку его технические качества несколько лучше, чем у других типов. Его используют для строительства трасс, фундаментов, засыпки разнообразных площадок, получения кровельных материалов. Гравий имеет различные оттенки: черные, желтые, белые, серо-голубые, коричневые, розовые. Его цвет может несколько меняться под влиянием освещения или влажности. Некоторые параметры гравий приобретает уже в процессе его подготовки и переработки (рассев, очистка, смешивание и т. д.). Подобная подготовка помогает получить довольно однородный по составу материал и добиться соответствия официальным нормам.

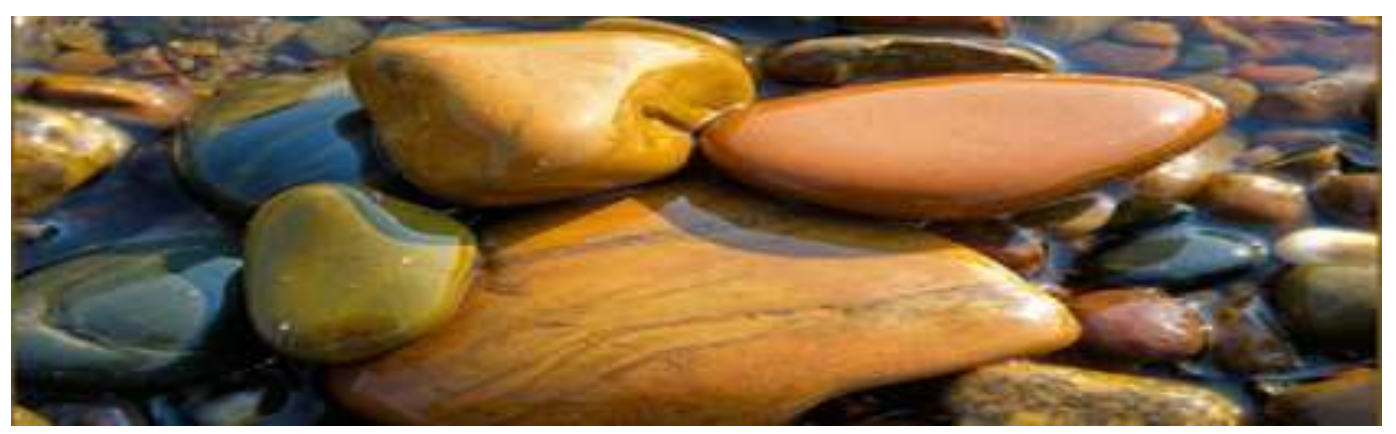

Рисунок 9. Гравий 
Сцементированный гравий называется гравелитом и обладает текстурами, присущими песчаным породам. Он широко распространен среди осадочных образований.

Наличие гравелита свидетельствует об интенсивном размыве древних толщ и указывает на близость суши, мелководья или поднятий, например, положительных форм рельефа дна бассейна.

Основные свойства природного гравия: плотность материала может колебаться в зависимости от его типа. Усредненный показатель плотности гравия - 2,6-2,7 т/м3. Насыпная плотность может иметь значение от 1,43 до 1,61 т/м3; объемный вес равен 1600 кг/м3, а удельный - 1400 кг/м3; форма зерен может быть округлой, округло-угловатой, угловатой.

Согласно ГОСТу 8267-93, в составе гравия может быть не больше 35\% (от массы) зерен, имеющих игловатую или пластинчатую форму; прочность материала выражается в марках по дробимости при раздавливании (или сжатии) в цилиндре.

Существуют такие марки по прочности: ДР8, ДР12, ДР16, ДР24. Предел прочности на сжатие равен 1,5 т/см2; для гравия, который используется в строительстве дорог, дополнительно устанавливают меру истираемости, которая определяется в результате испытаний в полочном барабане. При этом выделяют марки И-I, И-II, И-III и И-IV; исходя из степени морозостойкости, выделяют марки гравия от F15 до F400.

Щебень - это продукт дробления горных пород и искусственных каменных материалов. Щебень является остроугольным обломком горных пород размером до 100 мм, образовавшимся при их выветривании и встречающимся в виде рыхлых или слабо сцементированных скоплений.

Например, металлургических шлаков, кирпича, в виде кусков угловатой формы размером 5-150 мм. Применяется, в зависимости от их свойств, в качестве заполнителей бетонов, для балластировки железнодорожных путей, в строительстве автомобильных дорог, гидротехнических сооружений и т.д

Технические характеристики нерудных материалов являются уникальным и незаменимым природным компонентом в любом строительстве. Качественный строительный песок, речной песок, карьерный песок, известняковый щебень, гранитный щебень, позволяют выполнять строительные работы отличного качества и на самом высоком уровне.

Песок - осадочная горная порода, а также искусственный материал, состоящий из зёрен горных пород. Очень часто состоит из почти чистого минерала кварца (вещество - диоксид кремния). Широко используется в составе строительных материалов, для намывки участков под строительство, для пескоструйной обработки, при возведении дорог, насыпей, в жилищном 
строительстве для обратной засыпки, при благоустройстве дворовых территорий, при производстве раствора для кладки, штукатурных и фундаментных работ, используется для бетонного производства, в дорожном строительстве.

При производстве железобетонных изделий, бетона высоких марок прочности, а также при производстве тротуарной плитки, бордюров, колодезных колец используют крупнозернистый песок (Мк 2,2 - 2,5). Мелкий строительный песок используется для приготовления накрывочных растворов.

Речной строительный песок довольно широко применим в различных декоративных (смешивают с различными красителями для получения специальных структурных покрытий) и отделочных работах готового помещения. Строительный речной песок выступает компонентом асфальтобетонных смесей, которые используются в строительстве и укладке дорог (в том числе и для строительства аэродромов). Средней крупности песок можно добавить как заполнитель для бетонов или строительных растворов.

Строительный крупный песок часто применяют для строительства оснований и покрытий автодорог и аэродромов. Крупный песок используется при сооружении дренажей и септиков, так как песок фильтрует крупные частицы, содержащиеся в водяной смеси.

Строительный песок не образует смесей и не вступает в химические реакции с водой или вяжущими веществами, поэтому находит применение в растворах и бетонах, так как образуется скелет, который и уменьшает отвердение при усадке бетонов или растворов.

Кроме всего прочего, песок, используемый в строительных работах, отличается еще и по крупности. Так, есть крупные зерна песка, средние и мелкие, имеющие свое определенное значение.

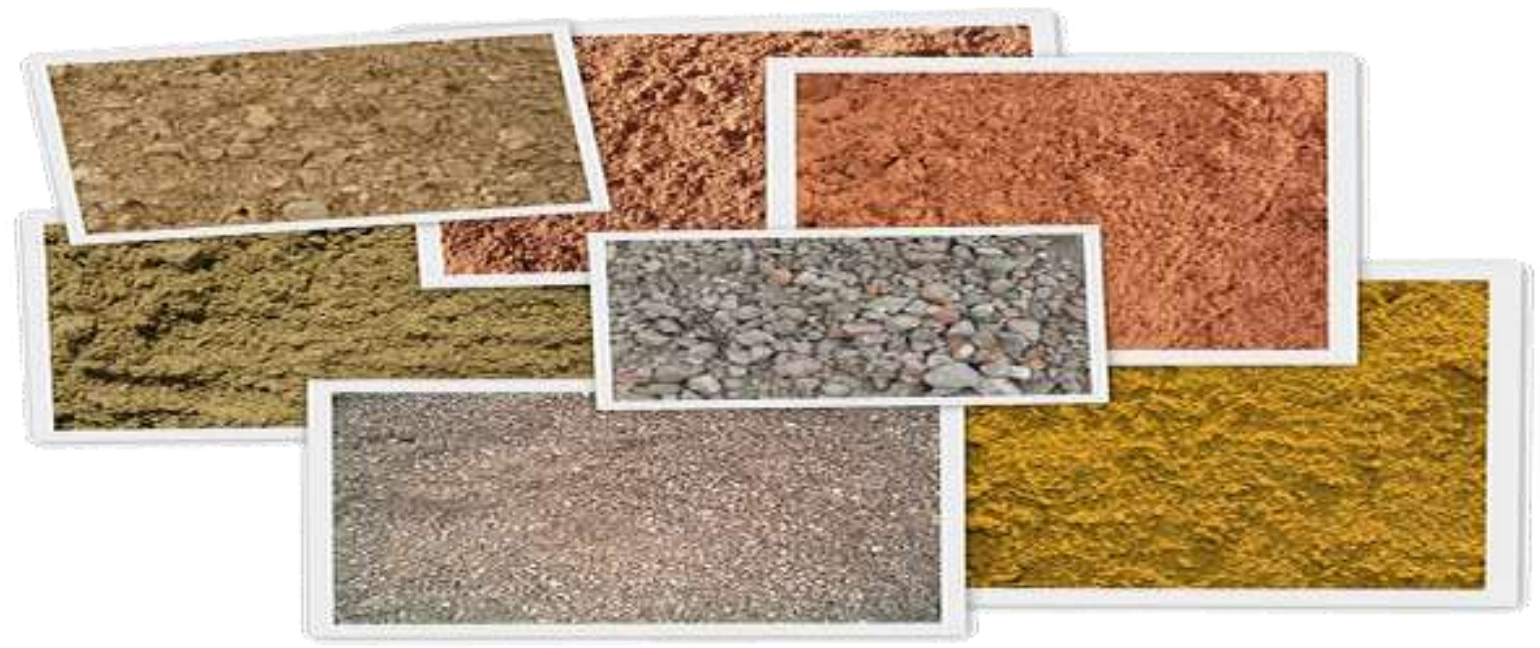

Рисунок 10. Строительные материалы 


\section{7 ПРИРОДНОЕ ДОРОЖНО-СТРОИТЕЛЬНОЕ МИНЕРАЛЬНОЕ CЫPbE}

Несмотря на технологическое развитие в производственном секторе, категория природных стройматериалов для укладки дорог является основной. Как правило, это продукция горнодобывающих предприятий, которая, в свою очередь, разделяется на магматические, осадочные и метаморфические материалы.

В основном используется сырье из обломочных и скальных пород, которые проходят основную переработку и могут использоваться в разных структурах дорожного полотна.

Наибольшей прочностью обладают скальные породы, поэтому их закладывают в ответственных технологических слоях.

Обломочные породы характеризуются рыхлой структурой и чаще используются как основа для цементобетонных и асфальтобетонных смесей.

К основным дорожно-строительным материалам каменной группы относят щебень, булыжник, шашку, высевки, брусчатку и т.д.

Также существуют классификации по степени обработанности и составу. В соответствии с первым признаком материалы разделяют на колотые, штучные и пиленые, а по составу - на простые (однородные) и сложные (агломераты).

Наиболее технологичным материалом данного рода считается цементный камень, формируемый в результате процессов кристаллизации продуктов гидратации и гидролиза. Благодаря кристаллическим отросткам, которые расходятся по всей структуре камня, обеспечивается высокая прочность как при армировании. Скорость обретения твердости определяется реакциями материала с клинкерными элементами и минералогическим составом цемента.

В условиях заводской обработки могут добавляться и пластификаторы для придания изделию дополнительных свойств. В основном используется сырье из обломочных и скальных пород, которые проходят основную переработку и могут использоваться в разных структурах дорожного полотна.

Наибольшей прочностью обладают скальные породы, поэтому их закладывают в ответственных технологических слоях. Обломочные породы характеризуются рыхлой структурой и чаще используются как основа для цементобетонных и асфальтобетонных смесей. К основным дорожностроительным материалам каменной группы относят щебень, булыжник, шашку, высевки, брусчатку и т.д. Также существуют классификации по степени обработанности и составу. 
В соответствии с первым признаком материалы разделяют на колотые, штучные и пиленые, а по составу - на простые (однородные) и сложные (агломераты). Наиболее технологичным материалом данного рода считается цементный камень, формируемый в результате процессов кристаллизации продуктов гидратации и гидролиза. Благодаря кристаллическим отросткам, которые расходятся по всей структуре камня, обеспечивается высокая прочность как при армировании. Скорость обретения твердости определяется реакциями материала с клинкерными элементами и минералогическим составом цемента. В условиях заводской обработки могут добавляться и пластификаторы для придания изделию дополнительных свойств.

\section{Рыхлые материалы и их классификация}

Это обширная группа дорожных материалов, которые образовывались в процессе выветривания твердых горных пород.

В результате эрозии и вымывания формируются мелкие элементы разной фракции, также характеризующиеся включением разных примесей и других инородных тел.

Для сортировки рыхлых продуктов выветривания по происхождению применяется следующая классификация дорожно-строительных материалов:

- водно-ледниковые или флювиогляциальные.

- Аллювиальные или речные.

- Эоловые или ветровые.

-Морские и озерные.

Различают такие материалы и по фракции:

- Baлуны. Грубоокатанные обломки горных пород в основном округлой формы фракцией от 150 мм.

- Галька. Для дорог преимущественно используется мелкая речная галька размером 5-20 мм.

- Гравий. Охватывает широкий размерный диапазон от 3 до 70 мм, но в основном к этой группе относятся рыхлые скопления обломков до 40 мм в диаметре.

-Песок. Зернистые элементы выветренных горных пород, фракция которых варьируется от 0,15 до 3 мм.

Грунтовые материалы - это неоднородные сыпучие материалы, которые в основном формируются несколькими видами минеральных частиц, к примеру, песком, глиной и пылеватыми включениями. Своего рода силовой каркас грунта образуют зерновые твердые элементы, которые касаются друг друга (порядка 7580\% общего состава), а промежутки заполняются пылеватой массой (15-20 \%). 
На долю глинистых элементов приходится 5-10\%. Существуют технологические нормативы, которые определяют оптимальное содержание компонентов грунта, а также виды элементов.

Грунтовый дорожно-строительный материал может быть и природным, и техническим. Оптимальные составы преимущественно имеют искусственное происхождение, а в условиях производства технологи могут также добавлять супеси, суглинок и другие добавки для оптимизации характеристик дорожностроительного состава.

Портландцемент как вяжущая основа для дорог: данный материал входит в группу гидравлических вяжущих компонентов, отвердевание которых происходит в воздушной или водной средах. Основу портландцемента составляет клинкерный помол с гипсовыми добавками в объеме 3-5 \%. Сам клинкер получается в процессе обжига тонкодисперсной смеси из глины и известняка.

В качестве модифицирующих добавок также могут вноситься смеси мергеля, доменного шлака, опока, нефелиновые отходы и т.д. Этот дорожностроительный материал может выпускаться в разных вариантах, которые имеют собственную маркировку 300, 400, 550 и др.

Данная цифра указывает на показатель активности, то есть величину прочности при изгибе. В дорожном строительстве практикуется использование практически всех марок портландцемента, каждая из которых выбирается из соображений целесообразности применения в конкретных условиях с учетом требований.

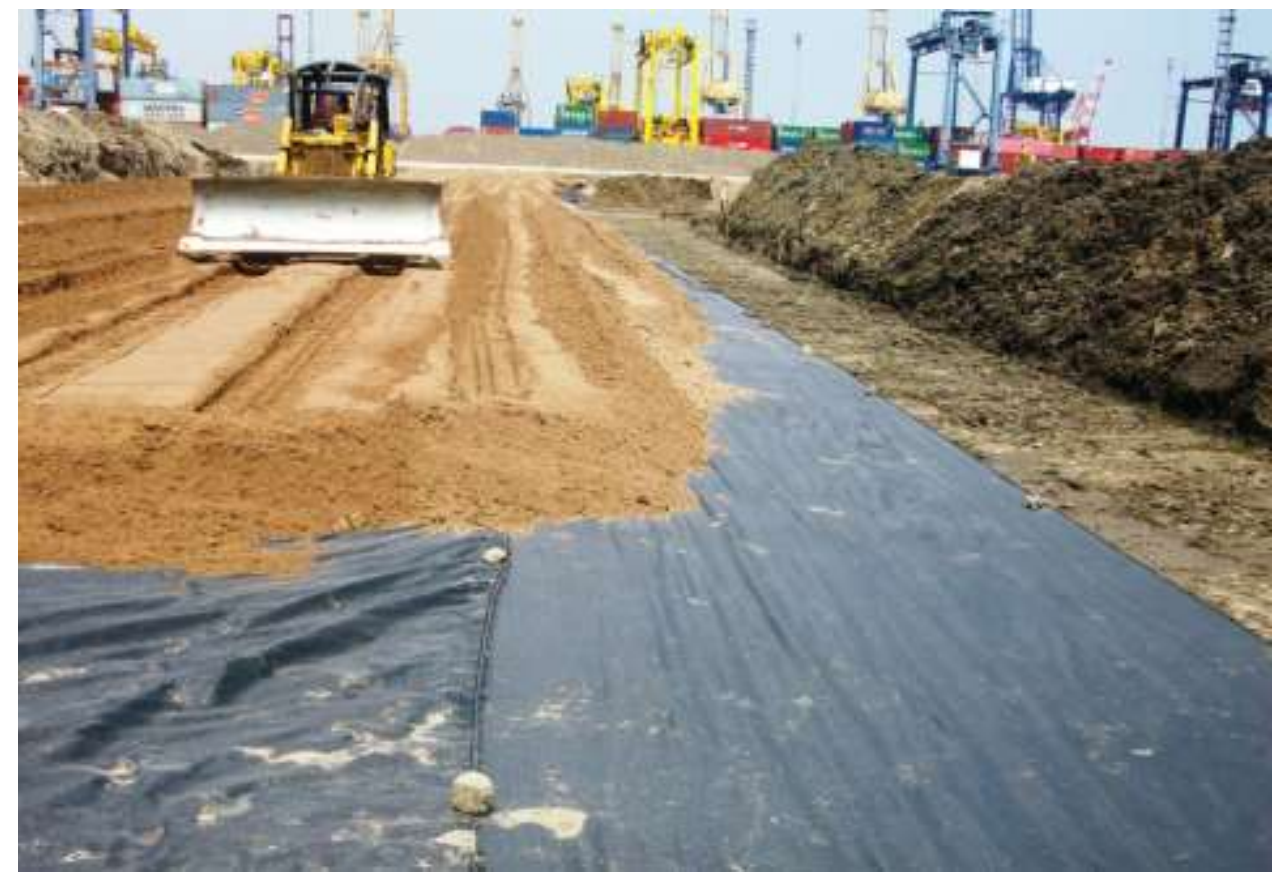

Рисунок 11. Дорожное сроительство 


\section{8 ПЕСЧАНЫЕ ПОРОДЫ}

В общем ряду осадочных образований песчаные породы представляют собой часть более обширного класса обломочных или терригенных, отложений, сложенных обломками горных пород и минералов, возникших преимущественно за счет механического разрушения существовавших ранее магматических, осадочных и метаморфических пород.

Физическое разрушение материнских пород и механическое перераспределение образовавшихся при этом обломочных продуктов является главным процессом, определяющим наиболее характерные черты осадочных пород. Генетическая классификация осадочных пород, предусматривает выделение трех классов осадочных пород:

- обломочные, в том числе эффузивно-обломочные, как продукты механического разрушения пород;

- глинистые, (глины), в том числе эффузивно-осадочные, как продукты химического разложения с примесью продуктов тонкого раздробления химическое преобразование терригенного материала, сопровождающееся возникновением новых соединений и минералов, в наибольшей степени химическим изменениям подвергаются частицы меньше $0,005 \mathrm{Mм}$, обладающие большой по сравнению с объемом поверхностью соприкосновения с окружающей средой

- породы химические и биохимические, в том числе эффузивно -осадочные, как продукты химического разложения и выпадения из растворов- прямое химическое осаждение веществ из истинных коллоидных растворов, осаждение веществ растворенных в воде, с помощью организмов-угли и битумы, как продукты фотосинтеза, - накопление продуктов фотосинтеза из газов атмосферы и воды в результате жизнедеятельности организмов,

- породы смешанные, в том числе эффузивно-осадочные, как продукты резкого смешения разного материала, накопление твердых продуктов вулканических извержений.

Если один из перечисленных процессов становится ведущим, происходит образование существенно глинистых осадков, химических, органических продуктов фотосинтеза или пирокластических отложений

Песчаные породы состоят из обломочных (аллотигенных) и аутигенных минералов.

Среди обломочных минералов породообразующими являются квари, полевые шпаты, слюды, глауконит, обломки горных пород.

Глауконит может быть обломочным (имеет такие же размеры зерен, как и другие обломочные минералы породы и несет следы окатанности) и аутигенным 
(слагает цемент породы или встречается в виде конкреционных образований микроконкреций).

Глауконитит - порода сложенная преимущественно из аутигенного глауконита.

Второстепенные и акцессорные минералы песчаных пород чаще всего представлены: магнетитом, ильменитом, цииконом, рутилом, гранатом, турмалином, апатитом, эпидотом, монациитом и др. Значительно реже встречаются: пироксены, амфиболь, дистен, силлиманит, корунд. Иногда они содержат золото, платину и некоторые драгоценные камни.

Аутигенные минералы слагают цемент песчаников. По минеральному составу цемент песчаников бывает глинистым (каолинит, гидрослюды и др.), карбонатным (кальцит, доломит, реже железистые карбонаты), кремнистым ( опал, халцедон, кварцин, кварц ), железистым ( окислы и гидроокислы железа). Значительно реже встречается цемент, состоящий из минералов группы хлорита, цеолитов, фосфатов, сульфатов.

Во многих песчаниках цемент полиминеральный: глинистокарбонатный, кремнисто - глинисто-карбонатный и т.п. Некоторые песчаники содержат зерна или стяжения сульфидов железа. Многие песчаники содержат примесь органического - углистого или битуминозного вещества.

По количеству и структуре цемента различают песчаники с базальнblм, поровыл и контактныл цементом.

По способу образования цемента - песчаники $c$ регенерационнылм (обрастание обломочных зерен тем же минералом с одинаковой оптической ориентировкой каемок), коррозионнылм ( цементация с частичным растворением обломочных зерен), кристификационнылм (обрастание зерен), пойкилитовыл (цемент состоит из крупных монокристаллов, в которых рассеяны обломочные зерна) и цементом механического выполнения пор.

В химическом отношении песчаные породы характеризуются высоким содержанием кремнезема, иногда повышенным количеством глинозема и железа.

По составу обломочного материала песчаники и алевролиты делятся на три группы:

- Мономинеральные - состоящие из одного минерала ( чаще всего кварияа ). Широко распространены кварцевые , сравнительно редко встречающиеся полевошпатовые и глауконитовые пески и песчаники.

- Олигомиктовые - из двух минералов ( чаще всего кварияа и полевого unama ). К ним относятся - кварцево-полевошпатовые, полевошпатово кварцевые, глауконитово-кварцевые, и др. 
В составе мономинеральных и многих олигомиктовых пород обычно преобладает квари - 80-99\%.

- Полимиктовые (поликомпонентные, полиминеральные) - из трех и более минералов ( чаще всего квариз, полевого шпата, слюды и некоторых др).

Точная диагностика таких пород производится под поляризационным микроскопом. В условиях буровой возможно отнесения их лишь к классу олигомиктовые, полимиктовые и мономинеральные

- Полимениральные разности представлены аркозами , грауваками и породами смешанного состава.

Аркозовыми песчаниками и аркозами называют песчаные породы, состоящие из кварияа, полевых шпатов и слюдыл.. Они представляют собой продукты разрушения гранитов и гнейсов. Содержание полевых шпатов в аркозах более 20\%,присутствуют также обломки пород (небольшое количество) и цемент, который обычно представлен гидрослюдой , каолинитом или карбонатами..

Граувакками первоначально называли песчаники, состоящие из обломков основных изверженных пород, имеющие крупный размер частиц и плохую сортировку материала. Такие представления сохранились у ряда современных авторов. Американские исследователи под граувакками понимают песчаники, содержащие, помимо кварца и полевых шпатов, значительное количество обломков горных пород, независимо от их состава, а также значительное количество глины. ( Вакки- несортированные глинистые песчаники.

Арениты - хорошо отсортированные песчаники, содержащие немного глинистых частиц меньше 10\%). Термин «граувакка» заметно эволюционировал, и в настоящее время под грауваккой понимают песчаники, содержащие кварц, полевые шпаты, слюды, обломки различных горных пород и цементирующее вещество. Обломков горных пород содержится не менее 20\%, цементом служит глина и продукты изменения обломочных зерен: серицит, хлорит, цеелиты и др.

Полевошпатовые граувакки или литоидные аркозы переходные породы между аркозами и граувакками.

Смешанного состава - песчаные породы, в составе которых все три компонента ( обломки пород, кварц и полевой шпат ) содержатся в количестве более 20\%, (аркозо-граувакки).

Структуры песчаных пород - nсаммитовые, nсаммо- nсефитовые, nсамоалевритовые, псаммо- пелитовые. В измененных и метаморфизо ванных песчаниках наблюдаются мозаичные конформно- регенерационные, стилолитовые, ииповидные и бластопсаммитовые структуры.

Текстуры - слоистые: косо- и диагонально-слоистые, волнистые $и$ горизонтально- слоистье. 
Цвет кварцевых песчаников - обычно светлые, белые, редко темные ( с магнетитом или органическим веществом), бурые и красно-бурые ( с железистым цементом ), полевошпатовые и аркозовые - розовые и красные, граувакковые - зеленовато - серые, темно - серые до черных; глауконитовые песчаники окрашены в зеленые тона.

Пылеватые породы - алевриты. Алевритовые породы очень сходны с песчаными. Основные различия заключаются в меньшем размере зерна, и, в связи с этим несколько ином минералогическом составе. В алевритах в больших количествах накапливаются глинистые минералы, слюды, и мало или нет обломков горных пород.

Алевролиты - плотные сцементированные породы. По внешнему виду и окраске они весьма разнообразны: серые, темно-серые, бурые, красные, зеленовато-серые, пестрые, часто тонкослоистые или плитчаты ( раскалываются на плитки), реже однородны, обычно переслаиваются с песчаными или глинистыми породами.

Глинистые породы - бывают как коллоидно-химического так $u$ хемогенного происхождения.

За верхнюю границу глинистых частиц, отделяющую их от собственно обломочных, условно принимают размер 0,01 или 0,005мм. Максимальная высота капиллярного поднятия до 10м при размере частиц менее $0,005 \mathrm{Mм}$, до $2 \mathrm{M}$ при размере частиц $0,005-0,05 \mathrm{Mm}, 0,13-1,05$ м при 0,05-1,0мм, 0,06 при размере частиц более 1 мм (коэффициент фильтрации соответственно 0,$001 ; 0,1 ; 2-50 ; 50$ 100 ; молекулярная влагоемкость \% 44,0; 10,$0 ; 4,0 ; 1,0$;

\section{1 Общая характеристика рыхлых пород. Песок}

Один из наиболее используемых горных пород- песок.

В земной коре, а также для других горных пород, т.е. необходимо знакомиться с понятиями:

- Запасы - это количество минерального сырья в недрах. Качество минерального сырья определяется содержанием в нем ценных и вредных компонентов.

- Категории: A+B+C 1 - промышленные; $\mathrm{C}_{2}$ - недостаточно изученные.

- Балансовые запасы - это такие запасы, добыча и переработка которых экономически целесообразна.

- Забалансовые запасы - это такие запасы, добыча и переработка которых экономически не целесообразна, но которые могут представлять промышленный интерес в будущем. 
- Прогнозные ресурсы - это потенциальные или возможные промышленные запасы. Они определяют целесообразность постановки поисковых работ. Подразделяются на три категории:

- Kamezория $\boldsymbol{P}_{\boldsymbol{1}}$ - вероятные запасы - прогнозные ресурсы известных промышленных месторождений, их флангов и глубоких горизонтов. Достоверность $\pm 70 \%$.

-Категория $\boldsymbol{P}_{2}$ - возможные запасы - прогнозные ресурсы месторождения рудопроявлений и точек минерализации, потенциальные перспективы которых определяются комплексом благоприятных признаков $( \pm 90 \%)$.

-Категория $\boldsymbol{P}_{3}$ - потенциальные ресурсы - прогнозные ресурсы рудоносных структур, оцениваемые по общим геологическим, геофизическим и металлогеническим критериям $( \pm 100 \%)$.

Качество минерального сырья характеризуется содержанием в нем ценных и вредных компонентов.

-Промышленные кондиции - учитывают минимальные запасы, содержание ценных компонентов и допустимое содержание в них примесей и другие данные. Эти показатели со временем изменяются

К этой группе горных пород обыкновенно относят песок и гравий, глину, растительную землю и всевозможные природные смеси этих вещееств,образующие то, что мы называем почвой.

Все они представляют собой продукты разрушения каменных пород, иногда с примесью органических остатков и состоят из отдельных частиц, между собою вовсе не связанных, или связанных очень слабо.

К гравийно-песчаным и песчаным относят рыхлые или слабо сцементированные горные породы, состоящие из окатанных в различной степени обломков горных пород и зерен минералов. Эти породы используют в качестве сырья для производства песка, гравия и щебня из гравия для строительных работ.

К песку относят обломки пород и зерна минералов размерами свыше 0,05 до 5 мм, к гравию - свыше 5 до 70 мм, к валунам - свыше 70 мм. Частицы размером до 0,05 мм считают пылевидными и глинистыми. Поддержанию песка, гравия и валунов выделяют следующие типы пород.

\section{- Песок, его характеристика, свойства и применение}

Песок представляет смесь зерен распавшейся от выветривания горной породы; так, например, при выветривании гранита образуется первоначально песок, содержащий зерна кварца, листочки слюды, глинистые частицы 
(получившиеся при распадении полевых шпатов), а также и не успевшие разрушиться гранитные зерна, состоящие из нескольких минералов.

Вода, перенося песок с возвышенностей на низменные места, округляет все эти зерна трением друг о друга и отмывает их, унося с собой наиболее мелкие частицы - глину. Таким образом, там, где скорость течения воды сразу замедляется, образуются отложения зерен, более или менее отсортированных водою по их величине и удельному весу, а, следовательно, и более разнородных.

Камень, искусственно разбитый на мелкие куски, называется щебнем.

По минералогическому составу чаще всего встречаются пески (горная порода) кваричевые, глауконито-кварцеевые, полевошпатово-кваричевые, слюдистье и другие.

Кварцевый песок - считается лучшим $\mathrm{SiO}_{2}$.

Крупность зёрен определяют последовательным просеиванием определённого количества песка через сита с разной крупностью ячеек. Обычно берут сита с ячейками 1,2 и 0,3 миллиметра. Пропускают 2кг песка. Если на первом сите осталось больше 1кг песка - то он считается крупным.

Если через сито с ячейками 0,5 миллиметра пройдёт свыше 1кг песка, то песок считается мелким.

Наличие примесей в песке.В горном песке всегда присутствуют примеси глины, в то время как в овражном - верхний слой загрязнён, а нижний, где песок промыт грунтовыми водами, чистый. Морской песок содержит соли и органические остатки. Речной песок - наиболее чистый.

Для оценки количества органических примесей взбалтывают песок с приблизительно равным по объему количеством 3\% раствора едкого натра и оставляют стоять сутки: если жидкость останется бесцветной или примет слегка желтоватую окраску - песок удовлетворителен; если же цвет жидкости будет темно-бурый, то песок непригоден ни для растворов, ни для бетонов.

Как песок, так и гравий несжимаемы и поэтому считаются надежным грунтом при устройстве основания.

Но если слой песка, притом мелкого, находится в области грунтовых вод, то при движении последних, например, в стенках рва в подобном грунте, он легко вымывается (так называемый плывун), против чего при постройках следует принимать необходимые меры.

Давление. Будучи помещен в вертикальный сосуд и нагружен чем-либо сверху, песок передает это давление почти целиком на стенки сосуда и лишь в малой степени на дно последнего. На этом свойстве песка основано применение песка для устройства песчаных свай, для забойки шпуров и т. п. 
Песок - фильтр. Вода просачивается через песок свободно, как бы ни был толст его слой; этим свойством пользуются при устройстве песчаных (английских) фильтров для очистки питьевой воды. По этой же причине песчаные местности всегда сухи.

\section{“Плывучесть".}

Наконец, еще одна особенность песка: рассыпаясь свободно, например, при осыпании какой-либо выветривающейся скалы, или стены выемки, сделанной в сыром песке, песок образует кучу, поверхность которой составляет с горизонтом довольно постоянный угол естественного откоса, обыкновенно около $45^{\circ}$.

Эта величина плывучести имеет значение, однако, только для слегка влажного песка; совершенно же сухой песок при лабораторных условиях образует гораздо меньший угол естественного откоса -- около $30^{\circ}$.

Для плывуна, т. е. мелкого песка, совершенно пропитанного водою, угла естественного откоса не существует, так как такой песок совершенно расплывается.

Все описанные свойства, характерные для чистого песка, теряются более или менее, когда песок содержит примеси глины и растительного перегноя.

При постройке и ремонте шоссейных дорог заготовляемый песок, гравий и щебень удобнее располагать вдоль дороги в виде конических куч, легко обмеряемых, благодаря указанному выше постоянству угла естественного откоса.

\section{Примеси, встречающиеся в песке, могут быть удалены:}

- Крупные механические примеси - камни, щепки и т. п. удаляются просеиванием. Для просеивания (грохотания) обыкновенно служит грохот.

- Мелкие примеси - глина и т. п. удаляются промыванием водою. Промывку песка можно производить, устроив лоток с текущей водой и перебрасывая песок лопатой, или перегребая его граблями навстречу течению воды. 


\section{9 БИТУМЫ}

Битум представляет собой продукт твердого или смолоподобного типа, в состав которого входит углеводород. Существуют различные типы битума: природный, искусственный или технический и нефтяной.

Природный битум. Если заглянуть в справочник, то можно узнать, что природным битумным материалом являются горючие ископаемые, точнее, их составная часть. Если конкретизировать, то, прежде всего, природные битумы это естественные производные нефти. Они могут образовываться, если консервация залежей была нарушена из-за окисления, биохимического или химического. Для того, чтобы добыть природное богатство из-под земли, обычно роют карьеры или шахты.

К природному битуму относятся асфальты, озокериты, мальты, то есть продукты, получаемые из горючих ископаемых.

Технический или искусственный битум. Технический или искусственный битум получается в результате переработки каменного угля, нефти и сланцев. Состав искусственных битумых материалов схож с составом природных битумов.

Нефтяной битум. Нефтяной битум широко используется в производстве рубероида, различных битумных мастик. Также данный тип битума нашел широкое применение в производстве всем известного асфальта и строительных растворов из асфальта

Пластичность, отличные характеристики даже при низких температурах и резких перепадах, устойчивость к деформачиям различного типа битума - все это делает нефтяные материалы просто незаменимыми при возведении дорог и зданий. Не случайно более $90 \%$ всего производимого битума используется при строительстве дорог. Этот факт легко объясняется тем, что именно нефтяной битум представляет собой довольно удобный и дешевый материал для обустройства дорожного полотна. Это подтверждено опытом разных стран.

Природные битумы - полезные ископаемые органического происхождения с первичной углеводородной основой. К ним относятся естественные производные нефти, образующиеся при нарушении консервации её залежей в результате химического и биохимического окисления или тектонических процессов. Их добычу проводят главным образом карьерным или шахтным способом (битуминозные пески).

По составу, зависящему от состава исходных нефтей и условий их преобразования, условно подразделяются на несколько классов:

- мальты;

- асфальты;

- асфальтены;

- кериты;

- озокериты;

- гуминокериты;

- ․траксолиты; 
- нафтиды;

- нафтоиды.

Битумы - широко распространённый и известный инженерностроительный материал, используемый в разных сферах:

- для устройства гидроизоляции в строительстве дорог, зданий и сооружений, прокладке трубопроводов;

- в производстве асфальтобетона;

- при изготовлении кровельных материалов;

- в лакокрасочной и кабельной промышленности;

- для заливочных аккумуляторных мастик и др.

Битумы обладают недостатками при использовании их в дорожном строительстве. К ним относятся:

- высокая термическая чувствительность (размягчение при высоких температурах и хрупкость при низких);

- плохие механические характеристики и низкая упругость;

склонность к старению (высыхание).

Для решения этой проблемы в дорожном строительстве используют «модифицированный битум. 


\section{0 ПРИРОДНЫЕ КАМНИ}

Камень, природный камень, натуральный камень- твёрдая неметаллическая горная порода, или её кусок, появившийся в результате дробления твердых горных пород.

По своей структуре, фактуре и составу они сильно отличаются друг от друга, а потому их видов чрезвычайно много.

Одни из них были образованы на суше, другие - под воздействием пресной или морской воды. Например, некоторые глыбы были сформированы благодаря моллюскам, которые умирая, опускались на дно, устилая его раковинами и панцирями.

Со временем слой становился толще, плотнее и через какое-то время разрушался, не выдерживая собственного веса, вследствие чего частицы раковин перемешивались и образовывали глыбы.

Натуральные камни, являют собой остатки:

- Разрушенных осадочных пород (75\%), которые были сформированы в результате различных эрозийных процессов, прежде всего - выветривания и разрушения горных пород, механического или физического выпадения из воды осадка, жизнедеятельности организмов.

Среди наиболее известных названий камней - известняк (природный камень белого цвета, состоящий из карбоната кальция), песчаник (состоит из частиц кварца) и мрамор - природный камень, который появился при преобразовании известняка и доломита;

- Метаморфических пород (около 20\%) - магматические и осадочные породы, что были образованы внутри планеты и изменились под влиянием различных физико-химических процессов, прежде всего, давления водных и газовых растворов и высокой температуры. Самый известный натуральный камень этого вида является кварцит, состоящий из слюды и кварца;

-Магматических пород, что были выброшены вулканами наружу из недр Земли. Самым известным видом является гранит - одна из наиболее твёрдых, прочных и плотных пород. Цвет этого камня чрезвычайно разнообразен: серый, красный, коричневый, зелёный.

Важнейшей характеристикой каменных природных материалов являются такие свойства, как их прочность и долговечность, то есть способность сохранять свои качества вне зависимости от внешнего воздействия. По этому показателю натуральные камни делят на:

- Высокодолговечные - начинают разрушаться через шестьсот лет, к ним относят кварциты и мелкозернистые граниты; 
- Долговечные - начинают крошиться через два столетия (крупнозерни стые граниты);

- Относительно долговечные - разрушение начинается через сто лет (белый мрамор, плотный известняк, доломиты);

-Недолговечные - рассыпаться начинают уже через четверть века (цветной мрамор, пористый известняк, гипс). Самые распространённые виды минералов и горных пород в виде строительных и отделочных камней:

- Гранит - природный камень магматического происхождения, который состоит из кварца, плагиоклаза, калиевого полевого шпата и слюд. Цветовая гамма: серый, красный, бордово-красный, красно-розовый, розовый, коричневокрасный, серо-зелёный, черно-зелёный с крупными светлыми вкраплениями.

Одна из самых плотных, твёрдых и прочных пород. Используется в строительстве в качестве облицовочного материала.

- Известняк - природный камень осадочного происхождения, белого цвета, состоящий из карбоната кальция (кальцита).

- Ракушечник - довольно пористая порода, состоящая из раковин моллюсков и их обломков, скрепленных известковым цементом. Ракушечники легко поддаются обработке режущим инструментом, а некоторые виды можно полировать (правда, без получения декоративного блеска) Ракушечники широко используются в качестве строительного материала для стен, а также для наружной и внутренней облицовки зданий.

Основу ракушечника составляют известковые породы. От происхождения и структуры известняка ракушечник делится на большое количество разновидностей. Бывает, что некоторые виды известняка оказываются сцементированными в ячейки и образуются из частиц раковин.

- Мрамор является самым популярным и элитным камнем среди натуральных камней.

- Кварцито-песчаник - натуральный камень, монолит осадочного происхождения, породообразующим минералом которого является кварц. Цветовая гамма: желтые, бежевые, серые природные оттенки с ярко выраженным рисунком.

- Песчаник - природный камень осадочного происхождения, состоящий в основном из частиц кварца. Цветовая гамма: желтые, желто-коричневые, серые, серо-зеленые природные оттенки.

- Кварцит - природный камень, который относится к метаморфическим горным породам, состоящим в основном из кварца и слюды. Цветовая гамма: серо-зелёные и желто-коричневые природные оттенки, с серебристыми вкраплениями слюды. 
- Сланец - обобщённое название различных горных пород с параллельной слоистостью и способностью расщепляться на отдельные пластины; природный камень темно-зелёного, серого, коричневого, жёлтого, красного и др. оттенков.

- Порфир - природный камень, который относится к мелкокристалли ческой магматической горной породе с крупными включениями кристаллов кварца. Цветовая гамма: темно-красные, коричневые природные оттенки, с черными вкраплениями.

- Доломит - природный камень осадочного происхождения, состоящий целиком из минерала доломита. Цветовая гамма: розовые, желтые природные оттенки.

- Оникс является декоративно-поделочным камнем. У этого камня необычная расцветка, красивые и тонкие полоски придают ему необычную красоту.

Природные камни обрабатываются по специальной технологии и принимают различные виды удобные для строительных работ, могут превратить в каменную крошку, в гальку и т.д.

Природный камень является одним из древнейших материалов, используемых людьми для строительства домов, мостов или облицовки фасадов. Благодаря красоте, прочности и долговечности природный камень может стать украшением дворцов, храмов, усадеб или обычных домов.

В современном строительстве чаще всего натуральные камни используют при внешней и внутренней облицовке зданий. Для внутренней облицовки используют специальные мраморные или гранитные обои. Сочетание мозаичных рисунков и узорчатых структур придают внешнему виду красоту и богатство. Природный камень износостоек, морозоустойчив и почти не впитывает влагу. 


\section{1 ПРОМЫШЛЕННОСТЬ СТРОИТЕЛЬНЫХ МАТЕРИАЛОВ}

КАЗАХСТАНА

Промышленность строительных материалов подразделяется на три основные группы:

1) добыча минерально-строительного сырья;

2) производство связывающих материалов;

3) изготовление бетонных и железобетонных конструкций и изделий, стеновых материалов для строительства различных объектов.

В промышленности используется такие строительные материалы как гипс, песок, асбест, гранит, мрамор, глина и др. они встречаются на территории всей республики.

Глина, асбест, гипс добываются в Северном, Южном, Центральном и Восточном Казахстане, высококачественная белая глина - в Акмолинской области, кварцевый песок - в Акмолинской и Павлодарской областях. Расположение Казахстана в центральной части Евразии дает возможность в перспективе начать строительство автомобильных дорог, имеющих международное значение.

В Казахстане создана мощная сырьевая база для промышленности строительных материалов. Разведаны многочисленные месторождения практически всех основных видов этого сырья.

Строительные материалы представлены месторождениями кирпичных глин, песчано-гравийных смесей, строчтельного камня, облицовочных и стеновых (пильных) камней, цементного (известняки, глинистые породы), керамзитового (глины, суглинки, аргиллиты), петрургического (базальты, диабазы, габбро) сырья, минеральных красок, ангидрита и гипса.

Казахстан полностью удовлетворяет собственные потребности в строительных материалах, обеспеченность ими достаточно высокая.

Казахстан располагает многочисленными месторождениями облицовочных, стеновых и пильных камней, представленными гранитами, габбро, туфами, мраморами, известняками - ракушечниками и др.

Разведанные месторождения облицовочных материалов представлены гранитами (Курдайское, Жельтауское, Межовское, Теректинское и др.), габбро (Топарское, Шарыктас, Катынадырское), амазонитами (Майколь ское, Золотоноша), порфиритами и туфами (Акбастауское, Архарлинское, Карлыгаш, Сарыбулакское), мраморами (Тасколь, Саяк, Комаровское, Теректинское и др.), известняками-ракушечниками (Жетыбайское, Жельтауское, Ералиевское и др.). 
Обеспеченность Казахстана облицовочными, стеновыми и пильными материалами высокая.

В Казахстане сырьевая база по производству керамзитового сырья удовлетворительная. Она представлена месторождениями легкоплавких глин, суглинков, аргиллитов, глинистых сланцев. Крупными месторождениями керамзитового сырья являются Дарабазинское, Алаботинское, Аденсу, Даниловское, Бузулукское и др.

Казахстан имеет значительные запасы петрургического сырья для организации камнелитейного производства.

Петрургическое сырье представлено базальтами, габбро-диабазами и другими породами, пригодными для производства изделий каменного литья и минеральной ваты.

Разведанными и наиболее крупными являются месторождения: Даубаба, Ташкурсайское, Ушкызыл, Дорменсай, Караузекское, Козыревское, Бедаревское и др.

Установлено, что волластонит месторождения Аксоран в Центральном Казахстане является сырьем, пригодным для получения минеральной ваты высокого качества. Запасы волластонита на этом месторождении оцениваются в 50 млн.т. 


\section{2 ЭКОЛОГИЧЕСКИЕ ПРОБЛЕМЫ ДОБЫЧИ СЫРЬЯ И ПРОИЗВОДСТВА СТРОИТЕЛЬНЫХ МАТЕРИАЛОВ}

При добыче и переработке полезных ископаемых происходит масштабное воздействие человека на природную среду. Возникающие при этом экологические проблемы, связанные с добычей полезных ископаемых, требуют всестороннего изучения и незамедлительного решения.

Предприятия добывающей промышленности стали крупнейшими источниками загрязнения природной среды. Вещества, которые выбрасываются горнодобывающим комплексом, оказывают губительное воздействие на экосистему. Проблемы негативного воздействия добывающей и перерабатывающей промышленностей стоят очень остро, так как затрагивают все сферы жизни.

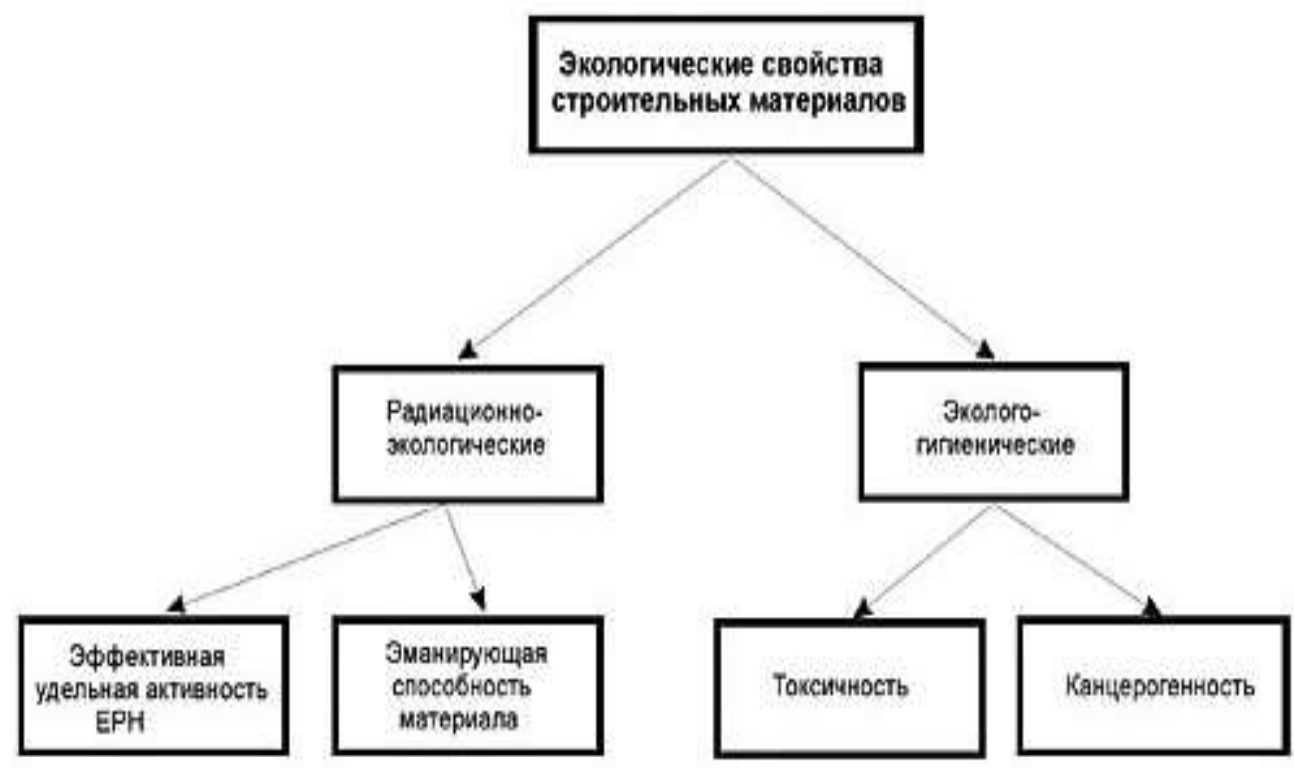

Рисунок 12. Экологические показатели негативного воздействия строительных материалов на окружающую среду

Масштабы развития добывающей отрасли поражают: при пересчете объемов добычи сырья на одного жителя планеты получится примерно 20 тонн ресурсов. Но лишь десятая часть из этого количества приходится на конечные продукты, а все остальное является отходами.

Развитие добывающего комплекса минерального сырья неминуемо ведет к негативным последствиям, основными из которых являются:

- истощение сырьевых ресурсов;

- загрязнение окружающей среды;

- нарушение естественных процессов. 
На современном этапе развития промышленных технологий необходимо предусматривать мероприятия по охране окружающей среды. В приоритете находится создание малоотходных или безотходных производств, способных значительно уменьшить губительное воздействие на экологию.

Чтобы сохранить природу, необходим комплексный подход к использованию отходов разработок и грамотное применение недр при добыче полезных ископаемых.

«Главная цель передовой технологии - отыскание способа производства полезного из бросового, бесполезного» Д.И. Менделеев.

При решении проблемы защиты окружающей среды важно использовать комплексные мероприятия: производственные, экономические, научнотехнические, социальные.

Улучшить экологическую ситуацию можно с помощью:

- более полного извлечения ископаемых из недр;

- комплексного использования всех компонентов пород;

- использования отходов в других производствах.

Во время добычи и переработки минерально-сырьевых ресурсов необходимо использовать современные технологии, позволяющие сократить выбросы вредных веществ. Несмотря на затратность применения передовых разработок, вложения оправданы улучшением экологической ситуации.

Одна из основных экологических проблем производства строительных материалов связана с громадными объёмами производства, добычей и переработкой свыше 2 млрд. т природных материалов. С этим связано широкомасштабное отчуждение, нарушение и загрязнение сельскохозяйст венных угодий, поскольку сырье для строительных материалов для уменьшения транспортных расходов, как правило, добывается как можно ближе к району строительства. А районы интенсивного строительства - это густонаселенные районы, удобные для выращивания сельскохозяйственных культур. Один из путей решения проблемы заключается в рекультивации нарушенных земель, устройстве прудов на месте карьеров и их использование для культурных иелей, рыборазведения и т.д.

Другой серьёзнейшей экологической проблемой предприятий строительной индустрии является значительное пылевыделение, особенно на заводах по производству цементов. Около 20\% производимого цемента выбрасывается в трубу, если не работает пылеочистка. Больше всего пыли выделяется с отходящими газами из вращающихся печей. Наряду с этим в больших количествах пыль выделяется при дроблении, сушке и помоле сырья (не только при производстве цемента, но также в производстве керамики, стекла и других строительных материалов), а также при охлаждении клинкера, при упаковке, в 
процессе погрузочно-разгрузочных работ на складах сырья, угля, клинкера и различных добавок.

Для снижения образования и выделения пыли, в первую очередь за счёт уменьшения неорганизованных выбросов, необходимо обеспечить полную герметизацию производственных агрегатов и транспортных средств и создать внутри аппаратов разрежение.

В качестве пылеулавливающих аппаратов на предприятиях по производству строительных материалов применяются все основные «сухие» методы очистки запылённых газов. От их технического состояния и уровня обслуживания в основном и зависит содержание пыли в воздухе производственных помещений и в атмосфере населённых мест.

Генеральным же направлением является использование в качестве сырья для промышленности строительных материалов отходов горнодобывающих и перерабатывающих отраслей.

По ориентировочным подсчётам в стране ежегодно образуется свыше 3 млрд. т горных отвалов, включающих все основные компоненты сырья, используемого в производстве стройматериалов.

Находят же применение лишь 6-7\%, причём большая часть - для планировки территорий, подсыпки дорог и в значительно меньшем объёме - для производства строительной керамики и других стройматериалов.

На предприятиях строительной индустрии используется значительное количество воды, которая расходуется непосредственно в технологических процессах.

Основными потребителями воды являются цементная промышленность и промышленность нерудных строительных материалов. На их долю приходится соответственно 34 и 29\% воды, используемой предприятиями промышленности строительных материалов.

Объём сточных вод, поступающих от предприятий промышленности строительных материалов в городскую канализацию и водоёмы, составляет около 650 млн. м³/год. В результате в водоёмы ежегодно поступает до 280 тыс. т солей, 28 тыс. т минеральных и 4 тыс. т органических веществ, высокотоксичные соединения шестивалентного хрома, фенолов, щелочей и нефтепродуктов.

Эколого-экономические факторы привели к необходимости разработки рациональных систем водопользования на предприятиях промышленности строительных материалов, в том числе к созданию замкнутых систем водного хозяйства.

В целом же промышленность строительных материалов не имеет принципиальных технических и технологических препятствий для организации своей деятельности по безотходной технологии. 


\section{3 СТРОИТЕЛЬНОЕ СЫРЬЕ АКТЮБИНСКОЙ ОБЛАСТИ}

В настоящее время первостепенное значение придается развитию регионального кластера «Строительные материалы», где ядром кластера выступают крупные и средние организации области, которые практически создали единую цепочку производства стройматериалов, начиная от добычи, отработки до выпуска и сбыта готового строительного материала.

На сегодняшний день в Актюбинской области разрабатывается только половина месторождений, богатых сырьём, на основе которого возможно производство строительных материалов. Между тем имеются запасы, из которых можно получать редкие качественные стройматериалы, производством которых занимаются лишь отдельные страны.

Количество резервных, не вовлечённых в разработку местных месторождений сегодня превалирует. Это говорит о недостаточном использовании сырьевой базы и создаёт предпосылки для её экстенсивного развития. К примеру, до настоящего времени не используются запасы каолиновых глин высокого качества для производства керамических изделий, кварцевого песка для производства листового стекла.

Одним из приоритетных направлений расширения сырьевой базы стройиндустрии считают вовлечение в производство отходов промышленности.

Пока этим занимаются только в отдельных фирмах. Например, активно используют отходы производства на Актюбинском заводе ферросплавов.

В ходе обширного анализа были также сделаны выводы, что структура отрасли имеет ярко выраженную сырьевую направленность. В области пока недостаточно предприятий, изготавливающих продукцию высокой степени переработки и соответствующую современным требованиям строительного комплекса.

Компании используют технологию, доставшуюся по наследству от Советского Союза, которые до сих пор применяют на кирпичных заводах, при производстве железобетонных изделий и при добыче нерудных материалов. Нет технологии производства химических и нефтехимических компонентов, важных для производства многих строительных материалов, которые по-прежнему импортируются и составляют значительную долю в себестоимости продукции.

Отдельные виды продукции являются неконкурентоспособными. Первую очередь планируется произвести модернизацию и переоснащение существующего технического парка, а затем организовать выпуск высококачественных строительных материалов, изделий и конструкций, способных вытеснить аналогичную импортную продукцию и быть конкурентоспособными на внешнем рынке. 
Для создания в области подобного кластера имеются все условия и предпосылки.

Во-первых, в соседних областях Казахстана и республиках СНГ, за исключением России, производство высокотехнологичных стройматериалов практически не налажено. К тому же Актюбинская область имеет выгодное географическое положение, соседствуя с регионами, в которых имеется дефицит в строительных материалах и подрядных организациях. Через область проходят автодороги республиканского значения и железнодорожные магистрали, в том числе Хромтау - Алтынсарино, которая связала область практически со всеми регионами Казахстана.

Во-вторых, имеется разнообразное и качественное сырьё, которое при умелом подходе, можно использовать для изготовления самого широкого ассортимента продукции.

В-третьих, уже развита сеть средних и мелких предприятий, которые имеют мощности для выпуска комплектующих изделий, необходимых в строительном комплексе. Имеются и крупные добывающие компании, которые инвестируют средства согласно заключенным соглашениям и меморандумам.

В большинстве районов Актюбинской области проблемой являются твердые бытовые отходы (ТБО) и строительные отходы (бесхозные строения).

Строительные отходы от разборки бесхозных жилых строений и животноводческих комплексов возможно применять:

- после «цивилизованной» разборки зданий отдельные их части (фундаменты, стены) или его отдельные конструкции повторно используются при малоэтажном строительстве, при этом территория после разборки зданий обязательно рекультивируется;

- некондиционные и поврежденные бетонные и железобетонные изделия, конструкции и изделия, отслужившие свой срок, полученные при демонтаже строительных объектов, отходы производства строительных материалов после переработки превращаются в строительный щебень вторичного происхождения по ГОСТ 25137-82 и арматурную сталь;

- строительный мусор можно использовать в качестве отсыпки автодорог местного значения, строительства небольших дамб, выравнивания ландшафта, засыпки карьеров.

Для каждого конкретного случая необходимо разрабатывать технические решения по сносу или проект сноса, при этом должны выполняться требования техники безопасности согласно СНиП РК 1.03-05-2001.

При разборке зданий будет наблюдаться пыление, в результате которого загрязняющие вещества попадут в атмосферный воздух. 
В районах размещения большого количества бесхозяйных строительных отходов рекомендуется строительство мини цехов (установок) по выпуску вторичного щебня.

Кроме того, необходимо максимально использовать мощности существующих на территории области щебеночных заводов. Например, строительные отходы п.Алабас Шалкарского района можно перерабатывать на местном щебеночном заводе.

Таким образом, не говоря о природном минеральном сырье, которые можно добывать, вторичные отходы (ТБО) могут создать дополнительный источник строительных материалов.

И, параллельно, решаются экологические проблемы, которые также являются немаловажной проблемой для региона. 


\section{ЗАКЛЮЧЕНИЕ}

Казахстан богат минерально-сырьевыми ресурсами, что позволило стране преодолеть сложный переходный период. Это будет способствовать динамичному развитию и в будущем. Добыча минерального сырья является составной частью экспорта страны. Продукция минерально-сырьевого комплекса составляет свыше $60 \%$ от общего объема промышленной продукции в республике.

Сегодня мировая экономика характеризуется неуклонным ростом потребления минеральных ресурсов и, соответственно, ростом цен на них. По прогнозам специалистов, при существующих темпах роста народонаселения и уровня потребления объемы используемого минерального сырья к 2050 году превысят достигнутый уровень минимум на 25\%, а по максимальным прогнозам - более чем на 50\%.

Борьба за источники дешевого сырья, а в целом за экономическое процветание и высокий жизненный уровень стран становится определяющим фактором как мировой экономики, так и геополитики.

В условиях жесткой международной конкуренции Президентом РК поставлена задача диверсификации отечественной экономики. Правительством определена Стратегия индустриально-инновационного развития Казахстана до 2020 года. Накопленные ранее и поступающие сейчас денежные средства от реализации сырьевых ресурсов необходимо эффективно использовать для осуществления этой программы и, в первую очередь, для развития новых технологий.

Можно отметить, что конец 20 века ознаменовался резким прорывом в познании глубинных недр Земли на базе хорошо организованных исследований, включающих сверхглубокое континентальное и океаническое бурение, драгирование океанического дна и его непосредственное изучение с помощью глубоководных аппаратов, а также инструментальные исследования с поверхности.

При этом проводится накопление принципиально новых данных на основе геологических и дистанционных методов, их обработка и увязка с имеющимися сведениями, теоретический анализ совокупности полученных данных и разработка концепций о строении и развитии Земли, реализация этих концепций в области прикладных исследований с целью поисков месторождений полезных ископаемых.

Проблема обеспечения промышленности минеральным сырьем со всей остротой встает уже в настоящее время. Основа нехватки минеральных ресурсов 
в том, что человечество берет из недр Земли во много раз больше, чем использует. Потери ценнейшего минерального сырья происходят при его добыче, обработке и транспортировке.

О масштабах потерь при добыче сырья можно судить по следующим показателям. Так, при шахтной добыче теряется от 20 до 40\% каменного угля, утрачивается от половины до двух третей добываемой нефти и еще больше строительного камня. При открытой добыче потери уменьшаются до 10\%.

Исходя из узковедомственных интересов, предприятия иногда извлекают из руд металлы, «профилированные» для своей отрасли, выбрасывая в отвалы все остальное, что приводит к порче месторождений, а то и безвозвратной потере разведанных запасов.

В результате возникает необходимость освоения новых месторождений, а значит, и дополнительных капиталовложений. В целом это ведет к истощению минерально-сырьевой базы. В шахтах и карьерах остается много руд, содержащих ценное сырье, вполне пригодное для его рентабельного использования. Это сырье безвозвратно теряется для людей.

Значительны потери и при обработке сырья. При обогащении руды перед выплавкой металла вместе с нерудными минералами в отвалы выбрасывается немало концентрата, содержащего металл. Кроме того, в отвал попадает много ценных включений, которые не всегда считают выгодным извлекать из руды.

Для решения проблемы обеспечения минеральным сырьем необходимы действенные меры по его охране. Охрана этого невозобновляющегося природного ресурса должна пойти по пути рационального, экономного использования, с тем чтобы его запасы в биосфере как можно дольше не истощались.

Для этого необходимо прежде всего свести до минимума потери сырья при его добыче, обработке и транспортировке.

Большое значение в сохранении месторождений полезных ископаемых имеет использование вторичного сырья, в частности металлолома. Так, 100 млн т металлолома позволяют сэкономить 200 млн т руды, 130 млн т угля, 40 млн т топлива. Среди мер охраны минерального сырья следует упомянуть его замену синтетическими материалами. Металлы с успехом заменяются пластмассами, и это направление сохранения сырья будет развиваться и дальше.

Для увеличения добычи и рентабельности переработки минеральных ресурсов, необходимо использовать современные средства и технологии.

Для успешного развития экономики страны необходима грамотная и целесообразная политика приведения этих ресурсов в целевое и рациональное использование, а также необходимость поддержания их экологического равновесия. 
Позитивный эффект в охране минеральных ресурсов может быть достигнут путем повышения мощности машин и оборудования при одновременном уменьшении их габаритов, металлоемкости, энергопотреблении и снижении стоимости на единицу конечного полезного продукта. Уменьшение металлоемкости и энергетических затрат - это одновременно и борьба за охрану недр. 


\section{ВОПРОСЫ ДЛЯ САМОПРОВЕРКИ}

1.Дайте определение термину «месторождение полезного ископаемого».

2. Что такое минеральное сырье?

3. Назовите виды полезных ископаемых.

4. Дайте определение термину «полезный компонент».

5. Что такое руда?

6.Природные каменные материалы

7. Минеральные (неорганические) вяжущие вещества

8.Характеристика вторичного сырья.

9. Виды вторичного минерального сырья.

10.Использование отходов металлургической промышленности в производстве цемента и других вяжущих материалов.

11. Глубинные породообразующие минералы магматических горных породи их физические свойства

12. Породообразующие минералы осадочных горных пород (группа кремнезема) и их свойства

13. Породообразующие минералы осадочных горных пород (группа глинистых) и их свойства

14. Разновидности метаморфических горных пород и их свойства 15. Отрасли промышленности - источники много тоннажных отходов.

16. Шлаки черной металлургии и области их применения.

17. Отвальные продукты цветной металлургии и области их применения.18.

Отходы горнодобывающей промышленности и области их применения. 19. Гипсовые отходы химической промышленности.

20. Отходы промышленности строительной индустрии и области их применения. 


\section{ТЕРМИНОЛОГИЧЕСКИЙ СЛОВАРЬ}

Аглопорит- искусственный строительный материал (заполнитель бетона) пористой структуры, в виде щебня или гравия, получаемый путём термической обработки шихты.

Адсорбция- поглощение газов, паров или жидкостей поверхностным слоем твердого тела (адсорбента) или жидкости.

Аргиллиты-это разновидность горной породы, он образуется в процессе высыхания и уплотнения глины.

Акцессорные минералы-это минералы, входящие в состав горных пород в очень малых количествах $(<1 \%)$, но являющиеся их закономерной частью; по характеру акцессорных минералов может быть установлено родство и происхождение горных пород.

Брекчии- это горная порода, состоящая из сцементированных угловатых каменных обломков.

Гажа- рыхлые отложения озерно- болотных водоемов, состоящие из углекислого кальция. Могут содержать примесь глины.

Конус Зегера- одноразовое изделие для измерения температуры от 600 до 2000 ${ }^{\circ} \mathrm{C}$, термоиндикатор.

Лесс - осадочная горная порода, неслоистая, однородная известковистая, суглинисто-супесчаная, имеет светло-жёлтый или палевый цвет. Однородные, обычно неслоистые, пористые, слегка сцементированные пылеватые отложения, сформировавшиеся преимущественно с помощью ветра.

Майолика (от итал. Maiolica - Мальорка) - разновидность керамики, изготавливаемой из обожжённой глины (отходов фаянса) с использованием расписной глазури

Петрургия- производство стеклокристаллических материалов и изделий (каменного литья) из расплавов горных пород

Терракота (от итал. terra - земля, глина и cotta - обожжённая) керамические неглазурованные изделия из цветной глины с пористым строением.

Шихта - совокупность материалов, подлежащих переработке данным заводским процессом. Смесь исходных материалов в определенных пропорциях, идущая в плавку в определенных пропорциях

Эфель-мелкие и легкие частицы горных пород, выносимые водой при промывке россыпного или при обработке рудного золота 


\section{ТЕСТОВЫЕ ВОПРОСЫ}

Кварцевый песок - это рыхлозернистый материал с размером частиц:
A. 5- 10 мM;
B. $0,05-0,16 \mathrm{~mm}$;
C. $0,16-5 \mathrm{MM}$
D. $0,05-3 \mathrm{MM}+$
E.10,0-100,0 Mм

Что называется, природными каменными материалами?
А. строительные материалы, получаемые из горных пород за счет применения механической обработки
В. природные агрегаты минералов
C. геологические тела, слагающие земную кору
D. смесь окатанных обломков горных пород, размером от 5-150мм.,
Е. сцементированная пористая горная порода, состоящая из раковин и их обломков,

Горные породы, состоящие из одного минерала называются .....
А. сложными
В. магматическими
C. метаморфические
D.осадочные
Е. простые+

Горные породы, состоящие из нескольких минералов называются .....
А. сложными +
В. магматическими
C. метаморфические
D.осадочные
Е. простые

«Минерал» с латинского языка переводится как ......
А. материал
В. руда +
C. горная порода
D. камень
Е. магма

Горные породы по генетическому происхождению классифицируются на:
А. магматические, излившиеся, видоизмененные
В. изверженные, обломочные, химические осадки
C. магматические, излившиеся, сцементированные
D. изверженные, вулканические осадки, органогенные 
Е. магматические, осадочные, метаморфические+

\section{Магматическими называют горные породы:}
А. образовавшиеся в условиях переотложения продуктов выветривания и разрушения различных горных пород
В. образовавшиеся при кристаллизации магмы на небольших глубинах в результате вулканической деятельности
C. образовавшиеся при застывании магмы на разной глубине в земной коре+
D. образовавшиеся под влиянием высоких температур идавлений
Е. возникающие в земной коре в результате физико-химических процессов

\section{Метаморфическими называют горные породы:}
А. образовавшиеся при кристаллизации магмы в результате вулканической деятельности
В. образовавшиеся при застывании магмы на разной глубине в земной коре
С. образовавшиеся в условиях переотложения продуктов выветривания и разрушения различных горных пород
D. образовавшиеся под влиянием высоких температур и давлений+
Е. возникающие в земной коре в результате физико-химических процессов

\section{Осадочными называют горные породы:}

А.образовавшиеся при застывании магмы на разной глубине в земной коре

В. образовавшиеся в условиях переотложения продуктов выветривания и разрушения различных горных пород+

C. образовавшиеся под влиянием высоких температур и давлений

D. образовавшиеся при кристаллизации магмы в результате вулканической деятельности

Е. возникающие в земной коре в результате физико-химических процессов

\section{К метаморфическим относятся породы:}
А. известняк, вулканический пепел
В.базальт, ракушечник
С.гранит, сиенит
D. мрамор, гнейсы +
Е. гипс, глина

К осадочным горным породам относится:
А. гнейс
В. мрамор 

C. габбро
D. базальт
Е. глина +

Породообразующие минералы магматических пород:
А. слюда, кварц +
В. глинозем, опока
C. гипс, роговая обманка
D. ангидрит, каолинит
E. магнезит, серпентин

\section{Породообразующие минералы осадочных пород:}
А. слюда, магнезит, опал, кремнезем
В. кварц, полевой шпат, слюда, роговая обманка
C. гипс, кварц, кальцит, каолинит+
D. силикат, плавиковый шпат, флюорит, гипс
Е. анортит, лабрадорит, доломит, кварц

\section{Плотные и водостойкие горные породы:}
А. брекчия, ангидрит
В. гранит, сиенит +
С. доломит, трепел
D.гипс, глина
Е.пемзы, туфы.

Абразивной обработкой камня получают фактуру:
А. фактуру «скалы», точечную, лощеную
В.пиленую, рифленую, бороздчатую
C. шлифованную, лощеную, полированную+
D. колотую, тесаную, рифленую
Е. различные виды грубообработанной фактуры

По способу изготовления природные каменные материалы делятся на:
А. пиленые и колотые+
В. фрезерованные и колотые
C. пиленые и шлифованные
D. шлифованные и полированные
E. абразивные и рифленые 


\section{Литые каменные изделия получают:}
А. из гипса и ангидрита
В. из сплава стекла и глины
С. из бетонной смеси и заполнителя
D. из базальта, известняка +
Е. из мрамора

Какое минеральное вяжущее не дает усадки при твердении:
А. строительный гипс+
В. портландцемент
C. быстротвердеющий цемент
D. воздушная известь
Е. глина

Какая группа горных пород применяется в тяжелых бетонах в качестве заполнителя:
А. гранит, трепел, магнезит, керамзит
В. гранит, пемза, туф, песчаник
C. гранит, диатомит, кварцит
D. гранит, керамзит, диорит, диатомит +
Е. гранит, диорит, габбро, базальт

Асбест - природный тонковолокнистый минерал, состоящий водных или безводных.
А.карбонатов кальция и магния
В.сульфатов кальция, калия и натрия
C. алюмосиликатов
D. органических остатков животного и растительного происхождения
Е.силикатов магния, кальция и натрия +

\section{Марку битума определяют:}
А. твердостью и растяжимостью
В. твердостью, температурой размягчения и растяжимостью+
С. химической стойкостью и температурой размягчения
D. растворимостью в органических растворителях и деформативностью
Е. водостойкостью, способностью размягчаться и сопротивляемостью действию щелочей 


\section{Плотные и водостойкие горные породы:}
А. брекчия, ангидрит
В. гранит, сиенит +
С.доломит, трепел
D. гипс, глина
Е.пемзы, туфы.

Абразивной обработкой камня получают фактуру:
А. фактуру «скалы», точечную, лощеную
В. пиленую, рифленую, бороздчатую
C. шлифованную, лощеную, полированную+
D.колотую, тесаную, рифленую
Е. различные виды грубообработанной фактуры

По способу изготовления природные каменные материалы и изделия можно разделить на:
А. пиленые и колотые+
В. фрезерованные и колотые
C. пиленые и шлифованные
D. шлифованные и полированные
Е.абразивные и рифленые

\section{Керамическими называют:}

А.искусственные каменные изделия, получающие необходимую прочность в результате затвердевания вяжущих

В.изделия, получаемые из минерального сырья путем придания им камнеподобных свойств посредством обжига при высоких температурах + С. изделия, получаемые из жесткой смеси кварцевого песка, извести и воды путем прессования под давлением и последующего твердения в автоклаве D. изделия, получаемые из минеральных силикатных расплавов

Е. искусственные каменные материалы, получаемые прессованием под вакуумом глины с последующим обжигом

К эффективным относят стеновые керамические изделия:
А. с невысокой стоимостью
В.с высокими показателями прочности и морозостойкости
С.плотной структуры
D. малогабаритные изделия
Е. пористые, пористо-пустотелые, пустотелые+

Укажите неверную форму минералов:

А. твердая 

В. плазма +
C. мягкая
D.пластичная
Е. вязкая

\section{Пигментами называются:}
А. тонкоизмельченные минеральные вещества
В. тонкоизмельченные органические вещества
C. тонкоизмельченные минеральные и органические вещества+
D.любое красящее вещество
Е. все ответы верные

\section{От чего зависят свойства минералов:}
А.строение +
Б. плотность
B.возраст
D. вязкость
E. Macca

Какие горные породы и в каком виде применяются для изготовления асфальтобетонов?
А. горные породы, предварительно подвергнутые механической обработке или без обработки: щебень, гравий, песок, бутовый камень, шашка и брусчатка;+ В. магматические горные породы без обработки;
C. метаморфические горные породы;
D. изверженные горные породы;
Е. глубинные горные породы.

\section{Минералы - это материалы,...}

А. полученные путем механической обработки природных каменных материалов без изменения их свойств;

В. более или менее постоянного состава природных агрегатов;

C. из природных тел однородные по химическому составу;

D. из природных тел однородных по физическим свойствам;

Е. из однородных по химическому составу и физическим свойствам природного тела.+

\section{Научное название шкалы твердости материалов?}
А. шкала Фаренгейта
В. шкала Рихтера
C. шкала Moоca +
D. шкала Бофорта
Е.шкала Цельсия 


\section{СПИСОК ЛИТЕРАТУРЫ:}

1. Борзунов В.М., Григорович М.Б., Гроховский Л.М., Нечаев Г.А., Сыромятников В.А. Поиски и разведка месторождений минерального сырья для промышленности строительных материалов. Недра, Москва, 1977 г., 248 стр.,

2. Никитин Г.М. Комплексное использование минерального сырья. - Павлодар: Павлодарский центр научно-технической информации, 2007. 29 с. 3 Равич Б.М. Комплексное использование сырья и отходов / Б.М. Равич, В.П. Окладников. - М.: Химия, $1988 . \quad-\quad 320$ с. 4. Абжаров А.А. Комплексное использование низкокачественного глиноземсодержащего сырья Казахстана. - Алма-Ата: Гылым, 1988. - 178 с. 5. Абдулиева А.А. Техногенное минеральное сырье рудных месторождений Казахстана / под ред. проф. А.А. Абдулиева. - Алматы: Институт геологических наук, 2002. - $122 \mathrm{c}$.

6 Козин В.3. Опробование минерального сырья. Научная монография

Издательство УГГУ, Екатеринбург, 2011 г., 316 стр., УДК: 622.709 (075.8), ISBN: 978-5-8019-0268-5

7.Высоцкий Э.А., Губин В.Н., Гуринович А.И., Илькевич Г.И., Ярцев В.И. Поиски и разведка месторождений минерального строительного сырья. Учебное пособие .БГУ, Минск, 2001 г., 120 стр.,

8. Петрова, Л. В. Химия вяжущих строительных материалов : учебное пособие / Л. В. Петрова, Е. С. Гиматова. - Ульяновск : УлГТУ, 1999; 2002. - 67 с.

9. Шмитько Е.И. и др. Химия цемента и вяжущих веществ: Учебник. - СПб: Проспект науки, 2006. - 206c.

10. Таймасов Б.Т. Химическая технология вяжущих материалов: Учебник. Шымкент: ЮКГУ им. М.Ауэзова, 2014. - 444c.

11. Дворкин Л.И., Дворкин О.Л. Строительные материалы из отходов промышленности. - Ростов н/Д: Феникс, 2007. - 368c.

12. Русина В.В. Минеральные вяжущие вещества на основе многотоннажных промышленных отходов. Учебное пособие. - Братск ГОУ ВПО «БрГУ», 2007.$224 \mathrm{c}$.

13. Мчедлов - Петросян, О. П. Химия неорганических строительных материалов / О. П. Мчедлов-Петросян. - М. : Стройиздат, 1988.

14. Наназашвили, И. Х. Строительные материалы, изделия и конструкции : справочник / И. Х. Наназашвили. - М. : Высшая школа, 1990. - 495 с.

15. Общий курс строительных материалов : учебное пособие для строит. спец. Вузов / И. А. Рыбьев, Т. И. Арефьева, Н. С. Баскаков, Е. П. Казенова, Б. Д. Коровников. - М. : Высшая школа, 1987. - 584 с.

16 Лугинина И.Я. Химия и химическая технология неорганических вяжущих веществ. В 2ч. - Белгород: Изд-во БГТУ им. В.Г.Шухова, 2004. - Ч.1. - 240с., Ч.2. $-199 \mathrm{c}$.

17. Инвестиционная и строительная деятельность в Актюбинской области // Статистический сборник. - Астана, 2014 г 


\section{ПРИЛОЖЕНИЯ}

А. ШКАЛА ТВЕРДОСТИ МИНЕРАЛОВ

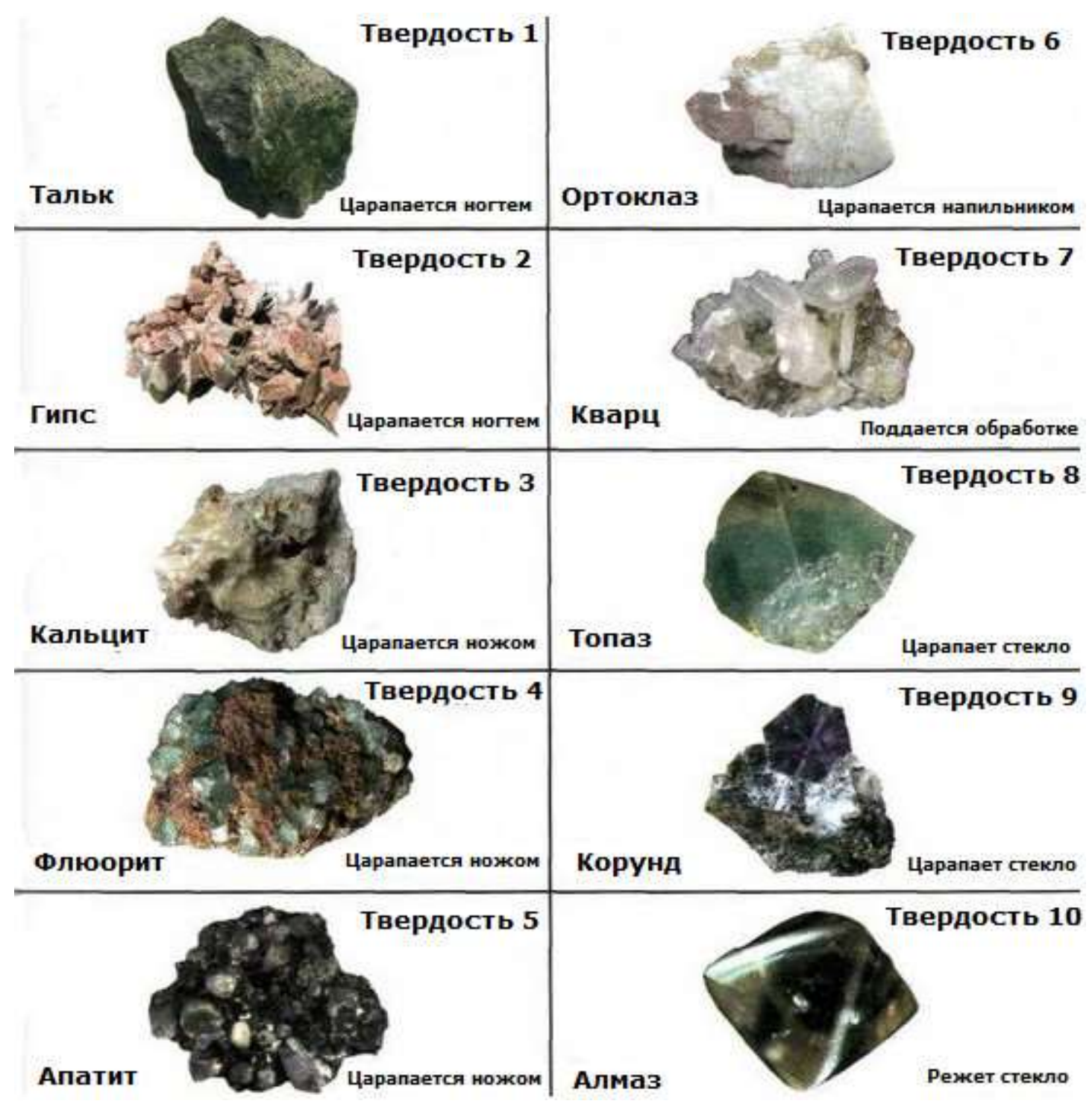




\section{Б. КЛАССИФИКАЦИЯ ГОРНЫХ ПОРОД И ИХ УСЛОВНЫЕ ОБОЗНАЧЕНИЯ НА ЧЕРТЕЖАХ}

Осадочные горные породы

Обломочные

Рыхлые

$$
\begin{aligned}
& \Delta^{D} \Delta^{\Delta} \\
& 0^{0} \sigma_{0}
\end{aligned}
$$

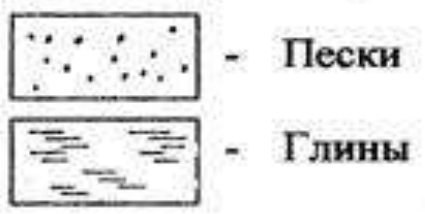

$$
{ }^{A} P r-\text { Гипс }
$$

\section{Сульфатно - галогенные}

$$
\begin{aligned}
& \nabla^{\nabla} \nabla_{\nabla}^{\nabla} \text { - Брекчии } \\
& \begin{array}{lll}
0 & 0 & 0 \\
0 & 0 & 0
\end{array} \text { - Конгломераты } \\
& \because \ldots \ldots \ldots \text { - Песчаники } \\
& \overline{\underline{-}} \overline{-}-\overline{-} \text { - Аргичлиты }
\end{aligned}
$$

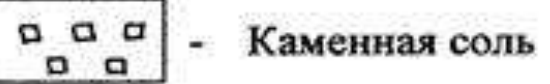

\section{Карбонатные}

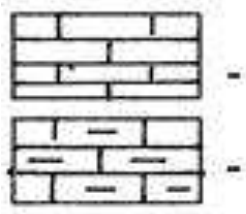

Известняки

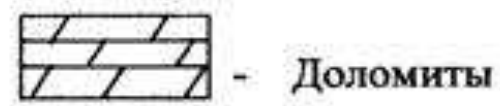

Мергели известковые

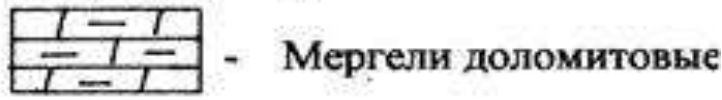

Магматическне горные породы

Вулканические
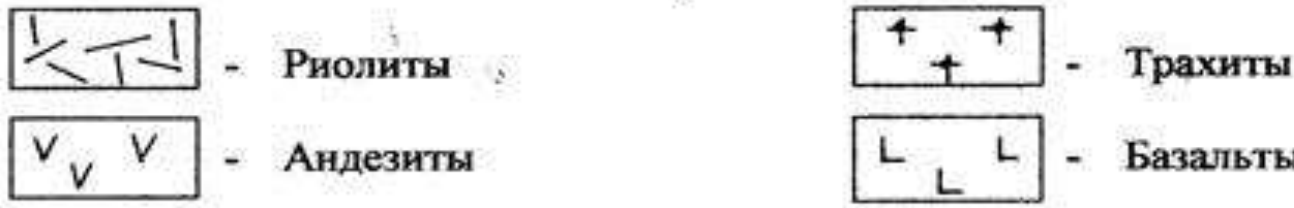

$L$ L - Базальты

Вулканогенно - осадочные

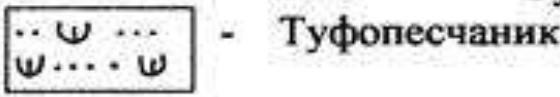

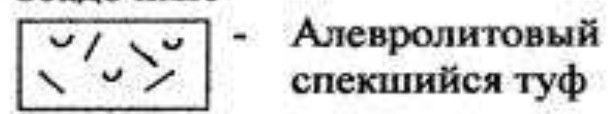

Интрузивные

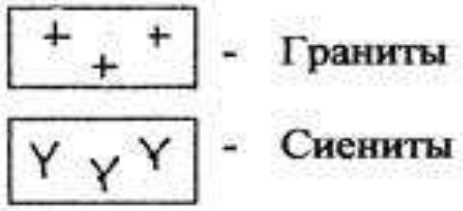

$\because: \because: \vdots \vdots$ - Кварииты

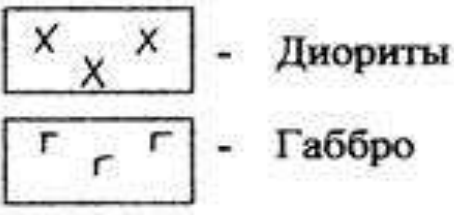

Метаморфические

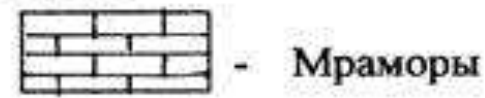




\section{В.УСЛОВНЫЕ ОБОЗНАЧЕНИЯ МИНЕРАЛОВ ДЛЯ ГЕОЛОГО - ЛИТОЛОГИЧЕСКИХ РАЗРЕЗОВ}

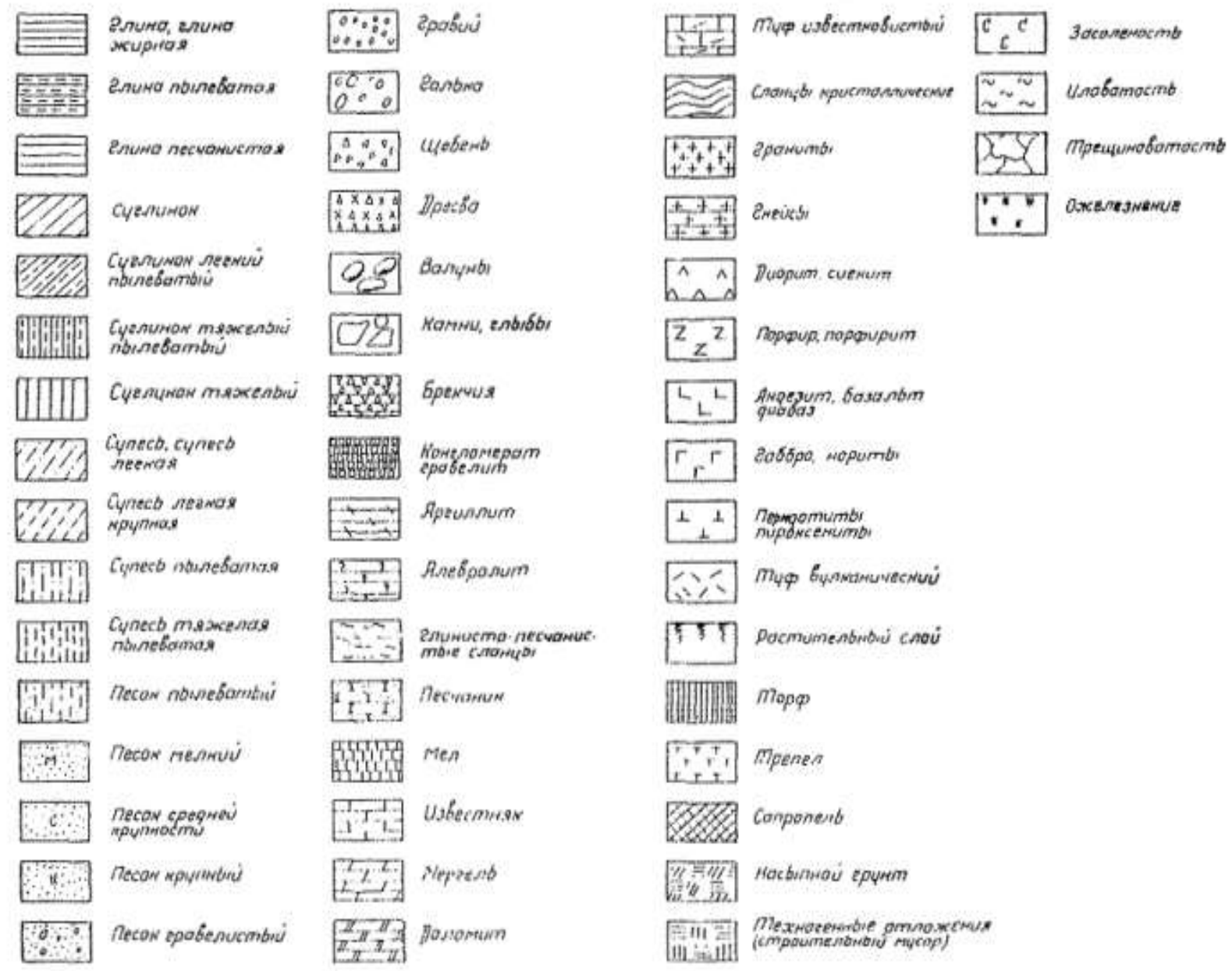

